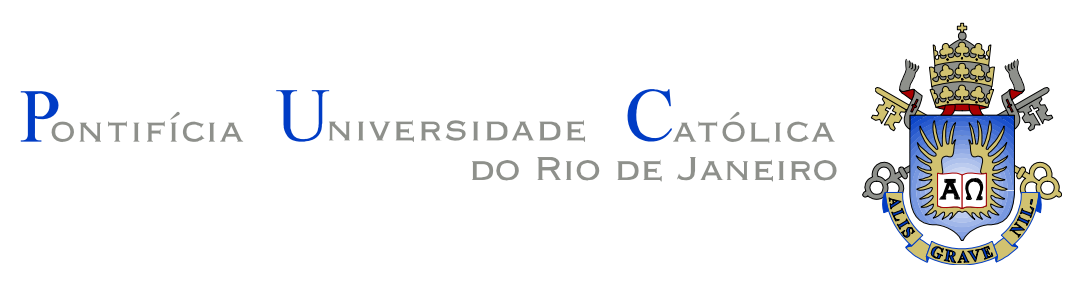

Jayro Alves Soares

O Kerygma no mundo fragmentado:

Uma leitura a partir de Jürgen Moltmann

Dissertação apresentada ao Programa de Pósgraduação em Teologia da PUC-Rio como requisito parcial para obtenção do título de Mestre em Teologia.

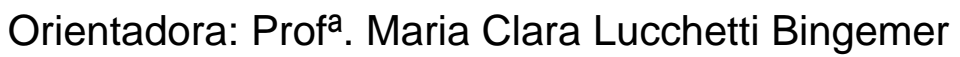




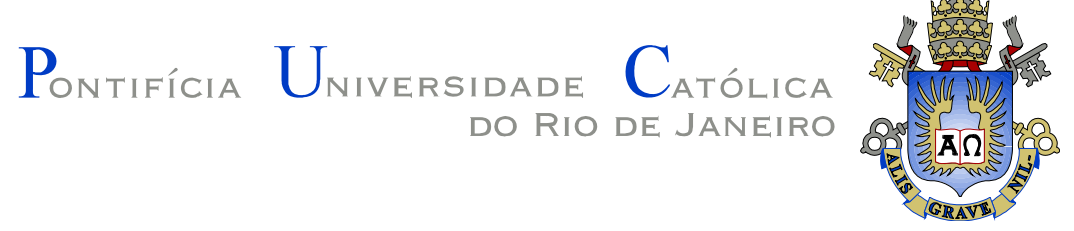

Jayro Alves Soares

\section{O Kerygma no mundo fragmentado: Uma leitura a partir de Jürgen Moltmann}

Dissertação apresentada como requisito parcial para obtenção do grau de Mestre pelo Programa de PósGraduação em Teologia do Departamento de Teologia do Centro de Teologia e Ciências Humanas da PUC-Rio. Aprovada pela Comissão Examinadora abaixo assinada.

Prof ${ }^{a}$. Maria Clara Lucchetti Bingemer

Orientadora

Departamento de Teologia - PUC-Rio

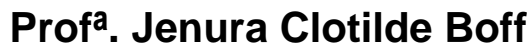

Departamento de Teologia - PUC-Rio

Prof. Josias da Costa Júnior

Instituto Metodista Bennett

Prof $^{a}$. Denise Berruezo Portinari Coordenadora Setorial de Pós-Graduação e Pesquisa do Centro de Teologia e Ciências

Humanas - PUC-Rio

Rio de Janeiro, 21 de março de 2013 
Todos os direitos reservados. É proibida a reprodução total ou parcial do trabalho sem autorização da universidade, do autor e da orientadora.

\section{Jayro Alves Soares}

Pastor presbiteriano. Graduou-se em Teologia pela Universidade Presbiteriana Mackenzie em 2008. É professor de Teologia Sistemática, Homilética e Hermenêutica no Seminário Teológico Escola de Pastores em Niterói.

Ficha Catalográfica

Soares, Jayro Alves

O kerygma no mundo fragmentado: uma leitura a partir de Jürgen Moltmann / Jayro Alves Soares; orientador: Maria Clara Lucchetti Bingemer. - 2013.

$118 \mathrm{f.} \mathrm{;} 30 \mathrm{~cm}$

Dissertação (mestrado)- Pontifícia Universidade Católica do Rio de Janeiro, Departamento de Teologia, 2013.

Inclui bibliografia

1. Teologia - Teses. 2. Pós-modernidade. 3. Kerygma. 4. Ser humano. 5. Cristologia. 6. Eclesiologia. I. Bingemer, Maria Clara Lucchetti. II. Pontifícia Universidade Católica do Rio de Janeiro. Departamento de Teologia. III. Título. 


\section{Agradecimentos}

À Deus, fonte da verdadeira sabedoria e conhecimento, Senhor da minha existência.

À minha orientadora, Dra Maria Clara Lucchetti Bingemer, pelo constante e gracioso acompanhamento nessa jornada. Sua competência e dedicação ao exercício da docência teológica inspiraram-me à concretização desse trabalho.

Aos professores do departamento de teologia da PUC - RJ, pela sua singular contribuição em minha formação acadêmica.

À CAPES, pela bolsa de estudos e pesquisa concedida durante o curso.

Aos meus Pais: Maria e Jayro (in memoriam) pelo investimento de vida que fizeram a esse filho. Quanto amor me deram!

À minha querida família. Josi, minha linda esposa e companheira de todos os momentos e meus maravilhosos filhos, Josué, Joyce e Jean. Não teria conseguido chegar até aqui sem o seu apoio. Vocês foram um bálsamo nos momentos mais difíceis da minha caminhada. Amo muito vocês!

À Luciana, irmã e amiga sincera de todas as horas.

Aos amigos e companheiros de jornada, Márcio, Rodrigo e Irênio. Como foi importante a sua presença ao meu lado!

À Igreja Presbiteriana de Trindade e sua Congregação em Fazenda dos Mineiros, por seu carinhoso apoio.

Ao Seminário Teológico Escola de Pastores, na pessoa do seu Diretor, Dr. Luís Vanderley Vasconcelos de Lima. Sempre serei grato pelo seu incentivo. 


\section{Resumo}

Soares, Jayro Alves; Bingemer, Maria Clara Lucchetti. O Kerygma no mundo fragmentado: uma leitura a partir de Jürgen Moltmann. Rio de Janeiro, 2013. 118p. Dissertação de Mestrado - Departamento de Teologia, Pontifícia Universidade Católica do Rio de Janeiro.

Esta pesquisa centra-se no estudo do tema do Kerygma no mundo fragmentado. Busca-se desenvolver o tema a partir da visão do teólogo alemão Jürgen Moltmann. A referida pesquisa visa a interação entre a leitura do Kerygma em Moltmann e suas propostas pastorais às demandas do ser humano pósmoderno. O trabalho se desenvolve em três capítulos que buscam estruturar esta dissertação: no primeiro, descreve-se o declínio da modernidade e o consequente nascimento da pós-modernidade, bem como a configuração existencial do ser humano pós-moderno; no segundo, desenvolve-se a leitura teológica do Kerygma bíblico em Jürgen Moltmann e no terceiro, retomam-se os principais pontos das reflexões dos capítulos anteriores com objetivo de fornecer propostas pastorais kerygmáticas às demandas do ser humano hodierno. A leitura kerygmática do referido teólogo propõe um comparecimento pastoral veiculado através de uma linguagem existencial e relacional, uma cristologia do caminho, materializando ortodoxia em concreta proclamação de vida coerente à situação existencial do ser humano de nossa época.

\section{Palavras-chave}

Pós-modernidade; Kerygma; Ser humano; Cristologia; Eclesiologia. 


\section{Abstract}

Soares, Jayro Alves; Maria Clara Lucchetti Bingemer (Advisor). The Kerygma in the fragmented world: a reading from Jürgen Moltmann. Rio de Janeiro, 2013. 118p. MSc. Dissertation - Departamento de Teologia, Pontifícia Universidade Católica do Rio de Janeiro.

This research focuses on the study of the subject of the Kerygma in the fragmented world. We seek to develop the theme from the German theologian Jürgen Moltmann's view. This research aims at the interaction between the reading of the Kerygma in Moltmann and pastoral proposals demands of the postmodern human being. The work develops into three chapters that seek to structure this essay: in the first, describes the decline of modernity and the consequent birth of Postmodernity, as well as the human being's existential postmodern configuration; in the second, develops the theological reading of the Kerygma Bible in Jürgen Moltmann; in the third, resumed the main points of reflections of previous chapters in order to provide pastoral proposals Kerygmatics the demands of the human being today. The Kerygmatic reading of that theologian proposes a pastoral attendance broadcasted through an existential and relational language, a Christology of the way, materializing orthodoxy in life coherent proclamation concrete to the existential situation of human beings of our time.

\section{Keywords}

Postmodernism; Kerygma; Human being; Christology; Ecclesiology. 


\section{Sumário}

1. Introdução

2. Configurando o ser humano pós-moderno 11

2.1 O paradigma racionalista moderno e seu declínio 11

$\begin{array}{ll}2.2 \text { O universo pós-moderno } & 14\end{array}$

2.3 A pós-modernidade e sua configuração existencial 18

$\begin{array}{ll}\text { 2.3.1 A subjetividade afetiva } & 19\end{array}$

2.3.2 Secularização e complexidade relacional entre sujeito e objeto $\quad 22$

2.3.3 A distensão individualista $\quad 29$

2.3.4 A angústia hedonista 34

2.3.5 A miséria consumista 38

3. O Kerygma do caminho em Jürgen Moltmann 45

3.1 O caminho da graça de Deus $\quad 45$

3.2 O caminho da inclusão $\quad 51$

3.3 O caminho da libertação de sistemas opressores 55

3.4 O caminho da livre doação amorosa 60

3.5 O caminho da vulnerabilidade $\quad 65$

$\begin{array}{ll}3.6 \text { O caminho da relacionalidade } & 68\end{array}$

$\begin{array}{ll}3.7 \text { O caminho da solidariedade } & 71\end{array}$

$\begin{array}{ll}3.8 \text { O caminho da regeneração } & 73\end{array}$

4. A pastoral kerygmatica moltmanniana frente às demandas do $\begin{array}{ll}\text { ser humano pós-moderno } & 77\end{array}$

4.1 O Kerygma para a sociedade de consumo 77

4.2 O Kerygma para a sociedade da subjetividade afetiva 82

4.3 O Kerygma para a sociedade secularista $\quad 88$

4.4 O Kerygma para a sociedade individualista 92

4.5 O Kerygma para a sociedade hedonista 99

$\begin{array}{ll}\text { 5. Conclusão } & 106\end{array}$

$\begin{array}{ll}\text { 6. Referências bibliográficas } & 114\end{array}$ 


\section{1 \\ Introdução}

Coexistir junto às demandas pós-modernas é realidade que traduz um desafio à proclamação do Kerygma. O ser humano atual vive uma época caracterizada pela desconstrução e descontinuidade marcada por uma constante incerteza oriunda de uma dominante ambivalência, onde a subjetividade racionalista cedeu lugar a uma subjetividade afetiva "enredada unilateralmente no domínio do afetivo", ${ }^{1}$ o que o possibilita ao mesmo viver de forma autônoma e opcional sua experiência de fé num universo religioso difuso cada vez maior. ${ }^{2} \mathrm{Na}$ liberdade de sua autonomia o indivíduo rompeu com as amarras da ordem coletiva que visaram oferecer normatividade disciplinar e moral autoritária, mas que por sua vez, poderiam contrariar a afirmação plena de seu princípio de individualidade. ${ }^{3}$ Mergulhado numa cultura cotidiana dominada pela mitologia da felicidade privada e pelos ideais hedonistas, ${ }^{4}$ o ser humano vive na sociedade hodierna, a efemeridade do consumo que nunca satisfaz, regido pela lei da transitoriedade, quando, na sociedade atual, nada se destina a permanência. ${ }^{5}$

\footnotetext{
${ }^{1}$ RUBIO, Alfonso Garcia. Unidade na pluralidade: o ser humano à luz da fé e da reflexão cristãs. São Paulo: Paulus, 2001, pp. 45-46. A professora Maria Clara Bingemer explica que apesar de se constatarem ainda hoje, hesitações, medos, fugas e tentativas impossíveis de retorno ao antigo cristianismo pré-moderno, objetivando resgatar a hegemonia perdida pela religião institucionalizada na história, a própria modernidade se encontra em uma crise profunda, por conta das utopias que ajudaram a concretizar seu modelo, e ainda, a emergência de uma nova subjetividade que questiona a concepção do ser humano configurada principalmente pela racionalidade, trazendo novamente a tona valores como afetividade, gratuidade e contemplação, que haviam sido deixados no passado. Cf. BINGEMER, Maria Clara. Cristianismo secularizado: novos desafios. In ANDRADE, Paulo Fernando Carneiro de; BINGEMER, Maria Clara. Secularização e experiência de Deus. Rio de Janeiro: PUC-Rio, 2012, p. 111.

${ }^{2}$ Id. Faces e interfaces da sacralidade num mundo secularizado. Revista de Teologia e Ciências da Religião, Ano VII, n. 7, dezembro/2008, p.27.

${ }^{3}$ LIPOVETSKY, Gilles. A cultura-mundo: resposta a uma sociedade desorientada. São Paulo: Companhia das letras, 2011, p. 47.

${ }^{4}$ GONZÁLEZ-CARJAVAL, Luís. Educar em un mundo postmoderno. Revista Educadores $n^{0}$ 34/1992, pp. 7-27. Disponível em: de maio de 2012. Segundo o teólogo José Comblin a vida na cultura urbana fragiliza as pessoas trazendo-lhes inseguranças e angustias. Por isso, muitas procuram tranquilidade e paz para encontrarem equilíbrio interior, partem em busca de sentido , valor e identidade, algo que lhes faça sentirem-se estabilizadas. O ser humano atual padece de continua insatisfação, procurando abafa-la através de infinitos recursos de diversão oferecidos pelo mercado. Segundo ele, a atual cultura dominante de satisfação, não tem haver com um tipo de satisfação adquirida, mas sim com uma satisfação em estado de procura, de questionamento e de angústia, pois a humanidade se encontra a procura da felicidade e se esgota em sua ansiosa tentativa. Cf. COMBLIN, José. Cristãos rumo ao século XXI: nova caminhada de libertação. São Paulo: Paulus, 1996, p. 333.

${ }^{5}$ BAUMAN, Zygmunt. Vidas desperdiçadas. Rio de Janeiro: Zahar, 2005, p. 120.
} 
Partindo dessa realidade existencial a presente dissertação tem por objetivo a reflexão de um comparecimento pastoral kerygmático, que possa interagir em diálogo direto com as demandas do ser humano pós-moderno. Mais especificamente, ela pretende, através das verdades ensinadas e vivenciadas pelo Deus encarnado, morto e ressuscitado, atualizar a proclamação do Kerygma à realidade vigente de nossa sociedade.

Adotamos a metodologia esquematizada em “ver-julgar-agir”, que será desenvolvida subseqüentemente em três capítulos.

Considerando que a mensagem de Jesus Cristo e os valores do seu Reino sempre estiveram profundamente comprometidos com a realidade humana, iniciaremos o primeiro capítulo desse trabalho compondo uma panorâmica descrição sobre o universo referente à transição ocorrida entre os períodos moderno e pós-moderno, seguida da análise de algumas das principais demandas humanas interiores e relacionais envolvidas na atual conjuntura social.

Nosso segundo capítulo propõe ler o Kerygma bíblico a partir das lentes do teólogo da vida Jürgen Moltmann, que apregoa a mensagem viva do Deus encarnado, sensível e solidário, que caminha com o ser humano em seu dia a dia, nas crises e dramas de sua vida.

Finalmente, no terceiro e último capítulo é nosso intuito, a partir da reflexão na teológica de Jürgen Moltmann sobre o Cristo do caminho, propor um coerente comparecimento proclamativo de cunho prático pastoral às referidas demandas humanas “pós-modernas” analisadas.

Partindo da configuração existencial do ser humano pós-moderno através de diagnóstico sócio-teológico, em suas crises, valores, percepções e perspectivas sobre si, seu mundo e o sagrado hoje, cumprir-nos propor uma responsiva hipótese a principal questão levantada por essa pesquisa, a saber: como proclamar as boas novas de nosso Senhor Jesus Cristo a essa geração?

O presente trabalho propõe com base na leitura kerygmática moltmanniana um responso teológico pastoral veiculado a uma linguagem existencial e relacional, materializando ortodoxia em concreto comparecimento proclamativo ortopráxico coerentemente presente a situação existencial do ser humano de nossa época. A materialização da mensagem proclamada ocorrerá na medida em que seu anunciante expressar a fé através de sua experiência de vida cotidiana concreta, que é onde o ser humano verdadeiramente experimenta sua valorização como 
cidadão do Reino de Deus. Para tal, compreendemos que o anuncio Real em sua essência deverá fomentar uma participação cívica, responsável e criativa do indivíduo, rejeitando toda e qualquer alienação a atual realidade contextual em que este se encontra inserido. Assim, a proclamação do Reino realmente corresponderá às verdades de vida eterna e dignidade humana, pautadas em relações verdadeiramente justas. Tal experiência de fé em Deus e em seu enviado Jesus Cristo, proporcionada pelo seu Espírito geram uma verdadeira e imprescindível qualidade de vida a ser alcançada em nossa existência. Portanto, propomos nessa pesquisa a reflexão de um anúncio kerygmático que tem por objetivo humanizar e otimizar a vida do ser humano em nossa época, centrado em Jesus Cristo e na realidade cívico existencial do seu Reino inaugurado.

Esperamos, ainda que de forma modesta, poder contribuir com a tarefa eclesiástica pastoral em sua processual caminhada de discernimento e evangelização do ser humano hodierno. 


\section{2 \\ Configurando o ser humano pós-moderno}

A partir do declínio da modernidade e o consequente nascimento da pósmodernidade, ocasionando inúmeras transformações a diversos setores da vida, temas como subjetividade afetiva, secularismo, individualismo, consumismo e hedonismo passaram a constituir importante objeto de estudos a quem deseja anunciar as boas novas de Jesus Cristo a essa geração. Sua compreensão constitui atualmente uma chave para a decodificação social humana.

Portanto, o primeiro capítulo dessa dissertação empenha-se por fornecer uma configuração existencial atualizada do ser humano na pós-modernidade, refletindo sobre o desenvolvimento de demandas sociais que têm influenciado substancialmente o modo de vida e comportamento humano.

\section{1. \\ O paradigma racionalista moderno e seu declínio}

O ser humano dos três últimos séculos sustentou e norteou sua existência sob o princípio de individualidade manifestado tridimensionalmente em sentimentos, razão e liberdade expressos na vontade de expansão do sujeito autônomo. ${ }^{6}$ Tal autonomia ganhou sistematização nas mais variadas esferas culturais e sociais, onde cada setor da vida humana procurava agora desenvolver sua lógica e regras específicas, sua inteligibilidade e normatividade. ${ }^{7}$

Assim, buscou-se construir a vida pessoal e social sobre os fundamentos da afirmação do poder da razão e da técnica; do laicismo das instituições e dos valores; do protagonismo do sujeito no pensamento e na ação política; da rejeição à tradição, à autoridade e ao dogma e da crença em valores como o progresso e o trabalho. ${ }^{8}$ Uma época de linha temporal linear caracterizada pela constante superação e rápida substituição de novidades já envelhecidas. ${ }^{9}$ Trata-se de uma era galopante, mas também ambiciosamente frustrada, assim caracterizada pelo sociólogo polonês Zygmunt Bauman:

\footnotetext{
${ }^{6}$ Cf, CASTIÑEIRA, Ángel. A experiência de Deus na pós-modernidade. Petrópolis: Vozes, 1997, p. 110.

${ }^{7}$ Cf. LIBANIO, João B. Teologia da revelação a partir da modernidade. São Paulo: Loyola, 2005, pp. 137-138.

${ }^{8}$ CASTIÑEIRA, Ángel. Op. cit., pp. 110-111.

${ }^{9}$ Ibid., p.119.
} 
Da crença de que há um fim do caminho em que andamos, um télos alcançável da mudança histórica, um Estado de perfeição a ser atingido amanhã, no próximo ano ou no próximo milênio, algum tipo de sociedade boa [...] da ordem perfeita em que tudo é colocado no lugar certo...do completo domínio sobre o futuro. ${ }^{10}$

Assim, a modernidade se apresentou como uma marcha obsessiva onde sempre se almejava mais. Entretanto, nunca se consegue o bastante. Um momento marcado por muitas aventuras amargas e ambições frustradas que acabaram gerando mais ansiedade à sua expectativa de progresso. Na verdade, qualquer ponto de chegada não passava de uma ambição temporária que não satisfazia, pois toda perturbadora conquista transformava-se em resíduo de combustíveis queimados e fuligens de chamas extintas, sinais efêmeros daquela trajetória de progresso. $^{11}$

Numa eufórica e universal ambição cognitiva, muitos pensadores do século XVII tentaram escrever uma enciclopédia que contivesse o conhecimento sobre todas as coisas, típico exemplo da pretensão moderna. ${ }^{12}$

A razão humana buscava, sem restrições, perscrutar todos os setores e espaços da vida. Do macroscópico ao microscópico; dos espaços siderais ao inconsciente do humano, do mais remoto passado ao misterioso futuro. Paradoxalmente ela aspirava a uma totalidade que não tem limite, nem de tempo, nem de espaço. ${ }^{13}$

Como Jung Mo Sung explica, a humanidade nutria um forte otimismo por seu inerente potencial para um previsível progresso rumo a uma sociedade perfeita:

O futuro desejado será alcançado pelo desenvolvimento das potencialidades já existentes na instituição vigente. O caminho para o futuro já está traçado e é conhecido. Não há mais inquietações. Não há mais dúvidas, nem incertezas. Aqui está uma das fontes, senão a principal, da crise da modernidade. Toda modernidade interpretou a utopia como uma sociedade perfeita a ser alcançada por um projeto político. ${ }^{14}$

Entretanto, mesmo sabendo-se que progressos científico-tecnológicos alcançados conceberam muitas vezes um efeito totalmente oposto ocasionando mudanças climáticas e subseqüentes riscos provenientes de abusiva intervenção

\footnotetext{
${ }^{10}$ BAUMAN, Zygmunt. Modernidade Líquida. Rio de Janeiro: Zahar, 2005, p. 37.

${ }^{11}$ Cf. Id. Modernidade e ambivalência. Rio de Janeiro: Zahar, 1999, p. 18.

${ }^{12}$ Cf. SUNG, Jung Mo. Deus numa economia sem coração. Pobreza e neoliberalismo: um desafio à evangelização. São Paulo: Paulus, 1992, p. 77.

${ }^{13}$ Cf. LIBANIO, João B. Teologia da revelação a partir da modernidade. p. 138.

${ }^{14}$ Ibid., pp. 77-78
} 
humana no ambiente, ${ }^{15}$ os maiores efeitos colaterais advindos do referido progresso moderno, foram sem dúvida as guerras e barbáries, provando que o pensamento moderno não havia amadurecido o ser humano tanto assim, e nem conduzido a civilização ocidental a um futuro melhor. ${ }^{16}$

Um afloramento de tendências homicidas encobertas, embora inatas por parte de alguns líderes políticos; a predominância de peculiar e mórbida filosofia nacionalista, ou ainda, uma inacabada progressão civilizacional vigente não perfizeram por si só a totalidade estrutural ocasionadora de tamanho massacre. A conta não fecha e não se exorciza totalmente a causa, pois como assevera Zygmunt Bauman, a Alemanha da década de trinta era vista por esclarecidos e respeitados órgãos de opinião de sua época, como os jornais “Times” e "Figaro" entre outros, como o paradigma de Estado civilizado, da prosperidade, da paz social, dos sindicatos operários obedientes e cooperativos, da lei e da ordem. Era o mito etiológico do triunfo da civilização moderna sobre as paixões, assim como a crença de que esse triunfo teria sido um passo inequívoco do progresso no desenvolvimento histórico da moralidade pública.

Assim, o estado moderno hasteou-se como uma força missionária mormente proselitista, numa cruzada empenhada em submeter as populações dominadas a um exame completo pretendendo transformá-las numa sociedade ordeira, afinada com os preceitos da razão. A suposta e inquestionável autoridade da razão ditou critérios que dividiam a população em plantas a serem estimuladas e cuidadosamente cultivadas e ervas daninhas a serem removidas ou arrancadas. ${ }^{17}$ O que, portanto, era receita certa de guerra e genocídio, mas também de reflexão e destronamento do paradigma moderno.

Nascia assim, por parto normal precedido de muitas contrações e dores a “pós-modernidade”. O tão aspirado auge da maturidade moderna transformou-se numa verdadeira concepção normal, sem pré-natal e sem anestesia. Um parto de risco, mas inadiável.

\footnotetext{
${ }^{15}$ GIDDENS, Anthony. Mundo em descontrole: o que a globalização está fazendo de nós. Rio de Janeiro: Record, 2002, p. 14.

${ }^{16}$ RUBIO, Alfonso Garcia. A caminho da maturidade na experiência de Deus. São Paulo: Paulinas, 2008, p. 17.

${ }^{17}$ BAUMAN, Zygmunt. Modernidade e ambivalência. pp. 28-29.
} 


\section{2. \\ O universo pós-moderno}

Estruturalmente é interessante notar que dentre as mudanças pelas quais passou a sociedade durante a segunda metade do século XX, mais especificamente após a década de sessenta, o acontecimento mais significativo foi a chegada da era da informação.

Concentrando-se na produção de bens, a modernidade produziu a fábrica, que era o símbolo de uma sociedade industrial, cujo objetivo central era a produção de bens. A era pós-moderna focou-se principalmente na produção de informações, cujo símbolo era o computador.

Uma classe totalmente nova de pessoas tomava lugar de destaque nesta sociedade. Uma comunidade de informações ascendia, enquanto a participação e a descentralização abalaram rígidas autonomias hierárquicas.

Entretanto, muito mais do que modificar estruturas, a era da informação também aproximou o mundo de um modo jamais concebido anteriormente. Assim, de uma época em que a velocidade das informações atinha-se ao deslocamento dos seres humanos, aos quais anteriormente fora possibilitado uma melhor conexão graças aos significativos progressos modernos proporcionados pelos avanços na área dos transportes, passou-se então a obter informação de todos os lugares da terra quase que instantaneamente. ${ }^{18} \mathrm{O}$ que também, como assevera Gilles Lipovetsky veio a acrescentar um concomitante estreitamento de ameaças:

Graças ao desenvolvimento do universo midiático e do espaço cibernético, já existe a possibilidade de estar informado sobre tudo, em qualquer lugar, uma vez que os recantos mais isolados estão ligados ao global. Cada vez mais, os homens perfazem a experiência de um só mundo, no qual as interdependências, as interconexões e interações se ampliam [...]. Todavia, nada impede que concomitantemente a esse “cosmopolitanismo de aeroportos internacionais”, se manifeste a experiência de um mundo unificado, mediante ameaças ecológicas, difusão "por transporte aéreo" das epidemias virais, atos terroristas, grandes acontecimentos mundiais: fenômenos que desconhecem fronteiras e são percebidos desse modo. ${ }^{19}$

Portanto, neste caso, vale observar que a viabilização ocasionada pelo referido progresso aumentou riscos encurtando vias de acesso.

\footnotetext{
${ }^{18}$ Cf. GRENZ. Stanley J. Pós-Modernismo: um guia para entender a filosofia do nosso tempo. São Paulo: Vida, 2008, pp. 33-34.

${ }^{19}$ HERVÉ, Juvin; LIPOVETSKY, Gilles. A Globalização ocidental: controvérsia sobre a cultura planetária. São Paulo: Manole. 2012, p. 5.
} 
Outro dado interessante, é que ao contrário do projeto moderno de uma sociedade humana perfeita onde reinariam a paz o amor e a justiça, a pósmodernidade oferece uma incomensurável diversidade, onde a palavra de ordem é pluralidade. Artistas pós-modernos justapõem estilos que realçam aparentes paradoxos justificados por sua origem advinda de fontes imensamente diferentes, fazendo florescer uma criativa e sutil rejeição ao predomínio da racionalidade. Obras que consistem na constante variação de estilos e dupla codificação de significado, denotando, por conseguinte, um ecletismo oriundo de muitas eras históricas. Destitui-se a poderosa e criativa figura do autor tão idealizada no período moderno, ${ }^{20}$ onde a imaginação e a atividade humana eram receita certa de sucesso futuro, ${ }^{21}$ substituindo-a por uma cultura de estilos múltiplos, onde uma pluralidade de mensagens dissonantes ressoa de fora do contexto.

$\mathrm{Na}$ modernidade a arquitetura, em suas tendências e inclinações, era norteada pela fé na racionalidade humana e pela esperança da construção da utopia humana, elaborando edificações segundo o princípio da unidade que expressavam um significado único e essencial. ${ }^{22}$ Em sua luta para impor sua legitimidade decretou o fim da arte tradicional, seu funcionalismo depositou sua esperança na utilização de novos materiais tecnológicos. Seu devir recalcava o passado. $^{23}$

O edifício moderno deveria ser uma unidade orgânica, apresentando formas simples e essenciais tipificadas pelo padrão praticamente universal das estruturas quadradas de vidro e aço. Alcançava-se a simplicidade das formas através da predominância de uma temática na construção por meio de um dispositivo chamado de "repetição".

Promovendo um programa de industrialização e rebaixando a variedade característica da expressão local, a arquitetura moderna tornou-se um movimento universalizante. À medida que destruía o tecido urbano existente ela praticamente dizimava tudo que estava no caminho de seu principal instrumento moderno de progresso: a escavadeira. ${ }^{24}$

\footnotetext{
${ }^{20}$ Cf. GRENZ. Stanley J. Pós-Modernismo. pp.37-39.

${ }^{21}$ Cf. CASTIÑEIRA, Ángel. A experiência de Deus na pós-modernidade. p. 114.

${ }^{22}$ Cf. GRENZ. Stanley J. Op.cit., pp. 39-40.

${ }^{23}$ Cf. ORTIZ, Renato. Reflexões sobre a pós-modernidade: o exemplo da arquitetura. Disponível em: <http://www.anpocs.org.br/portal/publicacoes/rbcs_00_20/rbcs20_10.html> Acesso em: 22 jan. 2013.

${ }^{24}$ Ibid., pp.39-40.
} 
Assim, o modernismo revelava o seu esforço "totalitário", objetivando impor uma só verdade. Proclamava um programa inflexível de vivência, prometendo a felicidade humana pelo progresso e o desenvolvimento. Entretanto, a reação pós-moderna rebelou-se através de um ecletismo contra esse estado de coisas, uma resposta à "tirania do novo", uma valorização do pluralismo da vida diante da coerção das ideologias, uma democrática forma de criatividade. ${ }^{25}$

Por isso, a proposta arquitetônica pós-moderna diferia da anterior porque regozijava-se na multivalência ao invés da univalência. Suas construções resgatavam reminiscências de épocas anteriores através de estilos e técnicas históricos e abriam lugar ao supérfluo valorizando a ornamentação, por meio da qual tentavam restaurar o componente fictício da arquitetura. Viam um simbolismo inerente em toda a arquitetura.

$\mathrm{Na}$ verdade, o intuito de tal arquitetura traduz-se na tentativa de abandonar a linguagem de poder da qual os arquitetos modernos pareciam não ter consciência. Desejam se afastar daquilo que consideram uma uniformidade humanizadora de uma arquitetura que expressava uma linguagem de produção em massa padronizada. Por conseguinte, procuram explorar novas linguagens híbridas que incorporem conceitos de diversidade e pluralismo. ${ }^{26}$

Assim como a arquitetura moderna, a arte tentava expurgar de si tudo aquilo que não se enquadrava em seus padrões de exigência. Sendo assim, sua principal característica era a integridade estilística. ${ }^{27} \mathrm{Em}$ contrapartida, o período pósmoderno é marcado pela fecundidade de manifestações artísticas expressas mediante uma imensa variedade de estilos, formas e práticas que culminaram numa riqueza de diversidades estonteantes. ${ }^{28}$ Muitos artistas pós-modernos combinam a diversidade com a crítica tipicamente pós-moderna da justaposição. A colagem, como uma de suas formas prediletas de composição, sugere claramente a subjetividade do observador quanto à produção de sentido, enquanto que a heterogeneidade da referida colagem assegura que tal sentido por ela suscitado não seja unívoco e nem estável. Esta justaposição de imagens constantemente sugere ao observador um novo significado.

\footnotetext{
${ }^{25}$ Ibid.

${ }^{26}$ Ibid., pp. 41-43.

${ }^{27}$ Ibid., pp. 43-44.

${ }^{28}$ SANTAELLA, Lúcia. Culturas e artes do pós-humano: da cultura das mídias à cibercultura. São Paulo: Paulus, 2003, p. 320.
} 
Através de métodos como a confiscação, a citação, os enxertos, acumulação e repetições óbvias de imagens já existentes, os artistas pós-modernos atacam a ficção do sujeito criador, desafiando assim o enfoque modernista sobre a integridade estilista do trabalho individual e minando uma espécie de culto modernista à individualidade do artista. ${ }^{29}$

A performance teatral pós-moderna estabelece um conflito entre seus diferentes elementos, tais como o som, a luz, a linguagem, o cenário e o movimento. Em oposição à antiga estética da presença, tal performance de caráter específico, reflete uma estética da ausência que rejeita a ideia da evidência de um sentido de verdade subjacente e permanente. ${ }^{30}$

Quanto às obras de ficção, se anteriormente o propósito do autor modernista era a obtenção de certo controle sobre a realidade complexa, não obstante singular, trabalhos pós-modernos nesta área suscitam perguntas acerca da coexistência e da interpretação de realidades tão diferentes.

Negando implicitamente o ideal moderno de uma verdade atemporal e universal e similarmente a outras expressões culturais pós-modernas, a literatura enfoca a contingência e o caráter temporal. A ênfase da ficção pós-moderna volta também sua atenção sobre o temporal ao deslocar o leitor de sua tentativa de observar o mundo de um ponto estratégico fora do tempo. Tais autores comunicam em suas obras, por muitas vezes propostas de descentralização de pensamentos obtusos e desconstrução de estruturas, colocando em dúvida os dogmas estritamente racionais como meio de negação à possibilidade de que qualquer discurso seja capaz de apresentar, em última análise, um relato do real. ${ }^{31}$

O pós-modernismo penetrou na indústria cinematográfica viabilizado por seus peculiares desenvolvimentos tecnológicos. Se por um lado, o filme, por sua ordenação de imagens, comparado ao vídeo clip possa parecer expressão da modernidade, ${ }^{32}$ porém, na realidade, sabe-se que o mesmo é fruto de uma produção tecnológica montada por uma gama de especialistas com base numa série de materiais e em diversas técnicas que raramente aparecem de modo explícito no filme. Sua unidade, por este ângulo, é ilusória. Suas cenas em

\footnotetext{
${ }^{29}$ Cf. Ibid., pp. $44-45$.

${ }^{30}$ Cf. Ibid., p. 48.

${ }^{31}$ Cf. Ibid., pp. 50-51.

32 Cf. PURIM, Paulo. R. Pós-modernidade e proclamação. Disponível em Http://kerigmaonline.blogspot.com/2006\%2002\%2001arhive.html. Acesso em: 25 de julho de
} 2011. 
representação contínua são oriundas de uma produção de fragmentos no tempo e no espaço. A continuidade de cenas apresentadas é produto de uma compilação de eventos filmados inúmeras vezes em variadas locações e dificilmente refletem a ordem em que foram filmadas. Os cineastas têm significativa liberdade de fragmentar e manipular a história de diversas maneiras, já que a unidade de um filme não depende da narrativa em si mesma, mas das técnicas do processo de filmagem. Assim, cineastas põem abaixo o espaço e o tempo, transformando-o num aqui e agora sem fim, pois um número crescente de filmes previamente filmados lhes permite variados tipos de extrações que acrescentam novas sequencias. $^{33}$

Portanto, assumindo diversas formas, o universo pós-moderno perpassa e se expande em atitudes e expressões culturais variadas, tais como a arte, a arquitetura, a literatura, o teatro e o cinema entre tantas outras, a fim de celebrar a diversidade, proclamar a pluralidade, questionando assim qualquer pretensão de análise privilegiada que venha a emitir uma verdade absoluta para humanidade.

\section{3.}

\section{A pós-modernidade e sua configuração existencial}

A "pós-modernidade", ${ }^{34}$ trouxe consigo um estonteante caleidoscópio humano-cultural. Uma época caracterizada pela desilusão das pretensões da razão, onde o sentido da história é reavaliado e o totalitarismo humanista questionado; onde vozes, formas e modelos paradigmáticos coexistem cada qual por sua especificidade aplicativa; e também onde enigma, desconstrução e descontinuidade são ordinários componentes existenciais. ${ }^{35}$

Luís Carlos Fridman diagnostica esta fragmentária era subjetiva como uma época em que todas as convicções do ser, como seu certificado de existência, se diluem; a unidade existencial se desfaz no descarte sucessivo de intensidades momentâneas fazendo acumular o estado de ansiedade. Assim, a identidade, sob

\footnotetext{
${ }^{33}$ GRENZ, Stanley J. Pós-Modernismo., pp. 53-54.

${ }^{34}$ Quando nos referimos ao termo "pós-modernidade" não o fazemos como produto final de uma aferição conceitual, mas como nomenclatura abarcadora de variados termos e conceitos componentes ao atual universo hodierno em análise. Embora os eruditos discordem quanto a que teria cunhado o referido termo pela primeira vez, existe um consenso de que tenha aparecido por volta da década de trinta. Charles Jencks um respeitado proponente do pós-modernismo, afirma que a gênese do conceito acha-se na obra do escritor espanhol Frederico de Onis. Em sua antologia de La poesia española e hispano-americana (193), de Onis parece ter introduzido o termo para se referir a uma reação dentro do modernismo. Cf. Ibid., p. 31.

${ }^{35}$ CASTIÑEIRA, Ángel. A experiência de Deus na pós-modernidade. pp. 119-120.
} 
marca de transitoriedade nunca se completa. Dá-se, portanto, o fruir constante de um complexo e subjetivo momento existencial como se expõe a seguir. ${ }^{36}$

\subsection{1.}

\section{A subjetividade afetiva}

Alfonso Garcia Rubio assim descreve a constelação “pós-moderna”.

Em contraste com o triunfalismo antropocêntrico da modernidade, desenvolve-se uma visão pessimista e diminuída do ser humano. Os poderosos sistemas filosóficos do passado que tem alicerçado fortes ideologias de dominação cedem o lugar a um tipo de pensamento “débil”, inseguro, aproximativo, conjectural com outros tipos de pensamentos também contingentes e aproximativos... A crença moderna no progresso indefinido é questionada radicalmente e, assim, as filosofias modernas da história despertam pouco ou nenhum interesse... À subjetividade racionalista sucede uma subjetividade enredada unilateralmente no domínio do afetivo... A descrença em relação à razão humana unida ao pessimismo face às possibilidades do ser humano na sociedade e no cosmos levou a uma acentuada desconfiança diante dos compromissos sociais e políticos. E acresce que se encontra também muito generalizada a desconfiança em relação às instituições. ${ }^{37}$

Trata-se de uma época flutuante, marcada por uma constante incerteza oriunda de uma dominante ambivalência onde até mesmo os progressos e descobertas científicas atuais acentuam-se como líquidos e a procura de satisfações imediatas como o utilitarismo, o pragmatismo e o consumismo é o produto resultante. ${ }^{38}$

Este desconforto é descrito pelo sociólogo polonês Zygmunt Bauman da seguinte forma:

Quando dizemos que coisas ou situações são ambivalentes, o que desejamos dizer é que não podemos estar certos do que vai acontecer, nem saber como nos comportar, tampouco prever qual será o resultado de nossas ações... No fenômeno da ambivalência, as dúvidas da razão e a indecisão da vontade, as respectivas vontades dos dois ingredientes que integram a mente humana, encontram-se e se misturam. O mundo - o domínio da razão - aparece pouco claro (isto é, emite sinais obscuros, até mesmo contraditórios) quando a vontade não está segura do que escolher; a falta de clareza do mundo, relatada pela razão, e a incerteza, sofrida pela vontade, crescem juntas e retrocedem juntas. ${ }^{39}$

\footnotetext{
36 Cf. FRIDMAN, Luís Carlos. Vertigens pós-modernas: Configurações institucionais contemporâneas. Rio de Janeiro: Relume Dumará/Sinergia/Ediouro, 2009, p. 65.

${ }^{37}$ RUBIO, Alfonso Garcia. Unidade na pluralidade. pp. 45-46.

${ }^{38}$ Cf. Ibid., p. 46.

${ }^{39}$ BAUMAN, Zygmunt. A Sociedade individualizada: vidas contadas e histórias vividas. Rio de Janeiro: Zahar, 2008, pp. 78-79.
} 
Através destas respeitadas subsequentes elucidações citadas, se percebe que o protagonismo da razão cartesiana tornou-se insustentável ou inconcebível a esta era.

Realmente, quando os seres humanos pós-modernos ouvem o adjetivo “absoluto” depois da palavra "verdade”, eles pensam em tantos conceitos errados e atrocidades cometidas em nome de uma verdade absoluta, tais como o racismo norte-americano, que via os povos indígenas e os negros como inferiores; os nazistas, que consideravam uma verdade absoluta a necessidade do extermínio dos judeus; muitos industriais, que enxergavam no lucro sem escrúpulos uma verdade absoluta, mesmo que tal ganho comprometa gravemente a conservação do meio ambiente e vários políticos da atualidade, que consideram a guerra uma verdade absoluta, inadiável e inegociável, para se alcançar a paz. ${ }^{40}$

O ser humano hodierno criva certas proposições éticas, históricas e sociais, pela percepção de sua validade experiencial em sua formulação.

Assim, regras e normas morais encontram sua importância em sua descoberta existencial, a partir do protagonismo humano. Nesse particular a heteronomia moral cede seu espaço para a autonomia moral. ${ }^{41}$

O espírito pós-moderno questiona o conceito de uma verdade universal descoberta e provada graças a esforços racionais. Neste sentido, o intelecto humano não se faz mais o protagonista do crivo daquilo que se deve crer e elevam-se os olhos para além da razão, abrindo-se às emoções e às intuições, que atualmente gozam de um status privilegiado.

$\mathrm{Na}$ busca de um modelo cooperativo e de uma maior valorização das dimensões não racionais da verdade emprega-se uma dimensão holística à consciência. Assim, os seres humanos pós-modernos desejam ser pessoas mais completas. Este holismo envolve as dimensões afetiva, intuitiva e cognitiva da vida pessoal.

Atualmente desempenham importante papel a comunidade e a existência social. Além das crenças específicas, também a compreensão da própria verdade encontra-se enraizada na comunidade da qual se participa. A busca da verdade sai da esfera universal, supra-cultural e eterna para a de valor específico. A verdade

\footnotetext{
${ }^{40}$ MCLAREN, Brian D. A igreja do outro lado. São Paulo: Palavra, 2008, p. 235.

${ }^{41}$ BARTH. Wilmar L. O homem pós-moderno, religião e ética. Revista Teocomunicação. Volume 37, n 155, março de 2007, pp. 100.
} 
consiste de regras básicas que facilitam o bem-estar pessoal de uma comunidade ou de um todo. Daí a importância da comunidade como norte ou crivo de correta conduta na vida de um indivíduo. O que, portanto, torna comum a coexistência de uma pluralidade de verdades, já que são muitas as comunidades humanas. ${ }^{42}$

Portanto, como menciona Zygmunt Bauman, na pós-modernidade não há espaço para disputas sobre razão:

Porque a possibilidade de que diferentes opiniões podem ser não apenas simultaneamente julgadas verdadeiras, mas ser de fato simultaneamente verdadeiras, a teoria das verdades atualmente no centro da atenção dos filósofos parece ser privada de muito da sua função de disputa. ${ }^{43}$

De acordo com o senso pós-moderno, torna-se ainda mais importante do que a confirmação de uma certeza individual sobre determinada temática, um conhecimento também traduzido através de uma experiência coletiva, pois o grupo ao qual o indivíduo se associa exerce forte influência sobre aquilo que se conhece ou se pensa conhecer. Atualmente, deve-se à experiência a simplicidade do desfrute, e não sua transformação em outra teoria ou verdade universalizada. ${ }^{44}$

Devido ao valor que o ser humano pós-moderno dedica à união e ao correspondente medo de desintegração, ele não deseja uma verdade que não seja administrada sem doses iguais de manifestação de amor. ${ }^{45}$

Michel Maffesoli chama a atenção para a sensibilidade de uma "razão vital”, de um "raciovitalismo" ${ }^{46}$ que sabe unir os opostos: operar conhecimento, e, ao mesmo tempo, perceber as pulsões vitais, possibilitando ao ser humano uma melhor compreensão de sua existência. Na organicidade das emoções, sentimentos e culturas comuns imersos numa vida compartilhada, encontra-se o verdadeiro campo de reflexão intelectual, na tentativa de percepção existencial sobre as verdades da própria vida em movimento, ao vivo, enquanto esta acontece. Esta é a aspiração raciovitalista: a de nunca negligenciar parte alguma

\footnotetext{
${ }^{42}$ Cf. GRENZ. Stanley J. Pós-Modernismo. pp.28-29.

${ }^{43}$ BAUMAN, Zygmunt. O mal estar da pós-modernidade. Rio de Janeiro: Zahar, 1998, p. 147.

${ }^{44}$ Cf. MCLAREN, Brian D. A igreja do outro lado. p. 231.

${ }^{45}$ Cf. Ibid., p. 233.

${ }^{46}$ Este termo foi utilizado primeiramente por José Ortega y Gasset ao contexto secular do cristianismo. Cf. SAVIGNANO, Armando. Cristianismo secularizado. In PENZO, Giorgio \& GIBELLINI, Rosino. Deus na filosofia do século XX. São Paulo: Loyola, 1998, pp. 229-239.
} 
de toda a realidade ao seu redor, onde se está, numa compilação de tempo, sentimento e razão. ${ }^{47}$

Como ele próprio especifica conclusivamente:

Assim, ao contrário de uma Razão separada, intelectualista, desencarnada, a razão interna, particular é, antes de mais nada, específica. É feita de matéria, de concretude; é, ao mesmo tempo, transfigurada pelo dinamismo próprio da matéria, [...] É a busca de tal organicidade que faz a especificidade da situação pósmoderna. ${ }^{48}$

Portanto, mais do que um momento de ruptura epistemológica com a razão abstrata, ou de postura puramente intelectual e impositiva, trata-se de um momento onde ascende uma razão ancorada na sensível compreensão da existência humana mediada pela convivência e empatia. ${ }^{49}$

\subsection{2. \\ Secularização e complexidade relacional entre sujeito e objeto}

Desde a idade média, a luta pela emancipação do homem e da mulher como sujeitos, pessoas, transpareceu com frequência como um ato de insubordinação a cristandade vigente. Qualquer afirmação de liberdade pessoal era interpretada como ato de rebelião e manifestação de orgulho contra Deus que fazia conhecida sua vontade na vida de cada ser humano pelo lugar que este ocupava em sua sociedade. Assim, o clero exigiu aos cristãos medievais uma conformidade indiscutível com a ordem já estabelecida. ${ }^{50}$ Pois nenhuma sociedade podia subsistir, não fosse a coesão proporcionada pelo cimento de uma religião comum sacralizadora de normas e valores que norteavam o controle, a ordem e a estabilidade social. $^{51}$

A partir do século XIV apareceram claros sinais de formação de personalidades que não se contentaram tão somente em identificar o seu papel social: místicos que não desejavam separar-se da igreja, antes aceitavam todos os dogmas, ainda que, entretanto, a força viva de sua religião não se atinha mais aos

\footnotetext{
${ }^{47}$ Cf. MAFFESOLI, Michel. Elogio da razão sensível. Petrópolis: Vozes, 2005, p. 58.

${ }^{48}$ Ibid., p. 63.

${ }^{49}$ Cf. Ibid., pp.46-47.

${ }^{50}$ Cf. COMBLIN, José. Cristãos rumo ao século XXI. p. 305.

${ }^{51}$ Cf. GONZALÉZ-CARVAJAL, Luis. Cristianismo y Secularización: como vivir la fe em una sociedad secularizada. Santander: Sal Terrae, 2003, p. 40.
} 
gestos religiosos exteriores impostos pelas igrejas. Trata-se de uma época em que a mística empenhou-se em uma busca por Deus que não passava pela teologia escolástica, pelos sacramentos ou magistério. Aflorava-se então, uma nova classe de pessoas religiosas que contestavam o poder do clero na religião e construíam uma religião espiritual que descartava muitos dos elementos institucionais da igreja. $^{52}$

Enquanto isso, a poesia e a música trovadora exaltavam o amor novo, o amor herético que desafiava a moral estritamente familiar da cristandade. A escolástica já não era inspiração para os artistas, poetas e escritores, que recorriam a outras fontes semiclandestinas. Essa nova tendência sociocultural fugia totalmente ás rédeas daquela igreja.

Em uma época em que não se via fronteiras entre o real e a fantasia, o Renascimento trouxe a manifestação de um universo de pensamentos emancipados do domínio teológico escolástico. Pensar agora, já não consiste mais de um ato de subserviência intelectual ao magistério da igreja, mas em autônomo potencial de possibilidades. O predomínio de uma ideologia panteísta de Deus e do mundo convence o ser humano de que tal potencial se encontra em seu interior, onde ele mesmo pode estabelecer contato com a totalidade do Ser. Percebe-se o recurso advindo de todas as coisas e tudo influi no universo da vida humana. Afirma-se a existência de uma circulação de energia em tudo, e tudo deve e pode ser usado. Astros, plantas, pedras, animais e tudo mais compõem uma unidade divina reveladora de Deus, que está em todas as coisas. O mundo é revelador e a autoridade do magistério eclesiástico perde seu fundamento, pois o ser humano passa a conscientizar-se de que pode estabelecer um contato imediato com Deus sem lançar mão de viabilizadores atalhos fornecidos pelas igrejas, cristandade ou sistema escolástico autoritário.

O Renascimento conduz também a consciência individual a proclamar sua independência da cristandade a partir de uma nova leitura reflexiva e distintiva entre alma e corpo, de onde se origina uma nova percepção sobre a autonomia de vida da alma em relação ao corpo. Esta pode pensar por si mesma. Assim, a

\footnotetext{
${ }^{52}$ O teólogo José Comblin refere-se aos místicos, que continuaram a linha da espiritualidade praticada nos Países Baixos e da Renânia, todos marcados por Mestre Eckhart, que foi capaz de enunciar temas que eram bastante universais neste mundo de cidades livres ou Comunas. Apesar das condenações dos papas, o referido movimento místico, espalhado entre os Beguinas e os Bagardos, em sua grande maioria, permaneceu ortodoxo. Cf. COMBLIN, José. Cristãos rumo ao século XXI. p. 306.
} 
consciência, a alma, o espírito pessoal, não necessitam da mediação da matéria. Manifesta-se, ainda que de forma discreta, mas muito sugestiva, uma tentativa de desvio da institucionalidade da igreja e seus peculiares símbolos materiais como padres, sacramentos e demais acessórios da cristandade. ${ }^{53}$

Os reformadores, por sua vez e com sua peculiaridade teológica, também objetaram a cristandade vigente priorizando o sujeito individual em nome do próprio cristianismo e não a partir de elucubrações secundárias como já referido. Empunharam a Bíblia contra o magistério e a escolástica, submetendo a fé diretamente a Deus antes mesmo de qualquer instituição eclesiástica. ${ }^{54}$

Entretanto, o ápice da emancipação do sujeito se deu no período moderno, quando a filosofia empunhou a bandeira do "eu pensante" como uma realidade independente daquele sistema por séculos apregoado e dominado pela cristandade. $^{55}$

Um período em que, para alcançar a verdade, a revolução científica utilizouse de um método autônomo, despedindo assim a cognição humana de toda e qualquer tutela religiosa, renunciando aos meios sobrenaturais e avançando rumo à descoberta, efetivação e desenvolvimento de novas técnicas. ${ }^{56}$

A secularização moderna pôs fim a um tempo em que a igreja deteve a última palavra institucional nas mais diversas áreas de sua sociedade. ${ }^{57}$

Como descreve João Batista Libânio, a religião teve de se ater ao lugar especifico que lhe foi reservado nessa nova sociedade emergente:

A religião constitui-se uma esfera própria de saber. Torna-se objeto de pesquisa da razão. Adquire sua cidadania, entre outras realidades, desde que procure encontrar sua carteira de identidade e não queira invadir território alheio. As civilizações tradicionais reclamavam de textos fundadores, e a revelação cristã o foi para o ocidente cristão. Nelas o sagrado instituía e legitimava a sociedade. A modernidade, porém, não admite texto fundador, já que ela mesma quer ser seu fundamento $\left[\ldots . .{ }^{58}\right.$

Toda uma nova ordem política, econômica e cultural passou a existir e expandiu-se a partir do cidadão emancipado, que se tornou proprietário e

\footnotetext{
${ }^{53}$ Cf. Ibid., pp. 307-308.

${ }^{54}$ Cf. Ibid., p. 309.

${ }^{55}$ Cf. Ibid., p. 311.

${ }^{56}$ Cf. GONZALÉZ-CARVAJAL, Luis. Cristianismo y Secularización. p. 46.

${ }^{57}$ Cf. Ibid., pp. 48-49.

${ }^{58}$ LIBANIO, João B. Teologia da revelação a partir da modernidade. p. 138.
} 
produtor, fundamentando a validade do novo sistema sobre uma racionalidade própria e livre de regras sociais antes impostas pela cristandade. ${ }^{59}$

$\mathrm{Na}$ sociedade moderna descartou-se a necessidade de uma uniformidade religiosa para a vivência mútua. Pois um alistamento de objetivos práticos apoiados pela razão e aceitos pelos cidadãos vigentes, quaisquer que fossem as suas crenças, forneceriam um gerenciamento competente a referida demanda. ${ }^{60}$

Na esfera política, o estado, agora livre do aval sagrado da igreja, encontrava sua legitimação não mais em um governo em nome de Deus, mas sim em nome do povo, pelo tempo e nas condições que o povo queria, produzindo assim, uma rigorosa separação entre igreja e estado, onde o último gerenciava com exclusividade os assuntos públicos. ${ }^{61}$

Tal esforço descentralizador gerava neste momento, uma intenção de engajamento social salutar, como explica o teólogo espanhol Luis GonzálezCarvajal:

[...] en la medida en que la secularización entierra esa falsa imagen de Dios y hace al hombre responsable de los problemas intramundanos, nadie puede dudar que la secularización es beneficiosa tanto para la sociedad como para la Iglesia. ${ }^{62}$

De certa forma, a sociedade que responsabilizava Deus por todas as coisas, e até por causas secundárias de sua competência, passou a assumir um comparecimento civilmente responsável buscando, a princípio, equilibrar conceituações humanas distorcidas vigentes na época medieval anterior sobre o papel e a imagem de Deus e as incumbências do ser humano em sua sociedade.

A atividade econômica que durante séculos havia sido regida por princípios da ética cristã, tais como preço justo, proibição da usura e outros tipos de exploração, teve sua dependência ética pulverizada pela expansão do capitalismo moderno. Passou a caber à economia não mais o crivo ético entre o bem e o mal, mas o crivo técnico entre o eficaz e o ineficaz para o lucro financeiro. ${ }^{63}$

\footnotetext{
${ }^{59}$ Cf. COMBLIN, José. Cristãos rumo ao século XXI. pp. 311-312.

${ }^{60}$ Luís González-Carvajal menciona que o teólogo Hugo Grocio foi o precursor desta nova atitude, compondo, no começo do século XVII, uma grande obra sobre direito internacional intitulada De iure belli ac pacis, inédita em seu gênero, na qual, se propunha a justificar e validar sua premissa de que as leis que regulavam a convivência na sociedade, podiam e deviam fundamentar-se na razão humana. Sua obra Adnotationes in libros evangeliorum (1641-1650) foi uma das pioneiras da exegese neotestamentária de linha arminiana. Cf. GONZÁLEZ-CARVAJAL, Luis. Cristianismo y Secularización. pp. 40-42.

${ }^{61}$ Cf. Ibid., pp. 43-44.

${ }^{62}$ Id. Ideeas y creencias del hombre actual. Santander: Sal Terrae. 1991, p. 50.

${ }^{63}$ Cf. Ibid., pp. 44-45.
} 
Não obstante haver fundado a separação entre sujeito e objeto, consciência individual e ordem no mundo, os modernos necessitavam restaurar uma base racional que substituísse a cristandade unindo sujeito e objeto, para refazer um mundo de ordem e progresso. Sabiam que não poderia abrir mão desse antigo ingrediente social. Assim, o iluminismo tentou fundamentar a nova ordem através da razão, que era tanto individual como universal, uma luz presente em toda a humanidade. Mas a revolução francesa demonstrou o seu fracasso. No século XIX o nacionalismo teve sua oportunidade ao tentar restaurar, através da nação, a tão almejada unidade perdida entre objeto e sujeito. Mas a nação, assim como a cristandade, cobiçou o totalitarismo opressivo. O positivismo fracassou em sua busca por uma religião científica que orientasse uma sociedade, pois a ciência ainda se encontrava ausente da imensa maioria dos habitantes daquele mundo. Enfim, uma considerável proliferação de seitas esotéricas que nesta época saem da clandestinidade, apregoando uma reconciliação entre objeto e sujeito, não obteve a prosperidade almejada por conta do triunfo das ciências e as vitórias obtidas pelo cientificismo.

$\mathrm{Na}$ verdade, nenhuma destas propostas ou sistemas se estabilizou como substituto da antiga cristandade. Contudo, é no século XX, após a primeira guerra mundial, que os grandes impérios da cristandade começam a ruir e o ocidente se abre ao individualismo, quando o indivíduo se depara com as sociedades destruídas e as igrejas perdem o controle das massas populares. É ainda neste período que as massas rurais passam a emigrar para as cidades, trabalhando nas indústrias, aprendendo a ler e escrever, adquirindo direitos e ganhando certa visibilidade na vida pública, trazendo à tona a inevitável demanda entre o triunfante individualismo e a necessidade de uma ordem social estável, onde o maior problema a ser equacionado é tornar possível reunir sujeito e objeto, razão individual e necessidade social, liberdade e sacrifício pela sociedade. ${ }^{64}$

$\mathrm{Na}$ tentativa de respostas, surgem os totalitarismos almejando refazer uma humanidade unida que reconcilie liberdade e solidariedade, liberdade e progresso e a submissão a um bem comum com a liberdade individual. No entanto, seu

\footnotetext{
${ }^{64}$ José Comblin assevera que até 1914, de certo modo, toda a modernidade era um jogo que afetava no máximo $10 \%$ da população. O resto desta eram camponeses ou empregados domésticos que viviam na dependência da igreja e dos nobres, isto é, da cristandade, não participando do mercado e nem tendo direitos de cidadãos. Eram fiéis às suas igrejas. Cf. COMBLIN, José. Cristãos rumo ao século XXI. pp. 312-314.
} 
apelo à ordem termina por subordinar a liberdade individual à ordem da totalidade e seu golpe fatal é dado com a queda do comunismo soviético em 1989.

Portanto, o sentido ou aspirações mais profundas da modernidade também não foram expressos pelos totalitarismos, que são a emancipação do indivíduo e a libertação da economia, da política e da cultura da antiga cristandade. ${ }^{65}$

Se por um lado o processo de secularização trouxe uma construtiva reflexão sobre a imagem de Deus e responsável papel de sua igreja na sociedade, seu excesso, o secularismo, alçou o banimento da transcendência divina da vida humana, conforme argumenta Luis González-Carvajal:

Lo malo es cuando la secularización no se contenta con eliminar esa imagen falsa de Dios, sino que acaba arrasando cualquier sentido de ultimidad y de trascendencia de la vida, es decir, cuando cae en lo que hemos llamado "secularismo". En ese caso es necesario oponernos com todas nuestras fuerzas. El secularismo, que es un auténtico cáncer de la secularización, ha dado origen a una "cultura horizontal” incapaz ya de dirigir la mirada al cielo. ${ }^{66}$

Entretanto nunca se conseguiu erradicar o vazio espiritual da alma humana. E na pós-modernidade, a sede humana se encontra aflorada. A multiplicidade de produções literárias de cunho religioso constata isso, demonstrando também um apetite de acentuada configuração hedonista e narcísica. ${ }^{67}$

O sepultamento moderno da religião formal oficiado pela modernidade, na verdade, fez ressurgir como efeito “rebote”, uma religiosidade esotérica e supersticiosa, como descreve Isaltino Gomes Coelho Filho:

[...] Dotado de uma centelha espiritual, criado à imagem e semelhança de Deus, o homem sentiu falta do sagrado. Assim, a religiosidade se vingou da secularização, retornando, até mesmo de maneira agressiva, em forma de superstições grosseiras como cristais, pirâmides, gnomos, numerologia, florais de Bach, etc. ${ }^{68}$

Isto realça a atual tentativa do ser humano de se libertar de uma cultura religiosa com leis morais absolutas, através de uma religiosidade interiorizada, subjetiva e sem culpa ${ }^{69}$

\footnotetext{
${ }^{65}$ Cf. Ibid., p. 315.

${ }^{66}$ GONZÁLEZ-CARVAJAL, Luis. Ideeas y creencias del hombre actual. p. 51.

${ }^{67}$ Cf. GONDIM, Ricardo. Fim de milênio: perigos e desafios da pós-modernidade na igreja. São Paulo: Aba Press. 1999, p. 30.

${ }^{68}$ COELHO FILHO, Isaltino Gomes. A pós-modernidade, um desafio à pregação do evangelho. Disponível em: http://www.luz.eti.br/es_aposmodernidadeumdesafio.html. acesso em 18 de junho de 2012.

${ }^{69}$ Cf. GONDIM, Ricardo. Fim de milênio. p. 30.
} 
Segundo Maria Clara Bingemer, por conta da privatização da vida religiosa, coexistente e oriunda a autonomia outorgada ao ser humano moderno emergem inúmeras possibilidades seletivas a opção religiosa:

Hoje, assistimos à privatização da vida religiosa, que vai de par com a autonomia do homem moderno versus a heteronomia que regia o mundo teocêntrico medieval. Cada um compõe sua própria "receita" religiosa e o campo religioso se assemelha a um grande supermercado assim como, também, a um "lugar de trânsito" onde se entra e se sai. A modernidade não liquidou com a religião, mas esta ressurge com nova força e nova forma, não mais institucionalizada como antes, mas, sim, plural e multiforme, selvagem e mesmo anárquica, sem condições de voltar ao pré-moderno. ${ }^{70}$

Assim, o ser humano atual, já livre de amarras institucionais, peregrina em meio a inúmeras propostas religiosas, entregando-se ao desfrute da escolha pessoal, podendo inclusive, compor sua própria e sobmedida proposta religiosa. ${ }^{71}$

Ao conjunto de normas e verdades impostas pela subserviência heteronomica da cristandade, estabelecidas como necessárias à uma legítima experiência de fé pelo ser humano, sucedeu-se uma concreta autonomia de variadas opções, que avança difusamente a um universo religioso cada vez maior. $^{72}$

$\mathrm{Na}$ verdade, como consequência das crises do mundo objetivo e do esvaziamento da liberdade, tornou-se visível um retorno à religião. Todas as tentativas de refazer a unidade entre o objeto e o sujeito foram rejeitadas pela pósmodernidade, que desdenhou de todo projeto de longo prazo, deixando assim, o ser humano como sujeito de sua existência, entregue a uma considerável solidão.

A ciência atual não se empenha mais em apresentar um projeto de representação da realidade, mas multiplica-se em diversidade, perdendo assim, toda pretensão de síntese, o que também proporciona ao ser humano atual um imenso vazio. Vazio que o mesmo tem buscado suprir novamente através da religião, que sempre propôs uma visão de conjunto da realidade, certo conhecimento global. Por isso, embora para muitos a igreja ainda apareça como a defensora da moral e das relações tradicionais, que pouco se envolve com as tarefas comuns e militâncias em prol da liberdade do sujeito, também tem se reacendido um novo interesse pelo cristianismo.

\footnotetext{
${ }^{70}$ BINGEMER, Maria Clara. Faces e interfaces da sacralidade num mundo secularizado. p.17.

${ }^{71}$ Cf. Ibid.

${ }^{72}$ Cf. Ibid., p. 27.
} 
Em contra-partida, certo grupo de pessoas tem buscado uma solução existencial em outras religiões, principalmente as asiáticas: islamismo, budismo, hinduísmo e taoísmo, entre outras, onde se percebe considerável dificuldade de engajamento por causa de uma brusca ruptura de modelo cultural. Logo, como já mencionado, outros tem optado pelo esoterismo, já oriundo da gnose dos primeiros séculos, que sempre apresentou uma possibilidade de se viver uma espécie de cristianismo independente da cristandade.

Entretanto, o sujeito do esoterismo é o sujeito da gnose, que pelo conhecimento pretende alcançar sua salvação, entrando em si próprio, à procura do seu eu profundo, a fim de descobrir a unidade de tudo, onde encontre paz e salvação. Portanto, ele termina por se isolar das demandas existenciais do mundo exterior, falhando em reconciliar o sujeito com o objeto. ${ }^{73}$

\title{
2.3.3.
}

\section{A distensão individualista}

Em ruptura frontal com a ideologia de civilizações anteriores, configuradas de maneira holística com fundamento sagrado, o individualismo constitui um sistema de valores autônomos como explica o filósofo Gilles Lipovetsky:

\begin{abstract}
...o individualismo constitui um sistema de valores que põe o indivíduo livre e igual como valor central de nossa cultura, como fundamento da ordem social e política. Essa configuração de valores se afirma plenamente na história a partir do século XVIII, tornando-se o princípio primeiro da ordem pluralista e liberal... as regras da vida social, a lei e o saber não são mais recebidos de fora, da religião ou da tradição, mas construídos livremente pelos homens, únicos autores legítimos de seu modo de ser coletivo. Enquanto o poder deve emanar da livre escolha de cada um e de todos, ninguém deve ser mais coagido a adotar esta e aquela doutrina e submeter-se a regras de vida ditadas pela tradição. ${ }^{74}$
\end{abstract}

Um dado importante constatado por Lipovetsky é que quanto mais a cultura hiper-moderna tem-se centrado na autonomia individual, mais os indivíduos tem sentido em seu trabalho a heteronomia das pressões da globalização, tais como demissões e restrições financeiras oriundas de decisões longínquas muito além de sua alçada. Se por um lado o mundo do individualismo denominou um universo onde cada um é responsável por si mesmo, por outro, no entanto, tal indivíduo

\footnotetext{
${ }^{73}$ Cf. Ibid., pp. 320-323.

${ }^{74}$ LIPOVETSKY, Gilles. A cultura-mundo. pp.46-47.
} 
tem se sentido cada vez mais despossuído de sua própria vida por potências anônimas cuja autonomia da decisão se encontra muito além de seus domínios. ${ }^{75}$

Este, também é um momento de aflorada e virtual impossibilidade de se achar uma forma de expressão de identidade que tenha boa probabilidade de reconhecimento vitalício, o que resulta numa notória dificuldade em se adotar e manter-se fiel a qualquer identidade por muito tempo. ${ }^{76}$

O referido filósofo alerta também para o fato de que na escala histórica, uma segunda revolução do individualismo encontra-se em marcha, agora livre de ferrolhos tais como ordem familiar, ideologias revolucionárias e nacionalistas, controle disciplinar e moral autoritária, entre tantos outros dispositivos coletivos que contrariaram a afirmação plena e inteira do princípio de individualidade. ${ }^{77}$

Em geral, tais dispositivos manifestam-se atualmente como meios válidos ou úteis para a auto-realização pessoal. ${ }^{78}$ Dentre os referenciais citados, o que ainda provoca considerável sintoma nostálgico é a família e seu santuário perdido, local para as lutas entre tradição e modernidade. Uma gama de políticos e ativistas ainda hoje clama por um retorno à família tradicional. ${ }^{79}$

Segundo José Comblin o amor à família, à pátria e à igreja faziam com que tudo fosse sacrificado para o bem dessas formas de solidariedade. O indivíduo deveria então reprimir em nome do amor e da solidariedade toda aspiração individual. A tentativa em compatibilizar amor e liberdade acabou por gerar um drama, parecendo sinalizar uma contradição entre liberdade e solidariedade. Assim, aspirou-se a uma liberdade estruturalmente emancipada dos laços do amor, como descreve o referido teólogo: ${ }^{80}$

\footnotetext{
${ }^{75}$ LIPOVETSKY, Gilles. Futuro da autonomia e sociedade do indivíduo. In: NEUTZLING, Inácio; BINGEMER, Maria Clara; YUNES, Eliana.(Org.) O futuro da autonomia: uma sociedade de indivíduos? Rio de Janeiro: PUC-Rio; São Leopoldo: Unisinos, 2009, p. 64.

${ }^{76}$ BAUMAN, Zygmunt. O mal estar da pós-modernidade. p. 155.

${ }^{77}$ LIPOVETSKY, Gilles. A cultura-mundo. pp. 47.

${ }^{78}$ BARROS, Thiago Nunes. Desafios da fé e da razão na sociedade pós-moderna. Revista eletrônica Espaço teológico. Maio de 2010. Disponível em: Http://revistas.pucsp.br/index.php/reveleteo. Acesso em: 01 de maio de 2012.

${ }^{79}$ GIDDENS, Anthony. Mundo em descontrole. p. 63.

${ }^{80}$ COMBLIN, José. Cristãos rumo ao século XXI. p. 82. O Teólogo José Comblin explica que durante os séculos da cristandade, de forma geral entre os cristãos, o amor identificou-se muito com as formas espontâneas de solidariedade. Entretanto, estas não eram objetos de opções pessoais, mas imprescindíveis a todos os membros da comunidade humana de modo indiscutível. Segundo ele, a solidariedade universal dava-se na família, pois fora desta dificilmente se subsistiria, salvo numa condição mais ou menos irregular de soldado, prostituta, bandido ou mendigo. O indivíduo recebia tudo da família e lhe devia tudo; a segunda solidariedade era a da tribo, onde os que moravam no mesmo território falavam a mesma língua, tinham os mesmos costumes, o mesmo modo de viver e a mesma cultura, sentindo-se tão solidários que morriam na
} 
O individualismo apareceu em primeiro lugar em forma de empresa, e a empresa moderna foi se desenvolvendo. Em lugar de trabalhar na família, o sujeito forma uma empresa desligada de qualquer responsabilidade de família. A empresa está baseada no princípio de propriedade individual que vai prevalecer pouco a pouco e eliminar a propriedade familiar, tribal ou de igreja [...]. A empresa é uma associação de trabalhadores individuais que recebem o seu salário individual [...]. Na empresa não existe solidariedade, nem amor. Cada um cuida do seu e compete com todos, procurando vencer. A empresa é lugar de luta. ${ }^{81}$

Assim, ascende na sociedade um Homo individualis desenquadrado, liberto de imposições coletivas $^{82}$ que busquem seu comprometimento e militâncias individuais, embora ainda se apresente aberto a reuniões de grupo direcionadas a algum tipo de terapia pessoal ou de cuidado com o corpo, na verdade, ${ }^{83}$ um neoindividualismo do tipo opcional, desregulado, descompartimentado, uma "vida à la carte”, como descreve Lipovetsky:

As formas desse neo-individualismo centrado na primazia da realização de si são incontáveis. Paralelamente à autonomia subjetiva, ao hedonismo e ao psicologismo, desenvolve-se uma nova relação com o corpo: obsessão com a saúde, culto do esporte, boa forma, magreza, cuidados de beleza, cirurgia estética... manifestações de uma cultura tendencialmente narcisista. Claro que essas lógicas são desenvolvidas de maneira muito desigual em todo o globo, mas por toda a parte progride a dinâmica de individualização, com a autonomização da existência individual, cada vez mais voltada para si mesma, a busca de um bem-estar pessoal e consumidor. ${ }^{84}$

Este individualismo desenquadrado também tem desencadeado um considerável e profundo fenômeno afirmador de diferentes formas de comunitarismo, compostas por buscas étnicas, reivindicações identitárias e particularistas, novos movimentos religiosos e multiplicações de seitas entre outros, onde o indivíduo desenquadrado, solto, e agora ansioso, busca novos pontos de ancoragem. Um retorno do comunitarismo, que em nossos dias busca uma recomposição da identidade coletiva, pois para certos indivíduos torna-se extremamente difícil viver em um estado livre, sem nenhum enquadramento

guerra para defender a sua tribo; e por fim a última solidariedade dava-se na igreja ou na cristandade, mediante a união de todos os povos cristãos, de todos os que praticavam a mesma religião, sendo naquele tempo, a unidade da cultura assumida pela religião e a pertença à igreja cristã, o que criava o mais forte dos laços, capaz às vezes, de conseguir dedicação e consagração mais forte do que a família ou a tribo. Cf. COMBLIN, José. Cristãos rumo ao século XXI: nova caminhada de libertação. São Paulo: Paulus, 1996, pp. 40-42.

${ }^{81}$ Cf. Ibid., p. 84.

${ }^{82}$ Cf. LIPOVETSKY, Gilles. A cultura-mundo. p. 47.

${ }^{83}$ GONZÁLEZ-CARVAJAL, Luís. Educar en un mundo postmoderno.

${ }^{84}$ LIPOVETSKY, Gilles. Op.cit., p. 48. 
coletivo, havendo também a necessidade de integração comunitária, para sua participação emocional dentro da referida comunidade. ${ }^{85}$

Para Michel Maffesoli, na medida em que se considera a sincronia ou a sinergia das forças que agem na vida social, redescobre-se que o indivíduo não pode viver isolado, mas encontra-se ligado pela cultura, comunicação, lazer e moda. Assim, mesmo exibindo peculiaridades contemporâneas mantém-se o espírito de comunidade. O laço da reciprocidade é tecido entre os indivíduos pelo entrecruzamento das ações, das situações e dos afetos, os quais formam um todo. $^{86}$

Antes de qualquer determinação ou qualificação, a solidez e a força de uma cultura advêm da vital espontaneidade de um convívio entre as pessoas. ${ }^{87}$

Atualmente, os diversos modos de vida se estruturam mais a partir de uma multiplicidade de polos, pois são tributários de ocorrências, de experiências e de situações muito variadas, as quais agrupam os indivíduos por afinidade. O "amor louco" e o “acaso objetivo" do Surrealismo, o encontro e a “deriva” do situacionismo, acabam por capilarizar-se progressivamente no conjunto do corpo social. $^{88}$

Pode-se dizer que a partir da concepção que determinada época faz da alteridade é que se pode determinar a forma essencial de uma dada sociedade.

Coadunado à existência de uma sensação coletiva, encontra-se o desenvolvimento de uma lógica de rede. Logo, os processos de atração se farão por escolha. Assim, assiste-se à elaboração de uma espécie de socialidade eletiva, onde a própria religação é mais importante do que os elementos que são ligados. Logo, o fato de estar junto torna-se mais importante do que o objetivo a se atingir. $^{89}$

Entretanto, Maffesoli assevera que os relacionamentos desta socialidade não constituem um sinônimo de unanimidade, antes um exercício para o convívio ante a diversidade pessoal de cada membro do grupo eleito:

A pós-modernidade tende a favorecer, nas megalópoles contemporâneas, ao mesmo tempo o recolhimento no próprio grupo e um aprofundamento das

\footnotetext{
${ }^{85}$ LIPOVETSKY, Gilles. O futuro da autonomia: uma sociedade de indivíduos? p. 68.

${ }^{86}$ MAFFESOLI, Michel. O tempo das tribos: O declínio do individualismo nas sociedades de massa. Rio de Janeiro: Forense universitária, 2010, p. 140.

${ }^{87}$ Ibid., p. 141.

${ }^{88}$ Ibid., p. 147.

${ }^{89}$ Ibid,. p. 148.
} 
relações no interior desses grupos. Fica entendido que esse aprofundamento não é sinônimo de unanimismo, e tanto é assim que o conflito desempenhará aí seu papel. Aliás, não é essa a questão. Basta reter que a atração e a repulsa são causas e efeito do relacionismo. ${ }^{90}$

Vista por outro ângulo, o da erosão do espaço social pelo estético, a questão da relacionalidade é analisada por Bauman, asseverando-se que o espaço físico da cidade também é o território do espaçamento estético, onde predomina desigual distribuição de interesses, curiosidade e capacidade de suscitar diversão e prazer. Os resultados do espaçamento cognitivo e estético não coincidem. Os estranhos do espaço social/cognitivo podem ser objetos de intensa curiosidade como fontes de experiência e entretenimento. A tecnologia do espaçamento exigiria que a pessoa afastasse os olhos quando na companhia de estranhos. A tecnologia do espaçamento estético faz dos olhos a abertura primária pela qual os prazeres, que o espaço cheio da multidão tem a oferecer, podem ser assumidos. Os estranhos, com seus modos singulares e imprevisíveis, com a multiplicidade de suas variedades de aparências e ações, com sua capacidade de surpreender, são fonte particularmente rica de prazer para o espectador. Esteticamente, o espaço da cidade é um espetáculo em que o valor de diversão supera todas as outras considerações. O caráter inconsequente do controle estético é que torna seu prazer sem nuvens. ${ }^{91}$

Uma das exigências feitas ao indivíduo que adentra o mundo esteticamente espaçado é sua capacidade de produzir diversão. O valor da diversão deve se manter fresco e reabastecido constantemente de formas cada vez mais atraentes, precisando lutar contra a inevitável desvalorização pela familiaridade e enfado; só podem contar com estadia mais prolongada os outros que desenvolvem qualidade aditiva. Mas, nesse campo, drogas e dispositivos de alta tecnologia, desenhados com habilidade e com suprimento sem fim de sempre novos jogos, infiltram-se decisivamente em meros humanos. O proprietário do espaço estético tem o direito de recusar só por sua decisão serviço a fregueses não bem-vindos. Nenhuma negociação aqui, nenhum contrato, somente prazer mútuo, enquanto este dura. Enquanto o espaço social busca, mesmo que não alcance, estruturação, clareza de divisões, estabilidade de categorias, monotonia e repetitividade, previsibilidade e garantias a toda prova de que as expectativas serão realizadas, o espaçamento

\footnotetext{
${ }^{90}$ Ibid., p. 153.

${ }^{91}$ Cf. BAUMAN, Zygmunt. Ética pós-moderna. São Paulo: Paulus, 2003, pp. 192-193.
} 
estético busca indistinção e repartições móveis, o valor chocante da novidade, do surpreendente e do inesperado, expectativas que sempre se movem mais depressa e ficam na frente da realização.

O sociólogo polonês entende então que o declínio da união pelo casamento, a tendência constante a substituir os modelos mais estáveis e ortodoxos de família por várias formas de “viver juntos” todas episódicas e sem compromissos de permanência, o gosto pela convivência experimental, fragmentária e aventureira são todos efeitos colaterais da erosão do espaço social pelo estético, e da gradativa substituição dos critérios e mecanismos do espaçamento social pelos do espaçamento estético. ${ }^{92}$

Portanto, além da felicidade, atualmente a beleza tem sido uma das mais excitantes promessas modernas e um dos ideais que instigam o inquieto espírito hodierno e sua história pode ser considerada um paradigma na origem e desenvolvimento da moderna e líquida cultura do lixo. ${ }^{93}$

\subsection{4.}

\section{A angustia hedonista}

O individualismo pós-moderno encontra-se mergulhado numa cultura cotidiana dominada pela mitologia da felicidade privada e pelos ideais hedonistas, onde o prazer da boa alimentação, o prazer sexual e os cuidados com a imagem dão sentido à vivência presente, preferível a um futuro incerto. ${ }^{94}$

Gilles Lipovetsky explicita isto com propriedade quando diz:

A sociedade do objeto apresenta-se como civilização do desejo, prestando um culto ao bem-estar material e aos prazeres imediatos. Por toda parte exibem-se as alegrias de consumo, por toda a parte ressoam os hinos aos lazeres e às férias, tudo se vende com promessas de felicidade individual... Espalha-se toda uma cultura que convida apreciar os prazeres do instante, a gozar a felicidade aqui e agora, a viver para si mesmo; ela não prescreve mais a renúncia, faz cintilar em letras de neon o novo evangelho: "comprem, gozem, essa é a verdade sem tirar nem pôr". Essa é a sociedade de consumo, cuja alardeada ambição e liberar o princípio de gozo, desprender o homem de todo um passado de carência, de inibição e de ascetismo. Não mais injunções disciplinares e rigoristas, mas a tentação dos desejos materiais, a celebração dos lazeres e do consumo, o sortilégio perpétuo das felicidades privadas. ${ }^{95}$

\footnotetext{
${ }^{92}$ Cf. Ibid., pp. 205-206

${ }^{93}$ Cf. BAUMAN, Zygmunt. Vidas desperdiçadas. p. 140.

${ }^{94}$ Cf. GONZÁLEZ-CARVAJAL, Luís. Educar en un mundo postmoderno. .

${ }^{95}$ LIPOVETSKY, Gilles. A felicidade paradoxal: ensaio sobre a sociedade de hiper-consumo. São Paulo: Companhia das letras, 2007, p. 102.
} 
A atual intensa busca do indivíduo pelo prazer e felicidade acha resposta na indústria da experiência que se concretiza numa orgia de simulações, artifícios poderosamente convincentes e estímulos sensoriais destinados a produzir nos indivíduos diferentes sensações levando-os por vezes a viver momentos emocionais em ambientes hiper-realistas, estereotipados e climatizados, tais como parques temáticos, cinemas e teatros entre outros. ${ }^{96}$

Através de imagens do corpo reificado, fetichizado, modelizado como um ideal a ser atingido, as mídias fornecem suporte ao que pode ser chamado de “ilusões do eu". 97

O culto ao corpo recebe pesado investimento e sustentáculo midiático e industrial. A mídia viabiliza a temática afeiçoando-a ao dia a dia das pessoas, atualizando descobertas tecnológicas e científicas, e impingindo novas tendências. ${ }^{98}$

A ilusão desta ansiosa realidade é assim descrita por Denise Bernuzzi:

A multiplicação de imagens sobre corpos saudáveis e sempre belos é bem mais rápida do que a produção real de saúde e beleza no cotidiano. A corrida rumo à juventude é hoje uma maratona que alcança jovens e idosos de diversas classes sociais, mas estes não conseguem ver o pódio, porque se trata de uma corrida infinita. Ignoram quem compete com quem, talvez porque a principal competição se passe dentro de cada um, entre o corpo que se é e o ideal de boa forma que cada um sonha. ${ }^{99}$

Padrões de beleza e de comportamento ganham espaço de protagonismo ante a uma imprensa difusora de informações referentes ao universo do corpo. ${ }^{100}$

Na desenfreada corrida pública pela beleza, em busca de almejado ideal estético, corpos tentam saltar obstáculos de imperfeição e velhice, enquanto indústrias de beleza materializam novas tendências através de produtos e objetos consumíveis. $^{101}$

\footnotetext{
${ }^{96}$ Cf. Ibid., p. 64.

${ }^{97}$ Cf. SANTAELLA, Lúcia. Corpo e comunicação: sintoma da cultura. São Paulo: Paulus, 2004, p. 125.

${ }^{98}$ Cf. Ibid., p. 127.

99 SANT'ANNA, Denise Bernuzzi de. Corpos de Passagem: ensaios sobre a subjetividade contemporânea. São Paulo: Estação liberdade, 2001. p. 70.

${ }^{100}$ Cf. SANTAELLA, Lúcia. Corpo e comunicação: sintoma da cultura. São Paulo: Paulus. 2004, p. 127.

${ }^{101}$ Cf. Ibid., pp. 127-128.
} 
Configura-se atualmente, portanto, um corpo exorbitante especulado midiaticamente, que prolifera na multiplicação desmesurada de imagens fotográficas e nos desdobramentos virtuais favorecidos pelas novas tecnologias. ${ }^{102}$

Uma cultura de felicidade possibilitada por um rigoroso conjunto de normas de auto-domínio e vigilância como explica Lipovetsky:

A era da felicidade de massa celebra a individualidade livre, favorece a comunicação e multiplica as escolhas e opções ao infinito. Entretanto, isso não equivale a dizer que nenhum padrão seja mais aceito. Com efeito, a cultura da felicidade não seria concebível sem um conjunto de normas, de informações técnicas e científicas que predispõem a um constante exercício de autodomínio e de vigilância sobre si. Após o imperativo categórico, o imperativo narcisista é celebrado sem trégua pela cultura saudável e esportiva, estética e dietética. Manter a forma, lutar contra as rugas faciais, zelar por uma alimentação sadia, bronzear-se, não perder a silhueta, alongar-se: a felicidade individualista é indissociável de um extraordinário forcing no esforço de dinamização, de manutenção, de gerenciamento otimizado de si. A ética contemporânea Ada felicidade não é só consumista, mas essencialmente ativista, construtivista. ${ }^{103}$

Como pano de fundo a toda esta disciplina social a que o corpo acaba por se submeter, oculta-se a subserviência a um ideal narcísico ditador a uma regra única: a do investimento e cultivo de uma espécie de amor egocêntrico, tão emblemático à sociedade contemporânea. ${ }^{104}$

Christopher Lasch descreve o novo narcisista da seguinte forma:

O novo narcisista é perseguido não pela culpa, mas pela ansiedade. Ele procura não infligir suas próprias incertezas nos outros mais entregar um sentido para vida... Ganancioso, no sentido de que seus desejos não têm limites, ele não acumula bens e provisões para o futuro, como o fazia o ganancioso individualista da economia do século XIX, mas exige imediata gratificação e vive em estado de desejo, desassossegado e perpetuamente insatisfeito. ${ }^{105}$

Está em tela então uma sociedade profundamente marcada pela competitividade hedonista e narcísica conduzida por uma gestão utilitarista do capital-corpo através da otimização da forma e da saúde, procurando sempre elevar a emoção ao extremo. Típicas atitudes de quem está formando sua personalidade em crise com a própria história. ${ }^{106}$

\footnotetext{
${ }^{102}$ Cf. Ibid., p. 128.

${ }^{103}$ LIPOVETSKY, Gilles. A sociedade pós-moralista: o crepúsculo do dever e a ética indolor dos novos tempos democráticos. São Paulo: Manole, 2005, pp. 33-34.

${ }^{104}$ Cf. Ibid., p. 130.

${ }^{105}$ LASCH, Christopher. A cultura do narcisismo. Rio de Janeiro: Imago, 1983, p. 14.

${ }^{106}$ Cf. LIPOVETSKY, Gilles. A sociedade pós-moralista. p. 89.
} 
Numa rede relacional hodierna onde emergentes temáticas perpassam por saúde e cosmética, o corpo traduz-se em uma importante marca identitária, podendo ser modificado e exposto com considerável liberdade. Assim, a ansiosa expectativa de ser fotogênico sugere às pessoas considerável solidão ante a responsabilidade devida a tal cobrança. ${ }^{107}$

Entretanto, como Lúcia Santaella observa, a computação gráfica de hoje tem atenuado significativamente algumas exigência estéticas não comparecidas pela própria natureza do corpo:

O crescente aprimoramento da fotografia, desde o início do século XIX até os nossos dias, correspondeu ao aumento de sofisticação das formas de registro do corpo. Com a manipulação da imagem fotográfica hoje permitida pela computação gráfica, corpos podem ser transformados a bel prazer, defeitos apagados, corrigidos, a anos luz de distancia dos tradicionais valores da fidelidade fotográfica [...]. os rostos e os corpos das atrizes e das modelos atingem o paroxismo da perfeição [...], seus corpos são tão perfeitos que parecem cobertos de verniz, de uma película transparente que vitrifica o corpo, um corpo sem poros, sem exsudação, nem excreção, funcionalizado como um revestimento de celofane, exibindo a imortal juventude da simulação. ${ }^{108}$

Parece que o ser humano destes dias aspira algum tipo de narcisismo elitista, como descreve Denise Bernuzzi parafraseando o referido sentimento:

[...] a liberdade se instala como expectativa de poder uma dia reconstruir o corpo como se quer, de ingressar nessa elite ilustrada pela mídia, de homens e mulheres livres e ricos, que parecem dizer todo o tempo: "meu corpo corresponde àquilo de que gosto, àquilo que sou, independentemente de minhas heranças genéticas, das minhas filiações culturais e de classe, do meu estado civil e das maneiras pelas quais eu ganho dinheiro; minha casa tem a minha cara, [assim como] minha banheira e minhas roupas não cessam de expressar aquilo que sou. ${ }^{109}$

O corpo foi transformado em um território privilegiado de experimentações sensíveis, dotado de certa inteligência não situada apenas no cérebro. Para isso, foi necessário desligá-lo da geografia e da história local e elevá-lo a um status pessoal em suas relações com o sagrado, libertando-o ainda, de tradições e moralismos seculares, conferindo-lhe uma honra como de alma. Desde então foi fácil considerá-lo uma instigante fronteira a ser vencida, explorada e controlada. ${ }^{110}$

\footnotetext{
${ }^{107}$ Cf. SANT’ANNA, Denise Bernuzzi de. Corpos de Passagem. p. 68.

${ }^{108}$ SANTAELLA, Lúcia. Corpo e comunicação. p. 129.

${ }^{109}$ SANT’ANNA, Denise Bernuzzi de. Op.cit., p. 69.

${ }^{110}$ Cf. Ibid., p. 70.
} 
Entretanto, vale lembrar que entre os cobiçados modelos exibidos e o corpo vivo inserido nas realidades diárias de fadigas, suores, cheiros, variadas demandas cotidianas, dores, impulsos apaixonados e desejos, estabelece-se uma tensão cultural da qual o corpo é o principal objeto de análise. ${ }^{111}$

Gilles Lipovetsky identifica o surgimento de um grande paradoxo no autônomo universo hedonista consumidor: uma multiplicação das psicopatologias dos transtornos de personalidade e do mal-viver advindos das próprias dificuldades existenciais cotidianas. Neste mundo da posse de si e entrega a si próprio, em meio a ambientes de ansiedade, estresse e consumo de tranquilizantes, o risco de pessoas desenvolverem episódios depressivos e tentarem o suicídio é significativamente alarmante, pois o universo da autonomia hodierna também é o universo da fragilidade psicológica cada vez mais generalizada. Soltaram-se as amarras do ser humano, abalaram-se os alicerces, e os artelhos de sua personalidade titubeiam ante o peso das incertezas e fragilidade emocional. Sua vulnerabilidade psicológica denuncia que ele está em guerra relacional consigo mesmo.

Apesar da predominância atual de uma cultura de fruição do instante, onde se almeja fruir e usufruir lazer e abundância imediatos sem adiamentos, observase em contrapartida, a clara expressão de uma cultura polifóbica, um sentimento de insegurança que está por toda a parte oriundo de complexas demandas sociais como desemprego, poluição, segurança urbana, doenças, idade e peso entre outras. Numa sociedade em que quase tudo e problemático, percebe-se a especificação de um hedonismo de perfil mais ansioso e reflexivo que eufórico. ${ }^{112}$

\subsection{5.}

\section{A miséria consumista}

Como já mencionado, objetos e experiências de todos os tipos são transformados em mercadorias gerando vidas dedicadas ao consumo e suscitando nos seres humanos desejos variados.

\footnotetext{
${ }^{111}$ SANTAELLA, Lúcia. Corpo e comunicação. p. 131.

${ }^{112}$ LIPOVETSKY, Gilles. Futuro da autonomia e sociedade do indivíduo. pp. 64-65. Segundo Gilles Lipovetsky, nos países desenvolvidos, entre 10 e 15\% da população sofrem de depressão. Uma pessoa em cada cinco corre o risco de viver um episodio depressivo maior ao longo de sua vida. Cf. Ibid., p. 64.
} 
Segundo Guy Debord, precursor de toda uma análise crítica da sociedade de consumo, a referida disposição sistemática origina-se nos meios de comunicação de massa onipresentes nesta sociedade coisificada, definida por ele mesmo como “a sociedade do espetáculo”. Mais do que qualquer tipo de complementação ao mundo, o espetáculo é o resultado e o projeto do modo de produção existente. Sob as mais variadas formas particulares, tais como informação, propaganda, publicidade e consumo de divertimentos, ele constitui o modelo atual de vida dominante na sociedade. O espetáculo é a afirmação onipresente da escolha feita desde a produção, uma escolha que gerará um desejo de consumo. Na verdade, as condições e os fins do sistema existente encontram a devida justificativa nas formas e conteúdo desse espetáculo ${ }^{113}$ como ele explica abaixo:

A notável expansão do mercado envolve atualmente narrativas e produções estéticas. Através do espetáculo, a fabricação de eventos familiariza todo mundo em suas poltronas com ídolos, celebridades e estilos e promove uma vasta "solidariedade" entre as multidões nas maneiras de vestir, desejar e se comportar. ${ }^{114}$

Na referida obra clássica Debord registrou a falsificação do mundo através da mídia e a substituição das vivências diretas dos seres humanos pela condição de espectador e pelo consumo passivo de imagens. ${ }^{115}$

Segundo Zygmunt Bauman, o ser humano que vem optando por relacionarse através de comunidades virtuais, perdendo assim sua capacidade de estabelecer novas, estáveis e substanciais relações pessoais reais:

\begin{abstract}
Absortos em perseguir e capturar as ofertas do tipo "entre agora" que piscam nas telas do computador, estamos perdendo a capacidade de estabelecer interações espontâneas com pessoas reais...Tampouco podem essas "comunidades virtuais" dar substância à identidade pessoal - a razão básica para procurá-las. Pelo contrário, elas tornam mais difíceis para as pessoas chegar a um acordo com o próprio eu. ${ }^{116}$
\end{abstract}

A atual sociedade de consumo tem como uma de suas características principais a efemeridade. Pois, se na antiga era moderna a vida consistia de uma recitação diária da duração infinita de todas as coisas, com exceção da existência mortal, atualmente a liquidez existencial a faz consistir de uma recitação diária de transitoriedade universal, pois nada no mundo se destina a permanecer. Os objetos

\footnotetext{
${ }^{113}$ Cf. DEBORD, Guy. A sociedade do espetáculo. Rio de Janeiro: Contraponto, 1997, p. 11.

${ }^{114}$ Ibid., pp. 14-15.

${ }^{115}$ Cf. FRIDMAN, Luís Carlos. Vertigens pós-modernas. p. 24.

${ }^{116}$ BAUMAN, Zygmunt. Identidade. Rio de Janeiro; Zahar, 2005, p. 31.
} 
úteis e indispensáveis de hoje são, com pouquíssimas exceções, o refugo de amanhã. Nada é necessário de fato, nada é insubstituível. O que se produz já nasce em contagem regressiva para morte iminente, seu prazo de validade já vem afixado. Até mesmo as escolhas são revogáveis e descompromissadas, e não duram o bastante para alcançar um ponto sem retorno. Tudo é dispensável até segunda ordem. Esta é a civilização do excesso, superfluidade, refugo e remoção. $^{117}$

Gilles Lipovetsky assim caracteriza a atual sociedade de consumo:

Pode-se caracterizar empiricamente a "sociedade de consumo" por diferentes traços: elevação do nível de vida, abundância das mercadorias e dos serviços, culto dos objetos e dos lazeres, oral hedonista e materialista etc... A sociedade centrada na expansão das necessidades é, antes de tudo, aquela que reordena a produção e o consumo de massa sob a lei da obsolescência, da sedução, e da diversificação, aquela que faz passar o econômico para a forma moda. ${ }^{118}$

A cultura consumista atual consiste primordialmente na negação enfática da vantagem de todo e qualquer adiamento da satisfação. Ela degrada a duração e exalta a efemeridade erguendo o valor da novidade acima do valor da permanência. O espaço de tempo que separa a vontade de sua realização, bem como entre a percepção da utilidade das posses adquiridas e sua completa inutilidade e rejeição, foi reduzido drasticamente. $\mathrm{O}$ ardente desejo de apropriação do ser humano atual tem a mesma medida de intensidade de sua impulsiva decisão de se desfazer do objeto conquistado. A atual cultura consumista tem como marcas características a velocidade, o excesso e o desperdício. ${ }^{119}$

Neste universo econômico onde a maior constante é uma variante e todos os resultados são dízimas demarcadas por vírgulas, fragmentos de uma conta de consumo que nunca se encerra exata, o crédito e a oportunidade de assumir uma nova dívida são considerados tão necessários e assim reconhecidos, que têm sido oferecidos com muita alegria e entusiasmo, acelerando e aproximando a satisfação dos desejos e impulsos do ser humano hodierno, simplificando assim a remoção de coisas não mais ambicionadas, ao mesmo tempo em que abrevia o período de tempo entre o nascimento de novos desejos, sua satisfação e remoção, o que também acelera a fragilização do referidos desejos, bem como sua substituição

\footnotetext{
${ }^{117}$ Cf. BAUMAN, Zygmunt. Vidas desperdiçadas. p. 120.

${ }^{118}$ LIPOVETSKY, Gilles. O Império do efêmero: A moda e seu destino nas sociedades modernas. São Paulo: Companhia das letras. 2009, p. 184.

${ }^{119}$ Cf. BAUMAN, Zygmunt. Op.cit., p. 111.
} 
pelo ressentimento e a rejeição. De modo inevitável, a expectativa de vida dos objetos de desejo também é abreviada, e estes rapidamente conduzidos à pilha de lixo. O crédito e o débito, portanto, são as parteiras do refugo. ${ }^{120}$

Como Alfonso Garcia Rubio descreve, este ser humano tem sua qualidade de vida valorada por sua capacidade de consumo:

O ser humano é radicalmente instrumentalizado, reduzido que é a mera função de mercado; o ser humano é visto simplesmente como consumidor potencial...Uma competição feroz orienta a vida de homens e mulheres, deixando de lado valores tais como a solidariedade, a colaboração, entre outros...Valioso econômica e socialmente, é só o homem ou a mulher que têm capacidade para consumir nesse maravilhoso mercado mundial. Essa é a nova bem-aventurança: bem aventurado aquele que pode consumir, e mais bem-aventurado ainda aquele que pode consumir mais!...Naturalmente quem não pode consumir é deixado de lado, faz parte da massa descartável. ${ }^{121}$

Atualmente uma auto-imagem projetada encontra mais acolhimento que a experiência ou as habilidades adquiridas. Diferentemente do predomínio crivador do século XIX, pessoas são julgadas por outras de seu convívio secular mais em virtudes de suas posses, roupas e outros adereços supérfluos do que por seu caráter, assim, o ser humano pós-moderno tem sido levado a uma auto-afirmação constante. $^{122}$

Samuel Escobar assevera que esta forte febre de consumo se estendeu até o campo religioso:

Recordemos que uma nota desta religiosidade contemporânea é que a religião se tem tornado uma mercadoria que pode ser exposta e oferecida como o que acontece num supermercado, e que os fregueses pagam ou deixam, conforme lhes convenha ou lhes agrade. ${ }^{123}$

Refletindo sobre o impulso consumista pós-moderno, é importante destacar que se nos anos do pós-guerra figuravam na sociedade como elementos básicos ao conforto, bens como o automóvel, a televisão e os eletrodomésticos, almejados como principais promessas de conforto, atualmente insuficientes a tal objetivo, crescem significativamente hoje, no que tange a temática da qualidade de vida, o desejo de uma melhor moradia, a preservação do meio ambiente, a urbanização, a decoração de interiores, a elaboração de jardins, e o culto ao patrimônio, passando

\footnotetext{
${ }^{120}$ Cf. Ibid., pp. 137-138.

${ }^{121}$ RUBIO, Alfonso Garcia. Unidade na pluralidade. pp. 49-50.

${ }^{122}$ Cf. GONDIM, Ricardo. Fim de milênio. p. 33.

${ }^{123}$ SALINAS, Daniel; ESCOBAR, Samuel. Pós-modernidade: novos desafios à fé cristã. São Paulo: ABU. 1998, pp. 74-75.
} 
assim, de um conforto quantitativo e técnico a um conforto mais qualitativo, que envolve qualidades sensoriais, moda, estética, cultura e emoção. ${ }^{124}$

Ao refletir mais profundamente sobre o contexto da veloz efemeridade socio-existencial humana, Bauman nos surpreende, indo mais além, observando que, uma parte crucial de qualquer fé consiste no investimento de valor em alguma coisa mais durável do que a efêmera e endêmica mortalidade da vida individual, algo que resista ao impacto erosivo do tempo. Segundo ele, a vida poderá ser vivida de forma tamanha que a mortalidade do indivíduo seja transcendida. Assim, o traço deixado pela vida não será apagado por completo. Pois, de acordo com o sociólogo, apesar de a fé ser uma questão espiritual, só poderá manter-se firme e necessária, se ancorada no mundo, na existência, onde suas amarras penetram fundo na vida cotidiana. ${ }^{125}$

Na sociedade atual, onde a vida se manifesta de forma fragmentada, vivida em episódios e eventos desconectados, a insegurança é o ponto do desmoronamento existencial. Tal sociedade carece urgentemente de algo que venha a restaurar sua fé em verdadeiros valores estáveis e duráveis. ${ }^{126}$

Para o Filosofo e Teólogo Andrés Torres Queiruga duas tentações terríveis que ainda continuam assolando a humanidade são o "desânimo” daquele que se sente derrotado pelo fracasso, e entrega-se ao desencanto e à apatia, esquivando-se assim, por muitas vezes, do sofrimento alheio e o "absolutismo", disposto a sacrificar milhões de vidas hoje, por uma convicção ilusória de futuro. Entretanto, apesar da pós-modernidade ter reconhecido lucidamente o perigo absolutista, enveredou-se excessivamente pelas veredas de certo desânimo pessimista pervertendo a possibilidade de uma postura práxica equilibrada ante as difíceis tensões relacionais humanas. O que, na percepção de Queiruga, propicia fecundo e equilibrado aprendizado:

Poder-se-ia afirmar coisa semelhante a respeito da dificuldade tão atual de encontrar saída humanamente equilibrada ao dilema relativismo-absolutismo nos valores morais, ou à tensão tolerância-intolerância-indiferença nas relações sociais;...devemos, os cristãos e cristãs, esforçar-nos para tirar lições em prol de equilíbrios criativos que deveras ajudem a humanidade. ${ }^{127}$

\footnotetext{
${ }^{124}$ Cf. LIPOVETSKY, Gilles. Futuro da autonomia e sociedade do indivíduo. pp. 66-67.

${ }^{125}$ Cf. BAUMAN, Zygmunt. A Sociedade individualizada. p. 200.

${ }^{126}$ Cf. Ibid., p. 202.

${ }^{127}$ QUEIRUGA, Andrés Torres. Um Deus para hoje. São Paulo: Paulus, 1998, pp. 52-53.
} 
Também é preciso salientar que a pós-modernidade trouxe consigo as percepções e qualidades como: uma propensão a uma espécie de humildade por parte de quem percebeu o erro em que incidiu a pretensão moderna quando arrogou-se a busca de um saber pleno; a evidência de uma sede por uma experiência espiritual, advinda por efeito colateral de um antigo e arrogante empirismo ressecado antes predominante; ante um conhecimento para além das possibilidades humanas, a constatação, abertura e viabilização da fé como mais adequado veículo de esperança, abertura que se mantinha fechada há centenas de anos. $^{128}$

Sem duvida, o cristianismo tem muito a contribuir para o atenuamento da referida tensão, pois em sua típica dialética da cruz-ressurreição, aprendeu a tirar valores absolutos do fracasso mantendo viva uma humilde, realista e diligente esperança de vida. Também, muito além de um discurso pragmático regulador à vida social, econômica e política, ele poderá apregoar um retorno cristão aos valores mais fundamentais, que incluem primordialmente o valor absoluto do ser humano; proporá como critério último do agir não o ganho próprio individual ou grupal, mas o serviço dirigido a todos e ainda na busca de mecanismos que introduzam a gratuidade do amor evangélico, um sensato alargamento e humanização da racionalidade instrumental transpassando-as com critérios de responsabilidade e compaixão solidária. ${ }^{129}$

Na realidade, todo o pluriforme código descrito deste ser humano pósmoderno até aqui, manifesta-se de forma mais desafiadora que adversária, urgindo a um comparecimento teológico-pastoral não somente apaixonado mais responsavelmente relevante por sua contextualização, como discerne Mario de França Miranda:

Estamos diante de um auditório bastante diversificado, com estruturas mentais bem diferentes, com demandas plurais e específicas, com linguagens e ethos dessemelhantes, que desafiam os proclamadores da palavra a encontrar um discurso que seja entendido por todos e, sobretudo, que possa entrar na vida real dos ouvintes, estruturando-a de dentro. ${ }^{130}$

\footnotetext{
${ }^{128}$ Cf. MCLAREN, Brian D. A igreja do outro lado. pp. 246-247.

${ }^{129}$ Cf. Ibid., pp. 53-58.

${ }^{130}$ MIRANDA, M. F. A igreja numa sociedade fragmentada: escritos eclesiológicos. São Paulo: Loyola, 2004, p. 264.
} 
Portanto, mais do que um momento diverso e desafiador, trata-se de uma emergente oportunidade à reflexão sobre o Kerygma do Reino. 


\section{3}

\section{O kerygma do caminho em Jürgen Moltmann}

Nesse segundo capítulo iremos refletir sobre o Cristo do caminho de Jürgen Moltmann, sua proposta de vida aos seres humanos que se encontram a caminho em meio às importantes questões existenciais de nossa época.

Trata-se de uma opção pela vida e pelo ser humano, anunciada pelo Cristo peregrino, o homem de Nazareth. Aquele que desconcertou os orgulhosos líderes religiosos de sua época ao ensinar-lhes o verdadeiro valor da graça de Deus, que preparou "mesas" aos excluídos e proclamou liberdade aos cativos de perversos sistemas opressores. O Deus encarnado na existência humana, vulnerável e empenhado no exercício didático do amor-serviço aos seres humanos que ele visa regenerar.

A atualizada leitura moltmanniana do Kerygma denota uma profunda percepção sobre o esvaziamento, a sensibilidade e a solidariedade de Deus em Jesus Cristo. Um encontro entre a Cristologia e a Cristoprática, demonstrando que o verdadeiro conhecimento de Jesus se dá no trilhar do seu caminho existencial, quando a exemplo dos cristãos da igreja primitiva, refazemos o itinerário de vida do Mestre, seguindo as suas pegadas.

\section{1. \\ O caminho da graça de Deus}

Na época de Jesus os rabinos ensinavam que os homens deveriam tomar sobre si o jugo de um reino que tivesse a lei como norma da vontade de Deus. ${ }^{131}$ A base da espiritualidade judaica consistia na obediência a Deus segundo as normas de sua Lei. Objetivamente, sua observância definiria condenação ou salvação ao homem. Em sua justiça Deus recompensaria o homem de acordo com a sua fidelidade à Lei. Entretanto, não possuindo um exato conhecimento da Lei, muitos entre o povo encontravam-se mal situados ante a tão almejada salvação. Tal idéia erguia uma barreira, um muro de Lei impessoal entre o Deus vivo e o ser humano, com objetivo de determinar através de cálculos exatos a noção judaica de recompensa, méritos e certeza da salvação. ${ }^{132} \mathrm{O}$ farisaísmo de sua época não

\footnotetext{
${ }^{131}$ Cf. LADD, George Eldon. Teologia do Novo Testamento. São Paulo: Hagnos, 2001, p. 68. ${ }^{132}$ Cf. SCHILLEBEECKX, Edward. Jesus: a história de um vivente. São Paulo: Paulus, 2008, p. 156.
} 
reconhecia o seu pecado e tampouco, na demanda retributiva, a necessidade da misericórdia divina. Antes, persistia no aguardo do salário correspondente à justiça própria, ${ }^{133}$ fugindo constantemente ao encontro pessoal, imprevisível e desconcertante com o Deus da vida, onde ao invés de obras apenas, fazia-se necessária a oferta de si mesmo. ${ }^{134}$

Jesus atacou frontalmente a falsa espiritualidade através de sua parábola sobre o servo inútil, que mesmo submisso ao seu senhor, o pai de família, e disponível a qualquer serviço solicitado, não gozava de nenhum direito a remuneração, demonstrando com isso, que o fiel e dedicado israelita também não teria direitos a reivindicar, traduzindo assim a mais alta personalização do ser humano. Assim, ele destrona a Lei de seu caráter objetivo como obstáculo entre Deus e o ser humano e o põe novamente em relacionamento direto com Deus, reportando-se submissamente a Ele. Surge então, uma graça que ultrapassa a remuneração pura e formal por serviços prestados, que põe de lado cálculos, salários e agradecimento, onde o ser humano passa a buscar um relacionamento pessoal com Deus, que gera por consequência natural, abundante recompensa de emocionante gratuidade. ${ }^{135}$

Tal gratuidade foi também apregoada na essência da grande ruptura de Jesus para com o pensamento zelote, onde seu anúncio transcende a antecipação do futuro pelo próprio Deus e seu princípio de não violência. Ele consiste antes de tudo, de sua liberdade sobre o legalismo que alimentava naqueles zelotes a ardente expectativa do último juízo, mediante guerra santa sobre os inimigos de Deus e de Israel. Enquanto aguardavam um reino instaurado por violência e coerção militar, Jesus apregoava sua antecipação por concessão de direito divino mediante a graça de Deus. Essa gratuidade foi ponto nevrálgico de todo o embate teológico. ${ }^{136}$

Apesar do crítico cenário de carestia econômica, servidão política e opressão religiosa, Jesus esvaziou paradigmas comuns de abstinência adotados pelo farisaísmo como responso coerente ao momento nacional em que vivia o povo judeu. Assim, taxado de “comilão e beberrão” (Lc. 7,34), promovia banquetes aos seus discípulos ao invés de incentivá-los à prática do jejum. Entre

\footnotetext{
${ }^{133}$ Cf. RUBIO, Alfonso Garcia. O encontro com Jesus Cristo vivo: um ensaio de cristologia para os nossos dias. São Paulo: Paulinas, 2007, p. 44.

${ }^{134}$ Cf. Ibid., p. 46.

${ }^{135}$ Cf. SCHILLEBEECKX, Edward. Jesus. pp. 156-157.

${ }^{136}$ Cf. MOLTMANN, Jürgen. O Deus crucificado: a cruz de Cristo como base e crítica da teologia cristã. São Paulo: Academia cristã, 2011, p. 182.
} 
os seus discípulos se encontravam pecadores e publicanos, estes últimos profundamente odiados pelos fariseus e zelotes por seus serviços prestados a forças opressoras romanas, o que fazia ruptura e distinção legal entre amigos e inimigos, judeus e samaritanos, bem como outros tipos de segregação socioreligiosa peculiarmente farisaicas. Sua vivência da fé fugia a todo aquele ascético estilo de vida de cunho socio-revolucionário zelote, assemelhando-se mais a uma alegre e conclamadora festa de núpcias. Afinal de contas, o noivo já havia chegado como descreve Joachim Jeremias:

As núpcias começaram, o noivo já foi recepcionado, ressoa o júbilo das núpcias por toda parte, os hóspedes estão reclinados para o banquete festivo - quem poderia jejuar nestas circunstâncias? As núpcias são símbolo corrente para significar o tempo da salvação. Este já se iniciou, agora mesmo. ${ }^{137}$

Todavia, para os Zelotes tal comportamento nunca poderia demonstrar verdadeira expressão de comunhão com um Deus que conhecia muito bem a miséria do seu povo naqueles dias. ${ }^{138}$ Como mensageiro de Deus, Jesus anuncia o “não radical” de Deus contra a história do sofrimento humano, desejando mostrar que o real sentido da história, ainda que num espectro escatológico, é paz, alegria, satisfação e salvação. ${ }^{139}$

Embora Jesus condenasse toda a injustiça social, ele nunca conclamou os pobres e oprimidos de sua época a uma vingança contra os seus opressores. Sua justiça seria antecipada pela graça e não pela força aspirada pelos zelotes. Sua revolução seria proporcionada mediante a desinstalação do sentimento de violência pelo amor, na bem-aventurança dos que promovem a paz, extrapolam o padrão de opressão e não se preocupam com a conquista do poder, aqueles que amam os seus inimigos e fazem o bem aos que os perseguem. Essa foi a sua revolução. Uma revolução de fé em Deus e no seu bem, do abandono do legalismo obsoleto à verdadeira justiça divina por ele proclamada, e de uma justiça escatológica mediante a graça que liberta os fracos e oprimidos das utópicas visões de vingança e sonhos de onipotência. Seu Kerygma não revoluciona sistemas políticos externos ao homem, mas o próprio interior humano e suas expectativas de libertação. Assim, aos pecadores: zelotes ou publicanos,

\footnotetext{
${ }^{137}$ JEREMIAS, Joachim. Teologia do Novo Testamento. São Paulo: Editora Teológica, 2004, p. 172.

${ }^{138}$ Cf. MOLTMANN, Jürgen. O Deus crucificado. p. 183.

${ }^{139}$ Cf. SCHILLEBEECKX, Edward. Jesus. p. 170.
} 
judeus ou samaritanos, e ainda posteriormente, judeus ou gentios é concedida a justificação pela graça. ${ }^{140}$

Analisando o perfil de imagem do "Deus das parábolas" proclamado por Jesus, Edward Schillebeeckx chama-nos a atenção para algo que ultrapassa uma realidade puramente comercial ou retributiva, uma misericórdia e clemência humanizadoras que acentuam a certeza do interesse do Deus do Reino pelo bem dos seres humanos:

Em termos de religiosidade geral, o "Deus das parábolas” aparece como o todopoderoso (Lc 12,20; 17,7-10), que como realístico homem de negócios exige "rendimento" de seus súditos (Mt 25,14-30), mas ele é também e sobretudo, misericordioso e clemente (Lc 18,10-14; Lc 18,7), consolador (Lc 16,19-31) e até incrivelmente magnânimo (Mt 18,23-35; 20,1-16; Lc 15,20-32); dá generosas recompensas (Mt 35, 21-23), não de acordo com os resultados, mas segundo a sua própria bondade (Mt 20,15) e é insuperável em longanimidade (Lc 13,6-9; Mt 13,24-30). Nisso reencontramos o Deus de Jesus, do reinado de Deus, que só pensa no que é bom para a humanidade. ${ }^{141}$

Jesus proclama e instala um Reino diferente cujo programa social se baseia num “jubileu” permanente (Lc. 4,18; Is. 61,1,2), onde dívidas são perdoadas, o serviço forçado é anulado e a justiça de Deus é restabelecida no meio do povo. Parábolas como a do “credor incompassível” (Mt. 18,21-35) e do “mordomo injusto" (Lc. 16,1-13), bem como a própria oração do "Pai nosso" e o sermão da planície que orienta nos endividados a emprestarem sem receberem de volta e a perdoarem para serem perdoados, demonstram a definitividade e radicalidade do seu reino de jubileu, que muito mais do que um ano, evidencia o início de uma era de misericórdia para com o próximo, um sábado messiânico sem fim, ${ }^{142}$ onde a vontade de Deus que valoriza e comunica a vida ao homem deve ser cumprida de maneira ilimitada. ${ }^{143}$

O Messias da Sabedoria propôs uma paz que superasse não somente o ato violento, mas também sua retribuição pela mesma violência. O mal e sua sugestiva e consequente retribuição são anulados, assim como o circulo vicioso da violência contra a violência. Jesus conscientiza o ser humano sobre a importância de sua autonomia de resistência à violência e à contraviolência. Esta última exerce

\footnotetext{
${ }^{140}$ Cf. MOLTMANN, Jürgen. O Deus crucificado. p. 184.

${ }^{141}$ SCHILLEBEECKX, Edward. Jesus. p. 154.

142 Cf. MOLTMANN, Jürgen. O caminho de Jesus Cristo: cristologia em dimensões messiânicas. São Paulo: Academia cristã, 2009, pp. 188-191.

${ }^{143}$ Cf. GOPPELT, Leonhard. Teologia do Novo Testamento. São Paulo: Teológica. 2002, p. 125.
} 
um papel de contínuo fator justificador e estabilizador do mal. Sem esta resistência, o mal é conduzido ao absurdo. ${ }^{144}$

Por isso Jürgen Moltmann declara:

Agir sem violência é o agir que liberta da violência. A esse agir Jesus denomina amor aos inimigos. Aqui o traduzimos por responsabilidade pelos inimigos. De acordo com o Sermão do Monte, o amor ao inimigo é a forma perfeita do amor ao próximo como Deus deseja, é o caminho para uma paz duradoura na terra. Quem quer que se envolva numa desavença - pessoalmente ou coletivamente - e se meta num conflito, este se submete a lei da reciprocidade e retribuição. ${ }^{145}$

Segundo o referido teólogo, o exercício desta retribuição conduz a um fatal circulo vicioso, tornando a vítima, inimigo de seu inimigo, numa crescente espiral de ameaça mútua, erroneamente alimentado por justificativas ilusórias. O Sermão do Monte é um componente norteador oriundo do universo ético do Reino de paz e graça do Deus que faz nascer o seu sol sobre maus e bons, justos e injustos, provendo manutenção de vida a todos. A sabedoria do Criador rompe com os limites de fixação sobre o inimigo e a consequente necessidade retributiva ao mal sofrido. ${ }^{146}$ Portanto, Jesus anunciou o Deus que se apieda livre e graciosamente em amor antecipatório ao ser humano, independente de seu cumprimento fiel ou não dos preceitos da Lei mosaica.

Maria Clara Bingemer descreve assim o cerne existencial da lei para Jesus:

A liberdade de Jesus diante da Lei contém para nós um ensino fundamental: o bem do outro, o bem do semelhante, passa na frente de toda a lei positiva. De tal maneira que esse bem do ser humano tem de ser a medida da liberdade humana. Jesus aceita a lei e a respeita, desde que ela contribua para que o povo seja mais feliz, tenha mais justiça, seja mais fiel a Deus e mais justo com os seus semelhantes. ${ }^{147}$

Através de seu chamado ao discipulado, seu aprofundamento hermenêutico existencial do sábado e suas antíteses postuladas no sermão do monte, fez-se configurada de forma límpida, a imagem do Deus livre, soberano em sua graça. Logo, toda a separação legalista entre piedoso e pecaminoso é transcendida, pois de forma nova e tridimensional ele aprofunda a compreensão da lei, até então

\footnotetext{
144 Cf. MOLTMANN, Jürgen. O caminho de Jesus Cristo. p. 203.

145 Ibid., p. 206.

${ }^{146}$ Cf. Ibid., p. 206.

147 BINGEMER, Maria Clara Lucchetti. Jesus Cristo: servo de Deus e Messias glorioso. São Paulo: Paulinas; Valencia, ESP. Siquem, 2008, p. 34.
} 
muito limitada e aprisionada por seus obsessivos defensores. ${ }^{148}$ Portanto, Ele os leva ao fundo, ao oceano da livre e perdoadora graça de Deus e eles asfixiam sem fôlego ante a profundidade de seu mistério escatológico.

Além de esvaziar e aprofundar conceitos sobre a lei e a tradição, a aparição de Jesus desfigurou acentuadamente compreensões e expectativas ante os vaticínios apregoados pela demanda apocalíptica e os antigos profetas. O Messias está entre o povo, seu Reino floresce entre pecadores e publicanos e não anuncia julgamento, mas as boas novas da justificação graciosa, e isso confunde, humilha e desaloja. A descida é acentuada. ${ }^{149}$

Jürgen Moltmann distingue o anúncio do Reino por Jesus do de João por seu conteúdo:

Ele anunciava literalmente a mesma coisa que João: “o Reino de Deus está próximo”, mas, em relação ao conteúdo, ele anunciava esse Reino de maneira diferente. O Reino não vem como julgamento, de modo que seja preciso antecipálo em si mesmo por meio de arrependimento para entrar nele. Antes, ele vem antecipado por meio da palavra do evangelho de Jesus, por meio de sua entrega aos pobres, pecadores e publicanos, como graça livre incondicional, que procura 0 perdido, e aceita os sem lei e injustos. E essa outra justiça de Deus, que Jesus promete e demonstra, foi o que o separou de João Batista e seu movimento de penitência. ${ }^{150}$

Jesus acolhe aos sem lei e transgressores mediante essa justiça de Deus, contradizendo assim, todas as tradições do seu povo. Seu messianismo não encontra respaldo em nenhuma tradição de Israel, rabínica ou farisaica, profética

\footnotetext{
${ }^{148}$ Cf. MOLTMANN, Jürgen. O Deus crucificado. p. 167. O rabinismo farisaico concedia à Halaká a mesma autoridade que a própria Torá. Essa igualdade era fundamentada historicamente apresentando-se a Halaká como uma tradição oral secreta proveniente de Moisés. Entretanto, Jesus aponta para a diferença fundamental existente entre a Torá e Halaká. É exatamente essa sua postura que gera o grande choque entre Ele e as autoridades religiosas de sua época. Independentemente da autenticidade de alguns elementos da tradição, Jesus se posicionou frente à Halaká da seguinte maneira: a) diferenciando claramente o mandamento veterotestamentário da Halaká dos escribas, divergindo da opinião geral vigente no ambiente judeu de sua época; b) rejeitou a Halaká como "mandamento humano" e "tradição de homens" por encontrar-se direcionada a favorecer corrompidas intenções humanas de limitar o mandamento humano e transgredi-lo; c) Mesmo sabendo que os essênios criticavam a Halaká oficial do rabinismo farisaico opondo-se à mesma por uma interpretação radical, e rejeitando terminantemente a Halaká, Jesus não discutiu a respeito da interpretação da lei com seu ambiente, conforme a oposição essênia que adotava uma interpretação própria frente à leitura farisaica, mas Ele modifica a relação do homem diante da própria Lei. Se a visão judaica da Lei conduzia toda situação pela casuística, Jesus por sua vez, a excluía. Cf. GOPPELT, Leonhard. Teologia do Novo Testamento. pp. 119-121.

${ }_{149}$ Cf. MOLTMANN, Jürgen. Op.cit., p. 168.

${ }^{150}$ Ibid., p. 169.
} 
ou apocalíptica, onde a consumação da justiça consiste no trunfo final da lei. Jesus está sozinho, apenas amparado por Aquele que ele chama de “meu Pai”. 151

\section{2. \\ O caminho da inclusão}

O desprezo que alguns judeus da seita dos fariseus tinham por outras pessoas consideradas impuras é fundamental para que se compreenda o caráter socio-agregador do Reino de Deus proclamado por Jesus.

A inclusão de pessoas designadas pecadoras por sua má conduta, prostitutas e assaltantes, entre tantas outras, bem como daquelas que se ocupavam de profissões consideradas desprezíveis, como cobradores de impostos, açougueiros e pastores, afrontou ousadamente a moral religiosa vigente nos dias em que Jesus esteve em nosso meio. Desprezados e marginalizados, estes, não podendo confiar em suas próprias obras ante as prescrições da lei, ansiavam que a misericórdia divina lhes proporcionasse uma nova perspectiva de salvação. ${ }^{152}$

Entretanto, a presença de Jesus, sua convivência e comensalidade com pecadores e impuros, é oferta de comunhão salutar. Os leprosos, doentes tão marginalizados que sequer podiam relacionar-se com algum outro ser humano, sendo condenados ao isolamento total, passando noites ao relento e sem direito a remissão, foram por ele restaurados de sua lepra e de sua solidão social. ${ }^{153}$

Por ocasião do banquete oferecido pelo fariseu a Jesus em sua casa, e para escândalo daquele homem religioso, ele comungou com uma mulher conhecida como pecadora, acolhendo sua afetiva unção, respaldando assim sua atitude mediante a ilustração de uma parábola que sublinha a coerente gratidão de quem tem uma grande dívida perdoada (Lc 7,36-50). É a comunhão proporcionada pelo perdão mediante a fé. Os mais carentes são os mais gratuitamente apaixonados, e a eles é concedida a comunhão libertadora. Assim, o Reino de Deus apregoado por Jesus os absolve e integra. ${ }^{154}$

Verdadeiros sentinelas da Galiléia quanto à guarda de prescrições de pureza legal e contato com pecadores, também os escribas objetaram sobre a refeição compartilhada entre Jesus e os publicanos na casa de Levi, filho de Alfeu

\footnotetext{
${ }^{151}$ Cf. Ibid., p. 169.

${ }^{152}$ Cf. RUBIO, Alfonso Garcia. O encontro com Jesus Cristo vivo. p. 43.

${ }^{153}$ Cf. BINGEMER, Maria Clara. Jesus Cristo. p. 43.

${ }^{154}$ Cf. SCHILLEBEECKX, Edward. Jesus. pp. 199-200.
} 
(Mc 2,15-17). ${ }^{155}$ Como relembra Wilson de Souza, havia motivos políticos e econômicos que justificavam uma objeção natural à aberta postura afetiva de Jesus:

A tão celebrada Pax Romana era a tirania da potência de ocupação que ameaçava esmagar o povo pela arrogância arbitrária, pela corrupção descarada e brutais injustiças. As impenitências fiscais do ocupante pesavam duramente sobre a população; onze diferentes impostos, tributos e taxas cobrava o patrão inclemente por intermédio dos seus agentes judaicos, os famigerados publicanos. Não admira que o povo odiasse profundamente estes simpatizantes colaboradores de Roma e os considerasse traidores. ${ }^{156}$

Esta acentuada segregação social é percebida também pela comum utilização de termos relacionados do tipo “fortes-doentes" e "fariseus-publicanos" no universo conceitual e antagônico de justos e pecadores. Portanto, ao buscar a companhia desses pecadores e publicanos Jesus se viu num conflito gerado pelo grande abismo existente entre justos e injustos e bons e maus, imposto não somente por questões de justiça, mas por um forte legalismo socio-religioso. ${ }^{157}$

O sistema de valores que funcionava como fundamento daquela sociedade fazendo distinção entre bons e maus era abstrato, pois não se levava em conta as dificuldades de determinadas classes de pessoas em cumprir a lei por questões sociais. Desprezava-se não somente os pecadores ou impuros, mas também e principalmente as mais sérias questões econômicas que alimentavam a miséria da prostituição nesta época. Tanto na situação de publicanos, prostitutas e outras classes de pessoas marginalizadas, nunca se indagou a causa de seu não comparecimento aos ditames religiosos vigentes ${ }^{158}$. Jesus nunca justificou o pecado, a corrupção ou a prostituição, mas desejou o banimento, a extinção daquele circulo vicioso discriminatório tão predominante ao sistema de valores dos “justos” de sua época. Por isso ele foi taxado como desclassificado. ${ }^{159}$

Na verdade, sua figura humana desprovida de qualquer correspondência a iminente expectativa por libertação, era a própria contradição e desqualificação do padrão messiânico em pessoa, como descreve Jürgen Moltmann:

\footnotetext{
${ }^{155}$ Cf. Ibid., p. 203.

${ }^{156}$ LOPES, Wilson de Souza. Aos pés de Jesus: O sermão do monte para o $3^{\circ}$ milênio. São Paulo: Cultura cristã, 2001, p. 145. Cf. também LAPIDE, Pinchas. O sermão da montanha: utopia ou programa? Rio de Janeiro: Petrópolis, Vozes, 1986, p. 91.

${ }^{157}$ Cf. MOLTMANN, Jürgen. O caminho de Jesus Cristo. p. 179.

${ }^{158}$ Cf. Ibid., p. 180.

${ }^{159}$ Cf. Ibid., p. 181.
} 
O que causa a contradição é que ele, como homem sem poder, antecipa o poder de Deus como graça aos rejeitados e indefesos. Vinculado a sua baixeza, sua anunciação estava aberta a sua rejeição. Vinculada a sua pretensão de poder, sua humanidade era refutável por meio de sua rejeição e morte. A contradição inerente entre sua pretensão e sua pobreza impregna totalmente a sua manifestação. ${ }^{160}$

Contudo, todo esse imagético paradoxo de pobreza, baixeza e abandono traduz de forma eficaz a franca abertura do reino de Deus em justiça e graça aos excluídos. $^{161}$

Por ocasião do episodio conhecido como "lava-pés”, ante a iminência de sua morte, Jesus assumiu plenamente sua missão como servidor da comunidade do povo de Deus. Mais do que um ato de modéstia ou humildade, ele afirmou uma igualdade de camadas diante da estratificação vigente, e por conseguinte, o serviço e a responsabilidade mútuas em fraternidade, a amizade de um mesmo destino rumo a uma mesma missão de inclusão proposta pelo Reino. ${ }^{162}$ Sua preocupação transcendia a inclusão dos justos, requerendo ainda a não exclusão dos injustos, assinalando assim a importância de sua presença à mesa de Deus e à convivência social, resgatando-os, portanto, de seu isolamento. ${ }^{163}$

A comensalidade de Jesus e seus discípulos com pecadores e pessoas de má reputação tem profundo significado, pois de acordo com a mentalidade judaica da época, comer com alguém significava solidarizar-se com tal pessoa. Mas do que comunhão de mesa significava a comunhão de vida, por isso muitos se escandalizavam dele por sua atitude. ${ }^{164}$ A esta comensalidade é dado um profundo sentido messiânico, como explica Jürgen Moltmann:

A comunhão de mesa de Jesus com pecadores e publicanos adquire especial significado no horizonte de sua mensagem messiânica. Em si, toda comunhão de mesa cria comunhão humana. O reino de Deus, porém, que Jesus anuncia e demonstra com sua convivência com pobres, doentes, pecadores e publicanos, não apenas traz o domínio de Deus sobre sua criação, mas também a grande ceia de alegria dos povos [...]. ${ }^{165}$

\footnotetext{
${ }^{160}$ MOLTMANN, Jürgen. O Deus crucificado. pp. 170-171.

${ }^{161}$ Cf. Ibid., 171.

162 Cf. PICO, Juan Hernandez; SOBRINO, Jon. Solidários pelo Reino: os cristãos diante da América central. São Paulo: Loyola, 1992, pp. 23-24.

163 Cf. SCHILLEBEECKX, Edward. Jesus. p. 204.

${ }^{164}$ Cf. BINGEMER, Maria Clara. Jesus Cristo. p. 43.

${ }^{165}$ MOLTMANN, Jürgen. O caminho de Jesus Cristo. p. 182.
} 
Portanto, Jesus apresentou o reino de Deus como um grande banquete a ser celebrado ${ }^{166}$ e mais do que um socorro material, sua mensagem de vida apregoava a restauração da comunhão entre Deus e o ser humano. Por isso, a imagem mais significativa de sua boa nova relacional era a mesa, e seu ensino era a prática de uma comensalidade vaticinadora ao pleno banquete futuro com seu povo. Tudo isso prenuncia que ele comerá e beberá com os seus discípulos no Reino de Deus (Mc 14,25; Lc 22,30) e pessoas procedentes de todos os cantos da terra serão reunidas para se assentarem com os santos do Antigo Testamento (Mt 22,1-14; 25,1-12). Todas essas metáforas foram por ele utilizadas para descrever a restauração da comunhão entre Deus e os seres humanos. ${ }^{167}$

Ao analisar o caráter messiânico inclusivo do sermão da montanha, Moltmann distingue duas possibilidades teológicas relacionais entre o evangelho de Cristo e a Torá de Israel. A primeira por antítese, onde o evangelho é concebido como o fim da Lei e a segunda por cumprimento, quando o evangelho de Cristo interpreta messianicamente a Torá de Israel para todos os povos, a qual tem o seu cumprimento através do amor na irrupção do Reino de Deus. Segundo ele, o sermão do monte é na verdade a proclamação da Torá messiânica:

...assim como Moisés trouxe a Torá do monte de Deus para o povo de Israel, assim o Messias Jesus proclama, a partir do monte de Deus para o povo de Israel, a Torá messiânica "para os discípulos e para todo o povo"168

Este sermão é endereçado primeiramente ao povo pobre, oprimido e perdido, em multidões que se assentam a ouvir o mestre (Mt 5,1). A profundidade de seu conteúdo não consiste de doutrina elitizada, mas de um sábio e apocalíptico discurso popular dirigido a todos ouvintes. Ele será fecundado no coração do povo (ochlos) despertando e congregando os aflitos e sobrecarregados da terra, que comporão o novo Israel do tempo messiânico. Sua mensagem declara bem aventurados aos passivos de circunstâncias: pobres, tristes e sofredores, bem como aos que seguem Jesus em seu caminho messiânico: misericordiosos, carentes de justiça e perseguidos por causa dela, pacificadores e puros de coração. Trata-se de um sermão relacional, que proporciona um “etos” de comunhão, a comunhão messiânica de Cristo. Sua sabedoria é vivenciada publicamente. Seu sermão

\footnotetext{
${ }^{166}$ Cf. Ibid.

${ }^{167}$ Cf. LADD, George Eldon. Teologia do Novo Testamento. p. 70.

${ }^{168}$ MOLTMANN, Jürgen. O caminho de Jesus Cristo. pp. 193-194.
} 
esvazia a elitizada seletividade dogmática conclamando do meio do povo, com o povo e para o próprio povo pessoas que pratiquem a vontade messiânica do Pai, vivendo o etos de seu discipulado na comunhão de amor e serviço para com seus irmãos. Onde o conhecimento apenas não basta e as questões sociais clamam por vívida sabedoria, a demanda é relacional e a exclusão é excluída. ${ }^{169}$

\section{3. \\ O caminho da libertação de sistemas opressores}

Segundo Jürgen Moltmann, muitas vezes a tradição dogmática reduziu a atuação poderosa do Espírito Santo através de Jesus ao âmbito espiritual independente de qualquer abrangência política, distinguindo sua atuação messiânica nesse mundo pelo viés exclusivo de uma vivência espiritual. Por essa concepção o seu reino sempre estaria além desse mundo (Jo 18,36).

Entretanto, a ação criadora, salvífica e profética do Espírito de Deus durante toda a história da criação e sua presença permanente em Jesus demonstra o início da salvação escatológica humana, da nova criação e da revelação da glória de Deus. ${ }^{170} \mathrm{O}$ poder emanado pelo Reino de Deus faz irradiar a força da nova criação, que expulsa demônios, cura doentes e restabelece a criação fragmentada. ${ }^{171}$

Quando por ocasião de sua tentação no deserto, o diabo ofereceu a Jesus meios para a tomada messiânica do poder sobre Israel e sobre os povos. Sob condição estrita de sua adoração ele tentou propor um inadequado caminho de atalho às demandas sociais de sua época (Mt 4,1-11). ${ }^{172}$

Moltmann relaciona a rejeição de Jesus contra esse tipo de tomada de poder proposta pelo tentador, a um esvaziamento de possibilidades existenciais

\footnotetext{
${ }^{169}$ Cf. Ibid., p. 195.

${ }^{170}$ Cf. Ibid., pp. 151-152.

${ }^{171}$ Cf. DUNN, James D. G. Unidade e diversidade no Novo Testamento: um estudo das características dos primórdios do cristianismo. Santo André. Editora Academia Cristã: 2009, p.79. Os exegetas contemporâneos têm salientado a diferença entre os milagres do evangelho e as maravilhas ou exorcismos helenísticos e rabínicos. Mais do que maravilhas, os milagres do evangelho representam acima de tudo, signos escatológicos que requerem a fé. Assim, o Reino de Deus é a força de Deus para a salvação do ser humano (Rom 1,16), a qual se revela através de dois veículos: a palavra de Deus e os signos visíveis. Portanto, os milagres possuem uma função "sacramental", como sinais visíveis da salvação que acompanha a chegada dos tempos escatológicos. Os exorcismos sinalizam a chegada do Reino de Deus e a derrota de Satanás (Mt 12,28), enquanto a cura de doentes é um sinal da nova vida. Seus milagres são ações querigmáticas, pois eles têm a função de proclamar a presença real do Reino e de seu portador. TERRA, J. E. M. O Jesus Histórico e o Cristo querigmático. São Paulo: Loyola, 1977, p. 168.

${ }^{172}$ Cf. MOLTMANN, Jürgen. O caminho de Jesus Cristo. pp. 151-152.
} 
político-econômicas e religiosas experimentado por ele quando o Espírito o conduziu ao deserto:

...por meio das tentações, para as quais o leva esse mesmo Espírito, lhe são cortados os meios econômicos, políticos e religiosos para "tomada de poder”, sua paixão e impotência já está traçada antecipadamente: ele vence por meio de sofrer e morrer. Por ocasião de sua entrada triunfal em Jerusalém, ele não oferece pão ao povo, ao entrar no templo e ele não executa o sinal messiânico e diante do romano Pilatos não invoca as legiões celestiais para conquistar a vitória militar. Da história da tentação segue o caminho para cruz. ${ }^{173}$

Portanto, o episódio do deserto por si só proclama um despojamento sistemático do Filho de Deus. No despir de tais recursos, em sua fraqueza, é que agirá o Espírito.

Ao contrário de uma perspectiva utópica de um futuro distante, o evangelho já traz a irrupção do futuro pela palavra que liberta. Deus vem ao seu povo através do anúncio de seu Reino imediato, ilimitado, infindável, sinalizado por justiça, comunhão e liberdade. Seu alvo situado são os pobres, doentes e desesperançados. Sua mensagem é a própria autoridade da liberdade humana. ${ }^{174}$

Num mundo caótico e machucado, o evangelho anuncia o agir vivificador e recriador de Deus proporcionando uma nova ordem natural e realista de valores. A preocupação do Messias destrona a doutrina, tão venerada pelos fariseus e saduceus, aproximando-se da realidade dos “pobres”; um termo muitíssimo abrangente como explica Jürgen Moltmann:

O termo coletivo os pobres abrange os famintos, desempregados, doentes, desanimados e enlutados. É o povo subjugado, oprimido e humilhado (ochlos). Os pobres são doentes, aleijados e não-sedentários (Lc 14,21-23). São mendigos nas ruas e estradas (Mt 11,2-5). São os tristes (Lc 6,21). Sua situação exterior é descrita suficientemente: procura-se penhorar inclusive sua roupa interna (Mt 5,40). Respondem com seu próprio corpo (Lc 12,58) e com sua família (Mt 18,23-35). Com freqüência tem de entregar a si e suas famílias a escravidão e à prostituição, isto é, à total destituição dos direitos. Os pobres são as "nãopessoas”, os "sub-homens", os desumanizados, "material-humano". ${ }^{175}$

Portanto, onde quer que falte a dignidade humana, há pobreza e desumanização. A proposta de "pessoa" no reino de Deus em Jesus objetiva a transformação de qualquer indivíduo, rico ou pobre, em pessoa, como genuíno

\footnotetext{
${ }^{173}$ Ibid., p. 152.

${ }^{174}$ Cf. Ibid., pp. 156-157.

${ }^{175}$ Ibid., pp. 160-162.
} 
cidadão desse reino. ${ }^{176}$ Para tal, faz-se necessária uma conversão que venha abranger não somente a vida religiosa das pessoas, mas seu modo de vida pessoal e comunitário, e ainda, os próprios sistemas de vida onde esses modos encontramse ordenados. ${ }^{177}$

A conhecida Pax Romana constituiu um clássico e pernicioso sistema socio-político, ao qual se atribuiu méritos de uma nova ordem mundial de paz e segurança para a elite de Roma. Entretanto, para os povos conquistados, as principais marcas desse domínio romano foram a desordem e a devastação. Quem tentou resistir à tirania desse novo sistema foi massacrado e escravizado enquanto suas casas e aldeias eram destruídas. ${ }^{178}$

Richard Horsley descreve de forma suscinta esse drama social:

As exigências econômicas cada vez maiores, consequência das múltiplas camadas de governantes na Palestina, exarcebaram o impacto imperial sobre a ordem social. Os evangelhos revelam um povo sobrecarregado de dívidas e fome, atormentado pela paralisia física e social e em geral desesperado com as circunstâncias vividas... As próprias formas sociais da família e da comunidade aldeã desintegraram-se sob as pressões da ordem imperial romana. ${ }^{179}$

Jesus, porém, confiava que a referida ordem romana já se encontrava na pauta de julgamento do Reino de Deus, e inicia uma missão de restauração social entre os povos subjugados. Respaldado pela condenação de Deus a toda aquela ordem romana composta por governantes romanos, subalternos herodianos e sacerdotes, Ele procurou sanar os efeitos do império, reconstruindo no povo oprimido a vida em comunidade. Assim, ele buscou restabelecer de forma justa, relacionamentos comunitários pautados em igualdade social e econômica mútua. $^{180}$

Os evangelhos mostram um Jesus que se relaciona com pessoas inseridas em contextos difíceis. Em ato de solidariedade, por diversas vezes doentes e oprimidos foram conduzidos até Jesus, ou o próprio Jesus foi conduzido a eles por parentes e amigos. Ele os restaurou por instrumentalidade da solidariedade. ${ }^{181}$

\footnotetext{
${ }^{176}$ Cf. Ibid.

${ }^{177}$ Cf. Ibid., pp. 165-166.

${ }^{178}$ Cf. HORSLEY, Richard. Jesus e o império: o Reino de Deus e a nova desordem mundial. São Paulo: Paulus, 2004, p. 111.

${ }^{179}$ Ibid., p. 112.

${ }^{180}$ Cf. Ibid., p. 111.

${ }^{181}$ Cf. Ibid., p. 114.
} 
Assim, o Reino de Deus manifestou-se através da libertação da hemorragia (Mc 5,34), da cegueira (Mc 10,52) e até mesmo da própria morte (Mc 5,23). Tais operações foram reivindicadas como evidências da presença da salvação messiânica pelo próprio Jesus (Mt 11,4-5), como sinais de que seu Reino culminará um dia na imortalidade do corpo. Sua preocupação, portanto, consistia não somente com as almas das pessoas, mas com uma salvação integral das mesmas. Ele via o ser humano em sua totalidade. ${ }^{182}$

Quando expulsa espíritos impuros, Ele os desapossa e arruína (Mc 1,2326), libertando a pessoa de uma força “estrangeira” de ocupação, pois numa condição social e espiritual mais geral, pessoas também, de certa forma, se encontravam sob o ataque de uma força sobre-humana destrutiva que guerreava contra Deus pelo controle da sociedade e da história. Por ocasião de sua libertação pelo Cristo, são resgatadas de um estado de existência anti-social e de violento auto-flagelo a um estado normal de saúde mental e de vida social (Mc 5,2-20). ${ }^{183}$ Na verdade, suas curas efetuadas não eram motivadas apenas por um simples ato de misericórdia, mas integravam também um programa de saúde partindo da pessoa para a sociedade, da saúde pessoal para a cura do corpo social. ${ }^{184}$

Quando Jesus é indagado sobre sua messianidade pelos discípulos de João, comparece a referida questão relacionando seu ministério ao cumprimento de antigos anseios israelitas, quando declara que os cegos recuperam a visão, os coxos andam e aos pobres é anunciada a boa nova (Mt 11,5). Sua mensagem ao povo desalentado que chora e definha sob a tirania estrangeira é sempre de esperança.

Ante a desintegração social ocorrente na Síria-Palestina, Jesus visava fortalecer a família e a solidariedade social. Jesus recrimina os escribas e fariseus por sua atitude desonrosa e legalista, quando incentivam camponeses a sustentarem o templo com ofertas que deviam antes, ser utilizadas por esses para provisões de suas famílias, seus pais necessitados (Mc 7,1-13). Assim, eles não cumpriam o mandamento básico da aliança que mandava honrar os pais. Ele reafirmou a importância dos laços matrimoniais na formação social fundamental

\footnotetext{
${ }^{182}$ Cf. LADD, George Eldon. Teologia do Novo Testamento. p. 72.

${ }^{183}$ Cf. HORSLEY, Richard. Jesus e o império. p. 113.

${ }^{184}$ Cf. Ibid., p. 114.
} 
da família quando questionado sobre o divórcio. Dada a desintegração de algumas famílias, Ele desejava fortalecê-las como unidade social. ${ }^{185}$

O sistema teocrático, por sua vez, combina poder político e poder religioso que se respaldam mutuamente. Essa combinação explosiva fomentou nos líderes religiosos da época de Jesus uma sede por poder maquiada por pretensas exigências piedosas de radical religiosidade. Enquanto Jesus manifesta de forma concreta o amor e a misericórdia de Deus aos marginalizados, os sacerdotes vivem uma vida mecânica e vazia mergulhada num frio ritualismo religioso. E isso justificará um constante embate entre Jesus e eles.

A surpreendente e marcante peculiaridade dos sumos sacerdotes consiste de sua constante articulação com o sofrimento e a morte. Como sobrecarregaram ao povo, assim também o farão a Jesus, até a sua morte de cruz. Sua liberdade, munida pelo poder de fogo da denúncia, não tolerará o jugo religioso dessa pesada opressão institucional. Dominação e opressão não podem ser toleradas pelo verdadeiro Messias de Deus. Assim, ele os desclassifica como modelo, através de seu excelente e humilde exemplo de serviço despojado aos oprimidos. O maior sem dúvida é aquele que serve a todos (Mc 10,42).

A figura do Deus de Israel havia sido transformada em um pesado ídolo cultuado pelos líderes religiosos e carregado por pessoas humildes que cambaleavam ao peso de toda aquela triste religiosidade estéril. Assim, Jesus prenuncia um golpe fatal no coração de toda a falsa religião de sua época: o templo e sua cidade santa (Mt 24,1-2).

Consciente do perigo que corria, Jesus afunila seu destino ao dirigir-se a Jerusalém, sede das principais autoridades gestoras ao referido sistema, onde expulsa os vendilhões do templo e expõe a podridão dos "sepulcros caiados" e o veneno das mais peçonhentas “víboras” (Mt 23,27 e 33).

Longe de qualquer inconsequência e com a devida intransigência, Ele não somente lutou pela liberdade, mas pela essência de sua soberania ante as demandas e implicações de sua postura libertadora durante a vida e até a sua morte. Sua vida e morte materializaram um Kerygma de livre autenticidade.

Jesus valorizou a vida mediante o exercício da liberdade que põe acima de tudo o bem do outro. A liberdade que se realiza por vias de alteridade, tendo Deus

${ }^{185}$ Cf. Ibid., p.116. 
como seu absoluto e o seu semelhante como o mais caro investimento relacional, acima de toda instituição religiosa, pois a verdadeira experiência de vida com Deus humaniza aquele que a busca. ${ }^{186}$

Assim, o Criador se compadece de sua criação, libertando-a, e restabelecendo a normalidade aos oprimidos, por intermédio dos poderes do mundo futuro, pela força do domínio do seu Reino. ${ }^{187}$

\section{4. O caminho da livre doação amorosa}

A teologia da paixão divina fundamenta-se na expressão chave da Escritura: “Deus é amor” (I João 4,16). O amor difere das paixões perturbadoras, justamente por sua apaixonada capacidade de auto-comunicar o bem. O amor é engajamento, é saída de si, é alteridade, entrega ao outro. O amor é via aberta de passagem à vida. Aquele que ama desprende-se de si ao outro sem aniquilar a sua identidade. $^{188}$

Deus não somente ama, mas pessoalmente Ele é amor e seu amor revela ao mundo sua auto-distinção e auto-identificação. O Deus que ama o mundo é aquele que se relaciona revelando sua distinta divindade ao objeto do seu amor (João 3, 16).

Sua auto-diferenciação e auto-identificação manifestam-se neste amor que o caracteriza por toda a eternidade, algo que perdura em sua essência, traduzindo também em si um processo de sofrimento pelo que é negativo. A mesma intensidade que o identifica e distingue por toda a eternidade assinala a sua autenticidade e força de contraste presente em toda sua auto-comunicação. Quanto mais profunda e autenticamente distinta é a sua essência em amor, mais desprendida é a sua revelação relacional para com o mundo amado. ${ }^{189}$

Ao decidir-se por sua auto-comunicação, Deus abre o íntimo de sua essência, comunicando o verdadeiro Bem que é Ele mesmo em seu ser no mundo. Ele compartilha seu amor por um prazer profundo e eterno. ${ }^{190}$

\footnotetext{
${ }^{186}$ Cf. BINGEMER, Maria Clara. Jesus Cristo. pp. 38-41.

${ }^{187}$ Cf. MOLTMANN, Jürgen. O caminho de Jesus Cristo. pp. 169-171.

188 Cf. MOLTMANN, Jürgen. Trindade e Reino de Deus: uma contribuição para teologia. Petrópolis, Rio de Janeiro: Vozes. 2011, p. 70.

${ }^{189}$ Cf. Ibid., p. 71.

${ }^{190}$ Cf. Ibid., p. 72.
} 
Sem nenhuma espécie de coação, mas exclusivamente por seu amor, Deus fez existir algo diferente de si mesmo. Toda a criação revela além de sua bondade, sua soberania. Ele criou por absoluta liberdade, demonstrando assim um invencível desejo de compartilhar de si. Para tal, sai de si e vence o isolamento tornando o ser humano participante de sua glória (Ef. 1,3-14). Trata-se da mais plena realização a ser experimentada pelo ser humano. ${ }^{191}$

A Criação do mundo e do ser humano encontra correspondência no amor e alegria do Deus que cria, não somente porque pode, mas porque desejosamente tenciona criar.

Se trinitariamente o Pai ama o seu Filho unigênito desde toda a eternidade com um amor essencialmente necessário que concebe e gera, o Filho, também pela mesma necessidade essencial, corresponde ao amor de seu Pai mediante sua obediência e devoção. Trata-se de um íntimo amor por um igual correspondente, um ser da mesma natureza, um amor necessário, não livre.

Entretanto, na medida em que esse amor se expande para fora de si, deixa de ser simplesmente o amor que concebe e gera para tornar-se também um amor criador não essencialmente necessário, porém livre. Um amor livremente doado. Sua correspondência se dará em outro plano de existência conforme descrito por Jürgen Moltmann:

\begin{abstract}
Quando esse amor livre e criador encontra correspondência por parte do homem, que em virtude dele foi chamado à existência, então esse amor encontra o seu eco, sua resposta, sua própria imagem e com isso sua felicidade na liberdade e no outro. Deus é amor, o que significa que Ele é amor gerador e criador. Ele se comparte com o seu igual e também com o seu outro. Deus é amor, isto é, Ele é o amor que corresponde essencial e livremente. O amor, pelo qual Deus ama o mundo, de modo criador e padecente, não é outro do que o amor com que com Ele se identifica, desde toda a eternidade. Inversamente, o amor criador e padecente, está desde sempre implícito na essência eterna do seu amor. ${ }^{192}$
\end{abstract}

Quando Deus cria, Ele comparte o seu eterno amor com o outro, como uma extensão, um seguimento da eterna história de amor entre o Pai e o Filho. Assim, inicia-se o autorrebaixamento e a auto-humilhação de Deus, o sofrimento de seu amor eterno. Deus não atua somente para fora, mas também para dentro, onde Ele abre espaço para sua existência tomando tempo por causa dela e

${ }^{191}$ Cf. BASTOS, Levy da Costa. Os caminhos da salvação. São Paulo: Fonte Editorial, 2007, p. 15.

${ }^{192}$ MOLTMANN, Jürgen. Trindade e Reino de Deus. p. 72. 
concedendo tempo a ela, proporcionando-lhe a liberdade e conservando-lhe a mesma. Sua auto-limitação e recuo demonstra o sofrimento do seu amor criador. Sua liberdade criadora sempre constitui um sofrimento, um despojamento. Por isso, seu amor criador e redentor sempre se manifesta por meio da dor e padecimento. ${ }^{193}$ Deus se retrai em consideração à autonomia de sua criação. Sua presença envolve enquanto dá às suas criaturas consistência própria. Face a sua própria singularidade, Ele, em alteridade, põe em diálogo histórico-salvífico diante de si o irredutivelmente diferente, objetivando o encontro e a comunhão com suas criaturas. A própria liberdade concedida a sua criação pressupõe o amor, que sempre se manifesta livre e espontaneamente, já que não se pode constranger alguém ao amor. Assim, quando Deus decidiu criar, desejou suas criaturas, quis se relacionar com essas livremente e dessa relação recíproca emergem alteridades e singularidades. ${ }^{194}$

Muito mais do que uma dependência paralisante, nossa criação estabeleceu uma expectativa de resposta livre, lúcida e madura. Aí é onde o ser humano deve comparecer aos amorosos apelos relacionais divinos também em amor. Do futuro ele atrai a história e o cosmos para a consumação plenificadora da trama amorosa com suas criaturas. ${ }^{195}$

Deus doa-se "no princípio", sendo a criação a primeira expressão do seu amor. Este sublime e fecundo sentimento materializou-se em Jesus, Palavra decisiva de Deus feita "carne”, que manifestou a mais profunda verdade sobre a autocomunicação de Deus. O Deus doador da vida encontra a superação em Jesus, através de quem torna-se mais do que Criador da vida, pois agora Ele também comunica ao homem a sua própria vida. ${ }^{196}$ Portanto, Jesus é a revelação de Deus, a chave hermenêutica da realidade que age de forma salvadora e criadora revelando o amor do Deus que solicita a abertura do ser humano a sua entrega amorosa. $^{197}$

Como explica Jürgen Moltmann, esse amor realiza-se em felicidade mediante uma livre correspondência:

\footnotetext{
${ }^{193}$ Cf. Ibid., p. 73.

${ }^{194}$ Cf. TAVARES, Sinvaldo S. Teologia da criação: outro olhar: novas possibilidades. Petrópolis, Rio de Janeiro. Vozes, 2010, p. 81.

${ }^{195}$ Cf. Ibid., p. 82.

${ }^{196}$ Cf. MATEOS, Juan. A utopia de Jesus. São Paulo. Paulus, 1994, p. 148.

${ }^{197}$ Cf. RUBIO, Alfonso Garcia. Unidade na Pluralidade: O ser humano à luz da fé e da reflexão cristãs. São Paulo: Paulus, 2001, p. 194.
} 
O amor que se comunica só passa a ser amor feliz quando houver correspondência no amor. Por isso, o Pai, na eterna correspondência do amor do seu Filho, é feliz. E se Ele compartilha o seu amor pelo Filho com aquele seu outro criado, então quer ser feliz também pela correspondência desse amor. Mas essa correspondência do amor é sempre uma resposta livre. ${ }^{198}$

Contudo, se o ser humano interpreta sua liberdade como ocasião para uma emancipação ou separação do Criador e suas criaturas, ele dá lugar ao pecado por seu individualismo e fechamento. Ele não constitui a razão de si próprio e nem deve viver exclusivamente em torno de seus interesses, pois foi destinado à comunhão com o Criador e sua criação. Essa atitude o faz afundar no mar de seu egoísmo. Por isso, o Filho unigênito de Deus desce despojadamente ao mais profundo oceano do interior humano para resgatá-lo desse arriscado abismo. Em amor e alteridade ele parte radicalmente em busca do diferente, o ser humano desfigurado, vítima de decisões erradas que por vezes lhe afastam do propósito existencial divino para sua vida e lhe cegam a visão periférica de todos os semelhantes e as demais criaturas ao seu redor. No mistério da encarnação, o próprio Deus se apaixona de forma livre, solidária e redentora em seu Filho, pelo ser humano envolvido pela ilusão e solidão de seu pecado. Sua sedução amorosa os atrai e liberta da solidão do pecado. ${ }^{199}$

Jürgen Moltmann descreve com propriedade as implicações solidarias da encarnação do Filho de Deus:

Na encarnação do Filho, o Deus uno e trino assume a situação limitada e finita. Ele não apenas se introduz nessa condição humana, mas aceita-a, e permite que ela participe da sua vida eterna. Ele se torna um Deus humano...Deus não assume apenas a finitude humana, mas também a condição do seu pecado e do seu abandono por Deus. Ele não apenas ingressa nessa situação, mas assume-a e faz dela uma parte do seu próprio e eterno amor... Deus passa a ser o Deus solidário até a morte e ainda muito mais. A encarnação do Filho não é uma passagem; ela é permanente na eternidade. Não há outro Deus a não ser o Deus encarnado, humano, solidário. ${ }^{200}$

A solidariedade divina no Filho viabiliza o encontro e restaura no ser humano a dignidade de filho de Deus, irmão de Jesus e casa do Espírito Santo. Em Jesus Cristo, Deus esvazia-se negando a si mesmo de forma cabal, seu

\footnotetext{
${ }^{198}$ MOLTMANN, Jürgen. Trindade e Reino de Deus. p. 128.

${ }^{199}$ Cf. TAVARES, Sinvaldo S. Teologia da criação. pp. 83 -84.

${ }^{200}$ MOLTMANN, Jürgen. Op. cit., p. 129.
} 
desígnio amoroso supera todo e qualquer obstáculo à reconciliação dos seres humanos consigo. $^{201}$

A peculiar maneira de agir do Espírito Santo o distingue, pois no diverso de si próprio é que confirma sua identidade. Sua presença sempre distingue sua singularidade. Ele trabalha na discrição e interioridade do ser humano, no misterioso fluir e contínuo fluir da história e nos mínimos particulares do cosmos realizando sua processual e perseverante obra de santificação. No seio da Trindade sua distinta presença propicia a mais excelente relação de paternidade e filiação entre o Pai e o Filho. Em seu escondimento, Ele cria condições para que Pai e Filho se realizem em perfeita reciprocidade e singularidade. Na reciprocidade do amor entre pai e Filho, Ele se faz presente. Assim também o Espírito, no interior de cada criatura, no desenrolar da história e nos meandros do cosmos otimiza modos, singularidades e alteridades inter-relacionais. Sua retração potencializa a fecundação de sua presença, que proporciona acolhimento, doçura e cuidado, proporcionando o tão almejado encontro e comunhão de Deus com suas criaturas e sua kenosis caracteriza, mais do que a discrição de sua ação, sua peculiar distintividade do Pai e do Filho, seu modo de ser. ${ }^{202}$

O amor doador divino também é a motriz do desafio que Jesus propõe aos seus discípulos: a busca pelo amor sem limites, como Deus ama. Um amor não utilitarista e nem pragmático, de entrega integral, despojado de todo motivo periférico, para alcançar em Cristo a semelhança divina (Fl 3,8). ${ }^{203}$

Juntamente ao amor a Deus, Jesus inclui o amor ao próximo em mais alto e sintético grau de importância frente a todos os outros mandamentos, objetivando assim uma transformação profunda no que diz respeito à importância do outro em nosso relacionamento com Deus. Com isso, o direito do outro também é um fim absoluto, uma vez que também lhe devemos um amor incondicional, pois como o Pai o amou, Jesus também nos ama (Jo 15,9), e como Ele próprio nos ensina, devemos amar uns aos outros como Ele nos amou (Jo 15,12). Logo, o amor a Deus e ao próximo são verdades essencialmente inseparáveis na vida da humanidade. ${ }^{204}$

\footnotetext{
${ }^{201}$ Cf. TAVARES, Sinvaldo S. Teologia da criação. p. 85.

${ }^{202}$ Cf. Ibid., pp. 86-87.

${ }^{203}$ Cf. BINGEMER, Maria Clara. Um rosto para Deus? São Paulo: Paulus, 2005, p. 62.

${ }^{204}$ Cf. MOINGT, Joseph. O homem que vinha de Deus. São Paulo: Loyola, 2008, p. 412.
} 
Mais do que uma obrigação, Ele lhes apresenta um ministério do amor, um êxodo de si ao próximo em generosidade profunda e divinamente misteriosa. $^{205}$

Maria Clara Bingemer ressalta a força de expressão do termo grego utilizado para nomear o amor de Deus:

\begin{abstract}
O termo usado para nomear esse amor de Deus é ágape, usualmente traduzida por amor...No amor/ágape, destacam-se a generosidade desinteressada e oblativa sem outro interesse ou possibilidade de gozo ou satisfação que não seja seu próprio exercício - e a disponibilidade para uma saída de si em direção ao outro. A não-profanável alteridade é o ponto de partida dessa doação de si, que tem sua raiz num Deus doador que é Ele mesmo seu próprio dom. ${ }^{206}$
\end{abstract}

A incondicionalidade característica desse amor proposta aos discípulos e aos seres humanos em geral, encontra seu modelo ético existencial no próprio Deus que ama a criação e a humanidade de forma ilimitada. Por isso, devemos nos amar porque ele nos amou primeiro (1 Jo 4,19), sem restrições ou condições.

Do encontro com Deus em Jesus Cristo surge uma experiência radical de existência que fundamenta responsavelmente toda liberdade e limite pessoais. ${ }^{207}$ O divino amor sofredor obterá sua feliz consumação através do encontro, libertação e comunhão eterna daqueles aos quais se dedica apaixonadamente em doação altruísta. Ele sofre com o amado e regozija-se na consumação de sua felicidade. $^{208}$

\title{
3.5. \\ O caminho da Vulnerabilidade
}

A presença de Deus, por si só, sempre descreveu um misterioso e apaixonado paradoxo existencial. Ao mesmo tempo em que Ele habita no céu, ele desce à sarça, à arca da aliança e ao templo, manifestando sua presença de forma despojada e engajada. ${ }^{209}$ O Deus descrito por ocasião do episódio do Êxodo é ao mesmo tempo, vulnerável à opressão do seu povo e intolerante ao seu sofrimento. Ele não abandona seu povo em meio à aflição, pelo contrário, misericordiosamente Ele escuta o clamor provocado pelos vergões das feridas do seu povo sob o jugo egípcio e conhecendo seus sofrimentos não lhe basta apenas a

\footnotetext{
${ }^{205}$ Cf. BINGEMER, Maria Clara. Um rosto para Deus? p. 62

${ }^{206}$ Ibid., pp. 63-64.

${ }^{207}$ Cf. Ibid.

${ }^{208}$ Cf. MOLTMANN, Jürgen. Trindade e Reino de Deus. p. 73

${ }^{209}$ Cf. MOLTMANN, Jürgen. O Deus crucificado. p. 347.
} 
compaixão própria, mas busca um envolvimento humano através do chamado do seu servo Moisés. ${ }^{210}$ Ele diligentemente participa da história de seu povo indo à sua frente como coluna de fogo e levando-o em seus ombros rumo à tão esperada terra que lhes prometeu. ${ }^{211}$ Ainda que elevado, Ele também habita com os de espírito humilde e contrito, estabelecendo uma relação essencial entre o Deus das vítimas e as vítimas que o buscam. Por isso, Ele apadrinha as viúvas e os órfãos (Sl 68,6), seu Reino é dos pobres, pois Ele se esvazia no frágil, e o frágil é por Ele assumido. ${ }^{212}$ Nos escritos proféticos percebe-se claramente que sua prioridade são aqueles que se encontram em pior situação, os mais debilitados, oprimidos e injustiçados na sociedade em que vivem. Estes são a sua primordial preocupação e Ele procura desacomodar a todos os que se fizeram indiferentes ao seu sofrimento. Esse Deus ama maternalmente com entranhas de misericórdia, a mesma misericórdia que requer ao invés de sacrifícios. ${ }^{213}$

No exílio de seu povo, lá está ele. Por isso, Ele sofre com seu povo, vai à prisão e sente a dor e a condenação de seus mártires. Quando seu povo é liberto, sua presença sai com eles. Pois sua shekinah compartilha o sofrimento e a redenção do seu povo. Sua presença não acompanha apenas a criatura limitada, mas também a culpada e sofredora, onde sua presença se completa. ${ }^{214}$

Em Jesus, Deus deu a conhecer ao mundo a vulnerável ortopraxia proposta pelo seu Reino, quando Jesus, a "parábola viva”, materializou a essência de sua doutrina curando, libertando e reabilitando excluídos e necessitados. É pela causa do oprimido que a glória do Reino de Deus é revelada. ${ }^{215}$

$\mathrm{Na}$ verdade, os sofrimentos de Cristo tiveram início bem antes de sua detenção e tortura por parte dos soldados romanos. Sua paixão pelo reino messiânico, traduzida através de sua pregação e comensalidade com os excluídos desse mundo, o levaria ao fatal confronto com os sacerdotes do seu povo e as autoridades romanas vigentes. Exteriormente, sua paixão caracterizava-se por sua veemente rejeição como blasfemo por parte dos dirigentes de seu povo e sua

\footnotetext{
${ }^{210}$ Cf. MARDONES, José Maria. Matar nossos deuses: em que Deus acreditar? São Paulo: Ave Maria, 2009, p. 158.

${ }^{211}$ Cf. MOLTMANN, Jürgen. O Deus crucificado., p. 347.

${ }^{212}$ Cf. SOBRINO, Jon. A fé em Jesus Cristo: ensaio a partir das vítimas. Petrópolis, Rio de Janeiro: Vozes. 2000, p. 449.

${ }^{213}$ Cf. MARDONES, José Maria. Op.cit., p. 158.

${ }^{214}$ Cf. MOLTMANN, Jürgen. Op.cit., pp. 348-349.

${ }^{215}$ Cf. MARDONES, José Maria. Op.cit., p. 160.
} 
execução como perturbador da ordem romana, mas interiormente, situava-se no abandono por parte de Deus, seu Abba, Pai, cujo reino apregoava.

Enquanto o Filho em sua entrega sofreu o morrer no abandono, o Pai sofreu a morte do Filho na imensa dor de seu amor por Ele. Sua dor foi correspondente à morte de seu Filho.

Na verdade, no centro da Trindade está a cruz revelando no coração do Deus triúno um amor que pulsa por toda a sua criação. Interna e intensa, a dor trinitária manifesta-se no amor do Pai que se doa transformado em dor por causa da morte e no amor correspondente do Filho que sofre a dor do abandono pelo Pai. Essa mistura de entrega e sofrimento atinge as profundezas da divindade. ${ }^{216}$

Essa intensa comunhão no sofrimento é descrita por Jürgen Moltmann da seguinte forma:

\begin{abstract}
A fraqueza de Jesus foi também a fraqueza de Deus, os sofrimentos de Jesus foram também os sofrimentos de Deus, a morte de Jesus significou também sua morte para Deus, seu Pai: "Eu estou no Pai, o Pai está em mim”, diz o Cristo joanino. Graças a essa inabitação recíproca (perichoresis), do Pai no Filho e do Filho no Pai, os sofrimentos de Jesus são sofrimentos divinos, e o amor de Deus é suscetível a sofrimento e está disposto a sofrer. ${ }^{217}$
\end{abstract}

Entretanto, o Filho entregue pelo Pai não foi apenas o objeto, mas se fez sujeito responsável e resignado (Gl 2,20), seu sofrer e morte constituiu uma passio activa, paixão assumida conscientemente, paixão por Deus antes de tudo. Ele foi obediente até a morte de cruz (Fp. 2,8) e experimentou um aprendizado de entrega no paradoxo do abandono por parte de Deus. ${ }^{218}$

Contudo, na "escura noite” da morte, nasce uma profunda comunhão entre a vontade do Filho e a do seu Pai. O Espírito Santo, divino autenticador e operador dos sinais e milagres realizados por Jesus, une agora Pai e Filho enquanto comunga com os seus sofrimentos. Pois, na entrega de Cristo manifestase também a renúncia do Espírito. Ele também é sujeito na história da paixão. ${ }^{219}$

A entrega que Deus fez do seu Filho, em última instância, foi interpretada como um ato de amor (Jo 3,16). Deus deixa Jesus morrer na cruz para comunicar o seu desígnio de vida ao mundo, consequência de seu grande amor, por isso, os seres humanos devem confiar nesse poderoso e restaurador sentimento divino. $\mathrm{O}$

\footnotetext{
${ }^{216}$ Cf. MOLTMANN, Jürgen. O caminho de Jesus Cristo. p. 268.

${ }^{217}$ Ibid., p. 273.

${ }^{218}$ Cf. Ibid., p. 268.

${ }^{219}$ Cf. Ibid., pp. 268-269.
} 
Deus vulnerável sofre por sua criação. Ele está lá na cruz. Assim, Deus aproximase radicalmente por sua encarnação na história e sem manipulá-la, sofre e morre em profundo ato de amor e comprometimento com a humanidade carente. ${ }^{220}$ Sua encarnação assumiu todas as dores e angústias da humanidade, enquanto sua vocação manifestou seu contínuo e crescente desejo de fidelidade a Deus e aos oprimidos. $^{221}$

\section{6. \\ O caminho da relacionalidade}

Muito distinto de emoções humanas irracionais, tais como desejo, raiva, ansiedade e inveja entre muitas outras, o pathos divino demonstra o interesse de Deus por sua criação, seu povo e seu direito. Deus envolve-se afetivamente com eventos, ações e sofrimentos dos seres humanos. ${ }^{222}$

No Antigo Testamento, a própria lei é oferecida no campo da aliança. Seu pacto indica sua amizade, seu envolvimento salvador entre os seres humanos, fruto de uma amor que em relacionalidade convive e sofre com a humanidade. ${ }^{223}$ Deus não impõe sua palavra e simplesmente se exila de sua criação, Ele não se contenta apenas em ser o fundamento de toda a existência. Antes deseja suscitar

${ }^{220}$ Cf. SOBRINO, Jon. Cristologia a partir da América Latina. Petrópolis, Rio de Janeiro: Vozes. 1983, pp. 123-124.

${ }^{221}$ Cf. BASTOS, Levy da Costa. Os caminhos da salvação. p. 71.

${ }^{222}$ Cf. MOLTMANN, Jürgen. O Deus crucificado. p. 344. Jurgen Moltmann lembra que quando Orígenes descreve o sofrimento de Deus, ele se refere ao co-sentir (sim-patia), que traduz a essência de sua misericórdia. Em misericórdia, Deus participa do sofrimento alheio, assumindo a dor do outro, sofrendo pelo outro. Trata-se de um ato de total alteridade. Esse é para Orígenes o sofrimento divino, a dor do Deus que carrega o mundo enquanto suporta sobre seus "ombros" o seu agravo. Assim o Pai sofre ao entregar o seu próprio Filho (Rm 8,32), assumindo o padecimento necessário a redenção humana, e o Filho sofre pelo peso do nosso pecado e de nossas fraquezas. Orígenes vislumbra uma paixão divina suportada por Cristo, mas que também ocorre em nível trinitário, entre o Pai e o Filho, pois o sofrimento do amor, além de referir-se a ação redentora de Deus ao exterior dele próprio, refere-se também a comunidade trinitária, em seu próprio interior. Existe uma correspondência mútua entre o sofrimento extratrinitário e intratrinitário, Pois a paixão divina de seu amor externo, fundamenta-se na dor de seu amor interno. Cf. MOLTMANN, Jürgen. Trindade e Reino de Deus. pp. 38-39.

${ }^{223}$ O conceito de aliança no Antigo Testamento apresenta uma rica e complexa tradição que percorre a história, objetivando estabelecer firmes parâmetros quanto à sadia relação entre Deus e o seu povo. Uma análise mais profunda de seu significado demonstra que a aliança divina não se atém apenas ao âmbito legal, mas também engloba uma relacionalidade cultual prática. Uma sadia correspondência analógica à aliança transpõe a ideia de um tratado, encontrando também um sentido mais pleno nas relações familiares, no relacionamento entre pai e filho, conforme descrito no pacto davídico (2 Sm 7); no relacionamento entre marido e mulher descrito no livro de Oséias e ainda na afirmação do responsável papel humano conforme enfatizado no evento do Sinai. Essa aliança encontra seu clímax no Cristo encarnado, morto e ressuscitado. Cf. HARRIS, Laird R. (Org.). Dicionário Internacional de Teologia do Antigo Testamento. São Paulo: Vida Nova. 1998, p. 216. 
um espaço de relacionamento amoroso e de liberdade entre os seres humanos. Como Pai, Ele deseja o crescimento saudável e a realização de seus filhos para o desenvolvimento de uma responsável autonomia e como esposo companheiro, integra em amor, uma só carne num mesmo projeto de existência. Por isso, sua aliança manifesta-se na lei do amor como caminho de realização mediante um relacionamento de liberdade e confiança. ${ }^{224}$

Se Deus emergiu de si para criar o mundo e relacionar-se com seu povo em aliança, ele imergiu-se em sua história. Num pathos de livre relacionamento, Deus se envolve ativamente com sua criação e seu povo e sofre pela desobediência de Israel apaixonado por seu direito e honra no mundo. Ele leva o homem tão a sério, a ponto de sofrer por suas ações e sentir-se ferido por elas. Há intensidade afetiva em sua relação com este mundo. ${ }^{225}$

Como descreve Jürgen Moltmann, considerar o pathos divino não é refletir sobre Deus em termos de seu absolutismo, mas sim sobre sua paixão e seus interesses no universo relacional de sua aliança:

Se Deus abriu o coração na aliança com o seu povo, Ele é ferido pela desobediência e sofre nas pessoas. O que o antigo Testamento nomeia de a ira de Deus não pertence à categoria da transferência antropomórfica das emoções humanas inferiores a Deus, mas pertence à categoria do pathos divino. Sua ira é o amor ferido e, portanto, um modo da sua reação ao homem. O amor é a fonte e a base da possibilidade da ira de Deus. A indiferença perante a justiça e injustiça seria uma retirada da aliança por parte de Deus...Como um amor ferido, a ira de Deus não é algo que seja imposto, mas um divino sofrimento do mal. É um lamento que passa pelo seu coração aberto. Ele sofre em sua paixão pelo seu povo. ${ }^{226}$

Esta vívida intensidade relacional entre Deus e o seu povo no ambiente de sua aliança, revela sua historicidade e sua comunhão com o seu povo.

Como reflexo do pathos divino o ser humano se abre a Deus em oração e esperança como homo sympatheticos, tornando-se amigo de Deus e abrindo-se ao presente de Deus em comunhão dialogal. Ele entra em uma unio sympathetica

\footnotetext{
${ }^{224}$ Cf. PIKAZA, Xabier. A figura de Jesus: profeta, taumaturgo, rabino e messias. Petrópolis, Rio de Janeiro: Vozes, 1995, pp. 118-119.

${ }^{225}$ Cf. MOLTMANN, Jürgen. O Deus crucificado. pp. 344-345. O autor faz uma descrição da teologia pática exposta pioneiramente por Abraham Heschel em sua obra The prophets, distinguindo o pathos de Deus daquele expresso por divindades pagãs caprichosas, invejosas e heróicas das sagas míticas, sempre sujeitas ao destino (ananke), observando ainda, que os profetas nunca identificaram o pathos divino com o ser de Deus, que para eles, era algo absoluto, antes, a forma de seu relacionamento com os outros.

${ }^{226}$ Cf. Ibid., p. 346.
} 
com Deus. Ele comunga com a realidade presente de Deus e por isso sofre com o sofrimento de Deus, ama com o amor de Deus, espera com a esperança de Deus. Enfim, comunga relacionalmente através dos sentimentos de Deus. ${ }^{227}$

Com base na pressuposição da eleição da aliança entre Deus e o seu povo basta ao judaísmo o desenvolvimento de uma teologia pática dipolar que fale da paixão de Deus e do mover do Espírito no sofrimento e na esperança do homem. Entretanto, para o cristão, especialmente o gentio, o acesso dialógico com Deus só pode ser possibilitado de forma trinitária mediante o próprio Cristo que comunica a paternidade de Deus e o poder do Espírito. Deus cria, através de Cristo, as condições necessárias para o estabelecimento de um relacionamento de pathos e simpatheia entre Ele e os seres humanos: pecadores, ímpios e abandonados. Tais condições são criadas por meio da auto-humilhação divina na morte do crucificado e pela exaltação do homem na ressurreição de Cristo. Nisto consiste a graciosa abertura divina a todo ser humano, em toda sua miséria. ${ }^{228}$

Por isso, Jürgen Moltmann conclui:

...a teologia cristã deve, portanto, pensar simultaneamente em termos cristocêntricos e trinitários. Somente a aliança feita unilateralmente por Deus e acessível a todos na cruz de Cristo, possibilita os relacionamentos de diálogo da aliança em espírito, em simpatheia e em oração. "Deus estava em Cristo” - essa é a pressuposição para a comunhão dos pecadores e dos ímpios com Deus, já que abre a esfera de Deus para o homem como um todo e para todos os homens. "Vivemos em Cristo" - essa é a consequência para a fé que experimenta a plena comunhão com Deus, em comunhão com Cristo. ${ }^{229}$

Na verdade, o Deus revelado na cruz é aquele atingido pela realidade dos sofrimentos, misérias e injustiças. Ele nunca pode ser considerado um Deus apático ou impassível, mas o Deus-Ágape que se fez homem servidor, aquele que se envolve compadecidamente partilhando da dor de seus amigos, da humanidade com a qual sempre se relacionou. É o Deus que vence o sofrimento pela mediação solidária de seu Filho, Jesus Cristo na cruz. ${ }^{230}$

\footnotetext{
${ }^{227}$ Cf. Ibid., p. 346.

${ }^{228}$ Cf. Ibid., p. 348.

${ }^{229}$ Ibid., p. 351.

${ }^{230}$ Cf. RUBIO, Alfonso Garcia. O encontro com Jesus Cristo vivo. pp. 100-101.
} 


\section{7. \\ O caminho da solidariedade}

Através dos sofrimentos de Cristo, Deus se torna solidário com todos os seres humanos e criaturas onde quer que se encontrem. Pelos sofrimentos de Cristo, Deus está conosco em nossas aflições. ${ }^{231}$

Jürgen Moltmann destaca a solidariedade dessa entrega na crucificação do Filho:

O Pai “entrega” o Filho para tornar-se Pai dos “entregues” por meio dele. (Rm 1, 18s). Isso transforma também o "Pai todo-poderoso", pois Cristo foi "crucificado na fraqueza de Deus” (2 Cor 13,4). O Filho é entregue a morte para tornar-se o irmão e salvador dos condenados e amaldiçoados. ${ }^{232}$

Assim, embora o Pai estivesse com o Filho em seu coração, abandonou-o por um breve instante, para torná-lo irmão dos homens desamparados e para que em sua comunhão com seu Filho nada mais pudesse separar qualquer pessoa do seu amor. ${ }^{233}$

Segundo Moltmann, os sofrimentos de Cristo incluem também os nossos sofrimentos e sua cruz une-se solidariamente a nossa cruz. Assim, Deus participa de nossos sofrimentos levando sobre si as nossas dores. As pessoas sem-nome e sem-número, excluídas, abandonadas e torturadas tornam-se seus irmãos e irmãs. Cristo entra no processo de rebaixamento e abandono para proporcionar, pela força do seu sofrimento e de suas feridas que curam (Is 53,5), a todos os humilhados e abandonados, o amor de Deus. A partir dessa comunhão de sofrimentos nada, nem nenhum sofrimento poderá separar seu povo Dele. ${ }^{234}$

Na descrição sobre a final e completa auto-humilhação de Deus na pessoa de Jesus registrada no capítulo 2 da epístola endereçada aos Filipenses, Ele, em Cristo Jesus, penetra a situação humana circunscrita por limites e finitudes, não somente condescendendo à mesma, mas abraçando-a toda existencialmente:

Conforme Jürgen Moltmann explica:

Ele não somente entra nela, desce a ela, mas também a aceita e abraça toda a existência humana com todo o seu ser. Ele não se torna espírito para que o

\footnotetext{
${ }^{231}$ Cf. MOLTMANN, Jürgen. O caminho de Jesus Cristo. p. 278.

232 Ibid., p. 266.

${ }^{233}$ Cf. Ibid., p. 277.

${ }^{234}$ Cf. Id. Vida, esperança e justiça: um testamento teológico para a América Latina. São Bernardo do Campo, São Paulo: EDITEO, 2008, p. 46.
} 
homem suba primeiro ao Reino do Espírito, a fim de participar com Deus. Ele não se torna simplesmente o parceiro da aliança de um povo eleito, de modo que o homem possa pertencer a esse povo, pela circuncisão e pela obediência à aliança, a fim de entrar em sua comunhão. Ele se humilha e aceita toda a humanidade, sem limites e condições para que cada homem possa participar nele, com a sua vida como um todo. ${ }^{235}$

Portanto, no homem Jesus de Nazareth, Deus assume não somente a finitude do homem, mas também a sua situação de abandono. Na cruz, ele experimenta uma morte que vai além da comum limitação de vida ao ser humano, morte que também envolve um violento processo de desprezo e abandono. Mais do que uma religião que exige a participação humana e consequente correspondência de pensamentos e devoção; do que uma lei que exige participação humana por meio de fiel e resignada obediência; ou do que um simples ideal que objetive, para comunhão do ser humano, um constante esforço consagratório, ele se solidariza com o ímpio e desamparado, tomando sobre si a sua morte para que estes possam experimentar a comunhão com Ele.

Não há nenhuma necessidade de algum tipo de maquiagem ou dissimulação daquele que deseja se relacionar com esse Deus encarnado. A essência de sua experiência relacional emana de sua plena corporalidade humana. Ele assumiu todo desamparo, solidão e rejeição na cruz, como também não somente a sua morte, mas, responsável e apaixonadamente, todas as implicações de sua vida até sua morte de cruz, levando o ser humano a participar de sua vida, sofrimento, morte e ressurreição. ${ }^{236}$

O Deus vulnerável comunica a partir das vítimas, a importante mensagem da radical possibilidade do Deus que tem poder para salvar a criatura sofredora de forma humana, demonstrando sua solidariedade com ela. Trata-se de um Deusconosco, um Deus-para-nós empenhado na superação da solidão, orfandade e indignidade, produzindo no ser humano uma digna e alegre identidade de vida. Assim, aquele que foi crucificado solidariamente apregoa a mensagem da credibilidade, graça e ternura, expressando assim, seu amor, sua afinidade para com seres humanos, alvo do exercício de sua alteridade. ${ }^{237}$

\footnotetext{
${ }^{235}$ MOLTMANN, Jürgen. O Deus crucificado. p. 351.

${ }^{236}$ Cf. Ibid., p. 352.

${ }^{237}$ Cf. SOBRINO, Jon. A fé em Jesus Cristo. pp. 140-141.
} 


\section{8. \\ O caminho da regeneração}

Um novo começo. Esta é sem dúvida a sintética expressão que melhor define o caráter essencial da ressurreição de Cristo. Uma nova ordem é recriada no mundo efêmero. O Cristo que em sua morte de cruz foi tomado de entre os vivos, em sua ressurreição é tomado de entre os mortos, e uma nova era de vida se inicia pelo poder regenerador do Espírito da vida. ${ }^{238}$

A fé da comunidade primitiva na ressurreição não se fundamentava apenas nas aparições de Cristo, mas alimentava-se também, em correspondente medida, pela certeza da ação do Espírito de Deus como “Espírito vivificador” e “poder da ressurreição”. ${ }^{239}$ Por meio dos sofrimentos do Cristo, o Espírito Santo, divino gerador, fará vir à luz a nova criação de todas as coisas. Após um "parto normal” na cruz ela renascerá mediante a ressurreição do Homem de Nazareth, chamado Jesus. $^{240}$

Paulo descreve o Cristo ressurreto como o "primeiro fruto" dos mortos (I Cor 15,20). Após sua morte, o Espírito Santo o regenera para a vida eterna, sua presença vivifica o Cristo ressuscitando-o. Ele é o primogênito dos mortos (Cl $1,18)$.

Na verdade, o Cristo que nasceu em Belém reviveu dos mortos (Rm 14,9; I Cor 15,45). A sepultura foi o lugar do seu renascimento e sua encarnação foi consumada por sua ressurreição e não pela morte de cruz.

Para Paulo, a ressuscitação e o tornar a viver de Cristo constituiu-se numa transfiguração corporal, onde sua glorificação deixou para trás seu estado de humilhação. Assim também, nosso corpo de humilhação será transfigurado para assumir a mesma forma do corpo de glória de Cristo. Esta analogia será concretizada por ocasião da ressuscitação universal dos mortos, quando transições extremamente paradoxais tais como da "corrupção” para a “incorrupção”, da “desonra” para a "glória”, da "fraqueza” para o "poder” e do “corpo natural” para o “corpo espiritual” (I Cor. 15,36) serão plenamente efetivadas. ${ }^{241}$

\footnotetext{
${ }^{238}$ MOLTMANN, Jürgen. Vida, esperança e justiça. p. 59.

${ }^{239}$ MOLTMANN, Jürgen. Quem é Jesus para nós, hoje? Petrópolis, Rio de Janeiro: Vozes, 1996, p. 76.

${ }^{240}$ MOLTMANN, Jürgen. O caminho de Jesus Cristo. p. 278.

${ }^{241}$ Ibid., pp. 372-373.
} 
A morte de Cristo constituiu um ato de solidariedade para toda a criação. Mais do que uma morte violenta, ele morreu a morte trágica da natureza. Além da vida eterna para os mortos, a ressurreição de Cristo trouxe também imperecibilidade de vida para toda a natureza. Por meio do Espírito da vida ele torna-se não somente o Primogênito do renascimento dos mortos, mas de toda a criação $(\mathrm{Cl} 1,15)$.

Por isso, Jürgen Moltmann declara:

A superação do poder da morte por meio do renascimento de Cristo e o derramamento do Espírito divino sobre "toda carne” devem ser considerados, neste contexto, como o grande sinal para a "primavera da criação", para a "ressurreição da natureza” e para a "divinização do cosmo". O "Espírito da ressurreição" que atua em Cristo e, por meio dele em pessoas, é também o Espírito que leva a todas as criaturas vivas para a primavera da vida eterna. ${ }^{242}$

O Espírito Santo é igualmente o criador e o recriador da natureza. Ele é o princípio da glória e o dia da ressurreição de Cristo é o primeiro dia da nova criação.

Cristo não morreu apenas para oferecer a paz reconciliadora aos seres humanos, mas também a toda criação. Como descreve a epístola endereçada aos Colossenses, tudo é reconciliado por meio de Cristo na terra e no céu por meio do seu sangue derramado na cruz $(\mathrm{Cl} 1,20)$. Nele, em sua morte e ressurreição, toda criação caminha para a consumação de uma nova comunhão de paz, quando autoisolamento e individualizações existenciais serão deixados para trás. Pois Cristo, o “cabeça” dessa nova comunhão detém toda a harmonia da "plenitude da divindade” (Cl 2,9). A plena comunhão em Cristo é o destino de toda a criação.

Assim, sua ressurreição dos mortos sempre abrangeu um caráter coletivo, nunca individual. O messias ressurreto abre um horizonte de pleno futuro e esperança em Deus para Israel, bem como para todos os povos e toda a criação que sofre. Seus braços se estendem oferecendo a nova vida recriada por Deus pelo poder do seu Espírito e suas mãos trazem para fora do sepulcro da corruptibilidade toda criatura que geme. Se a morte de Cristo na cruz foi isolada e exclusivamente dele, sua ressurreição, no entanto, é inclusiva abrangendo cosmicamente toda a criação a fim de refazê-la. ${ }^{243}$

\footnotetext{
${ }^{242}$ Cf. Ibid., pp. 378-379.

${ }^{243}$ MOLTMANN, Jürgen. Vida, esperança e justiça. p. 62.
} 
Uma compreensão que restrinja o significado da ressurreição apenas ao nível existencial pessoal ou histórico tangente à esperança humana não conduziria a criação a uma consumação cósmica, mas reducionista e segregada. Cristologias de âmbito existencial e histórico encontram sua consumação plena apenas na cristologia cósmica, pois é na esperança da plenitude da paz divina universal que se abre um horizonte à cura existencial da humanidade. ${ }^{244}$

O corpo do Cristo ressurreto conduz a natureza humana para o Reino de Deus, pois nele se inicia a recriação da vida mortal nesse mundo, o êxodo da humanidade de sua escravidão da morte para a liberdade da nova criação. ${ }^{245}$ Assim, a justiça divina restabelecerá de forma sublime o direito aos vitimados deste mundo, erguendo-lhes do pó e sarando suas mutilações. Seu poder criativo é saúde e nova vida. ${ }^{246}$ Todo poder destruidor e antidivino da morte é banido da criação, ${ }^{247}$ os desesperados e sem perspectivas serão socorridos, os que se encontram “mortos” serão ressuscitados para a vida, pois flui a água da vida e foise embora o tempo da maldição. Abre-se o paraíso e começa a consumação do mundo. $^{248}$

Ele é o protótipo do corpo glorificado, uma promessa corporificada para toda a criação como descreve Jürgen Moltmann:

[...] emana dele um efeito transfigurador. Ele esta traspassado do Espírito vivificador. Por isso emana dele o Espírito que vivifica já aqui. Ele se encontra na luz da perfeição de Deus; [...]. Ele é o corpo perfeito; por isso se baseia nele, a esperança da "ressurreição da carne". Ele participa da onipresença de Deus, por isso, sua presença física não tem mais limitações de espaço. Ele participa da eternidade de Deus, por isso sua presença não mais está condicionada temporalmente. Ele vive no céu das potências criadoras de Deus e reina com elas, e já não está mais sujeito às possibilidades limitadas da realidade terrena. Assim, nele e por meio dele, as forças na nova criação atuam sobre o mundo presente. ${ }^{249}$

Sua primogenitura é vanguarda, liderança. Ele é o líder da vida, da ressurreição da humanidade e da natureza. ${ }^{250}$

\footnotetext{
${ }^{244}$ Cf. MOLTMANN, Jürgen. O caminho de Jesus Cristo. pp. 381-382.

${ }^{245}$ Cf. Ibid., p. 384.

${ }^{246}$ Cf. Id; BASTOS, Levy da Costa. O futuro da criação. Rio de Janeiro. Manuad X; Instituto Misteryum, 2011, p. 39.

${ }^{247}$ Cf. Id. Quem é Jesus para nós, hoje? p. 87.

${ }^{248}$ Cf. JEREMIAS, Joachim. Teologia do Novo Testamento. São Paulo: Editora Teológica, 2004. pp. $170-171$.

${ }^{249}$ MOLTMANN, Jürgen. O caminho de Jesus Cristo. p. 385.

${ }^{250}$ MOLTMANN, Jürgen; BASTOS, Levy da Costa. Op.cit., p. 40.
} 
Portanto, morre com Cristo a fragilidade da natureza humana escravizada pelo poder da morte, renascendo em sua ressurreição a plenitude de vida da nova criação, onde a morte já não tem domínio. A natureza humana do presente mundo é recriada viva e imortal. Inicia-se, pois uma cura não somente humana, mas não humana do mundo. A criação, originalmente boa, é liberta na ressurreição de Cristo e plenamente aprimorada na recriação divina. ${ }^{251}$

Todos ensinamentos vivenciados por Jesus Cristo, o grande Mestre da vida, descritos nesse capítulo, alimentam fecunda esperança de uma sadia interação entre os valores existenciais das boas novas por ele propagadas e as profundas carências que habitam o contexto em que o ser humano pós-moderno encontra-se inserido.

${ }^{251}$ MOLTMANN, Jürgen. O caminho de Jesus Cristo. pp. 385-386. 
A pastoral kerygmática moltmanniana frente às demandas do ser humano pós-moderno

Tendo configurado no primeiro capítulo o ser humano pós-moderno em seu contexto existencial e refletido no segundo capítulo sobre a proposta de vida do Cristo do caminho de Jürgen Moltmann, cabe aqui, nesse terceiro e último capítulo, traçar a correspondência entre sua leitura kerygmática e as demandas do ser humano hodierno.

Jesus Cristo, a mensagem viva, apregoa ao ser humano atual o livre e gracioso amor de Deus compartilhado acima de qualquer interesse. Proclamador das boas novas de liberdade que conduzem o ser humano à reflexão sobre o verdadeiro sentido da existência humana, o Deus crucificado expressa sua sensibilidade em alteridade apaixonada, assumindo responsavelmente seu papel na vida, morte e ressurreição, proporcionado ao ser humano à certeza da sua plenificação, a vitória sobre as limitações dessa vida.

Assinalamos entretanto, que bem distante de nós vai toda e qualquer pretensão de exaurir todas as possibilidades de reflexão sistemático-pastoral ao tema abordado. Antes, visamos fomentar questões que aperfeiçoem uma sadia compreensão da vida no exercício das profundas verdades encontradas no Kerygma de nosso Senhor Jesus Cristo sob a ótica do grande teólogo da vida Jürgen Moltmann.

\section{1. \\ O Kerygma para a sociedade de consumo}

Como características dos séculos XIX e XX, o crescimento do consumo, e as relações pessoais baseadas nas necessidades, conduziram o homem a uma subjetividade como forma de compensação às suas tumultuadas relações sociais, conforme Moltmann a descreve:

É uma sociedade que, pela fundamental emancipação de todos os pressupostos e de todas as ordenações humanas historicamente transmitidas, tem por conteúdo, unicamente a constante e uniforme natureza das necessidades do ser humano como indivíduo e sua satisfação pelo trabalho comum e divisão do trabalho. Segundo sua definição básica, ela não suporta nada que não seja pressuposto na mediação da necessidade da satisfação do indivíduo por meio do seu trabalho e, por meio de 
todos, da satisfação das necessidades de todos os outros. Isso significa que esta sociedade, ao contrário de todas as anteriores, limita-se aquelas relações sociais que ligam o indivíduo entre si pela satisfação das necessidades, como produtores e consumidores. Todo o resto que ainda constitui a vida de um ser humano: cultura, religião, tradição, nação, moral, etc., é excluído das relações sociais necessárias e posto sob a liberdade individual. ${ }^{252}$

Em consequência disto produziu-se uma deformada expectativa de subjetividade, onde o salvamento depende da interiorização do transcendente, observando-se uma espécie de isolamento social, ancorado em uma fé que não gera consequência prática alguma para o próximo, onde os sentimentos de eternidade garantida, e os desejos existenciais e de consumo, são atendidos. ${ }^{253}$ Todo esse clima consumista tem posto em risco a coexistência solidária entre comunidades tradicionais como a família, a sociedade civil e mesmo a própria nação. O custo humano envolvido em todo esse devorador sistema é caro e tem se tornado um grande desafio ao reparo existencial. O mercado tornou-se um sistema penetrante em todas as áreas da vida. ${ }^{254}$

Para Moltmann, as expectativas sócio-eclesiológicas referidas de forma alguma se coadunam com o genuíno perfil teológico da fé cristã. ${ }^{255}$ Ele assevera que o reino de Deus através de Jesus materializou-se na história e a tarefa desta igreja é apregoar a sua antecipação. ${ }^{256}$

O reino de Deus fundamenta teologicamente a Igreja, dando a mesma uma séria incumbência missionária, onde esta compartilha com a sociedade em seus sofrimentos contemporâneos, formulando uma concreta e ancorada esperança em Deus para as pessoas. ${ }^{257}$

A esperança do futuro Reino de Deus é tarefa da igreja quando assume concretamente a sociedade em que está inserida dando um horizonte de justiça, vida e humanidade. E isso se dá missionariamente através da pregação do evangelho. Sua missão é proclamar e despertar uma esperança viva, ativa e

\footnotetext{
${ }^{252}$ MOLTMANN, Jürgen. Teologia da esperança: estudos sobre os fundamentos e as consequências de uma escatologia cristã. São Paulo; Teológica/Loyola, 2005, p. 383.

${ }^{253}$ Cf. Ibid., pp. 387-394.

${ }^{254}$ Cf. MOLTMANN, Jürgen. Liberdade e comunidade na era do individualismo e globalização. In: KOHL, Manfred W.; BARRO, Antônio Carlos (Org.) A igreja do futuro. Londrina, Paraná: Descoberta. 2011, p. 24.

${ }^{255}$ Cf. MOLTMANN, Jürgen. Teologia da esperança. p.403.

${ }^{256}$ Cf. Ibid., p.408

${ }^{257}$ Cf. MOLTMANN, Jürgen. Experiências de reflexão teológica: caminhos e formas da teologia cristã. São Leopoldo; Unisinos, 2004, p. 13.
} 
apaixonada pelo reino de Deus e seus valores vivenciados por Jesus, conforme o evangelho. $^{258}$ Portanto, tais valores e propostas prático-existenciais de vida proclamados por Jesus e entregues a igreja para divulgação ou semeadura na sociedade em que vive, ancoram a fé em uma experiência de vida cotidiana significativa, e concreta, onde o ser humano experimenta uma ordem cívica humanizada e equilibradamente e perene.

Apesar de não proporcionar ainda o fim das carestias da vida nesse mundo e uma plenitude consumada, o evangelho conduz os pobres à bem-aventurança da nova dignidade peculiar aos concidadãos do Reino. O atual e perverso sistema de valores criva a dignidade de um ser humano por sua capacidade de consumo e bens que possui. O homem realizado e, por conseguinte vencedor é o que pode consumir. Se não o faz é visto como fracassado na luta pela vida. Assim, a pobreza se torna auto-destruidora e produtora de ódio. ${ }^{259}$

O evangelho do Reino de Deus é dirigido na plenitude do Espírito aos pobres. O anúncio do imediato e infindável governo de Javé ${ }^{260}$ que devolverá a dignidade aos pobres, fazendo-lhes veículo do futuro de Deus, alvo de seu caminho de comunhão e compartilhamento, de bênçãos que transcendem avaliações meritórias ou compensadoras na sociedade em que vivem. Eles são a mensagem viva da graça de Deus. ${ }^{261}$

Conforme o Sermão da montanha, fazem parte da comunidade das bemaventuranças todos os desfavorecidos. Os paradoxos dessa mensagem clarificam o verdadeiro sentido da graça, do Deus que ama incondicionalmente, o que nos impulsiona a amar ao próximo com a mesma gratuidade com que somos amados. Trata-se de uma experiência vivificante, que inspira a reprodução de uma generosa correspondência aos nossos mais humildes semelhantes. ${ }^{262}$

Nessa verdade, os convertidos fundiram-se com os pobres em uma nova comunidade messiânica. Ricos exercitaram-se em comiseração e condescendência enquanto a comunidade messiânica prosperava existencialmente. ${ }^{263}$

\footnotetext{
${ }^{258}$ Cf. MOLTMANN, Jürgen. Teologia da esperança. p. 408.

${ }^{259}$ Cf. Id. O caminho de Jesus Cristo: cristologia em dimensões messiânicas. São Paulo; Academia Cristã, 2009. p. 163.

${ }^{260}$ Cf. Ibid., p.156.

${ }^{261}$ Cf. Ibid., p. 164.

${ }^{262}$ Cf. RUBIO, Alfonso Garcia. O encontro com Jesus Cristo vivo: um ensaio de cristologia para os nossos dias. São Paulo, Paulinas, 2007, p. 56.

${ }^{263}$ Cf. MOLTMANN, Jürgen. O caminho de Jesus Cristo. p. 166.
} 
As escrituras relatam que após o acontecimento do Pentecostes, a primeira comunidade cristã consistia de uma multidão de fiéis com um só coração e uma só alma, que não considerava propriamente sua as propriedades que possuíam. Viviam uma verdadeira relação comunitária. Uma solidariedade mútua entre todos os fiéis dava verdadeiro testemunho de vida acerca do significado da ressurreição de Cristo já aqui em sua sociedade, pois pessoas eram supridas em suas necessidades circunstanciais (At 4,32-35). Os crentes de todas as eras podem encontrar aqui um concreto fundamento norteador para a verdadeira práxis social solidária, pois enfermidade da privação que faz morrer a esperança humana dá real lugar plenitude de vida, a vida real, onde uma Cristoprática de vida faz ressuscitar aqueles outrora excluídos do gozo da vida, mergulhados em sua miséria, privados do suprimento de suas necessidades básicas cotidianas: comer e beber. A vida de Cristo veio sobre estas pessoas, através da amorosa mensagem de alteridade e provisão. Entre pessoas desconhecidas nasceu uma comunidade cuja maior marca identificadora era a da posse de um mesmo coração e alma (At 4,32), que dispensava seguranças ambíguas proporcionadas por bens ou propriedades, destinando esses ao consumo daqueles que necessitavam. Tal sentimento transcendia todas as separações, humilhações e alienações entre seus membros. Desapareciam as barreiras discriminatórias de raça, classe e gênero comuns a uma sociedade socialmente insensível enquanto o amor fraternal reinava entre senhores e escravos, homens e mulheres. Pois havia mútua confiança comunitária, e a reciprocidade do amor se experimentava uma presença tão poderosa de Deus que os fazia superar todo o antigo potencial para o medo e agressões entre si. A força de comunhão do Espírito era neles mais forte do que tudo aquilo que os podia separar. Eles realmente passaram a experimentar um caminho de vida sobremodo excelente (I Cor 13).

O dado mais relevante de toda essa experiência de Deus é a sua realidade. Os primeiros cristãos a viveram e experimentaram sua eficácia em sua sociedade. Ela é possível ainda hoje ante as desigualdades e privações sociais da atualidade, onde o ponto nevrálgico de tensão é percebido numa injusta luta por alimentos e satisfações entre ricos e pobres, fortes e fracos, saudáveis e doentes, dominadores e subalternos onde predomina um desesperado sentimento de auto preservação 
fomentado por uma desenfreada ambição por aquilo que muitos pensam que seja a vida. Nessa sociedade, cada um se considera seu próprio próximo.

Assim, a solução para a pobreza não consiste diretamente de prosperidade financeira, de uma riqueza monetária, mas sim existencial, como afirma Jürgen Moltmann:

O oposto da pobreza não é riqueza, mas comunidade. Em comunidade, os indivíduos ficam ricos, ricos de amigos em que se pode confiar, ricos de auxílio mútuo, ricos de idéias e forças, ricos das energias da solidariedade. Essas energias apenas estão ociosas ou são suprimidas. Todas as ações solicitas surgiram na base: jardins de infância, auxílio entre vizinhos, assistência aos pobres, cuidado dos doentes e outras "iniciativas cidadãs". ${ }^{264}$

Portanto, importa proclamar a mensagem de prosperidade do Reino de Deus, aquela que tem como base a realidade do compartilhamento mútuo experimentado pela verdadeira humanização materializada, uma riqueza existencial, ${ }^{265}$ pois “a felicidade de uma vida bem sucedida depende das relações sociais e da auto-referência, não do excesso de bens materiais”. 266

Verdadeiramente o Reino de Deus deve proporcionar transformação não somente as pessoas, mas também as estruturas em que as mesmas vivem. Uma transformação pessoal e interior sem uma mudança nas circunstâncias estruturais seria uma ilusão idealista, daqueles que veem apenas a alma do ser humano, esquecendo-se do seu corpo. Entretanto, sabe-se que também, uma mudança de caráter tão somente exterior, caracteriza uma simplória ilusão materialista, muito insuficiente, se não for a consequência de uma transformação interior do próprio ser humano que se encontra inserido na referida estrutura. ${ }^{267}$

A missão libertadora de Cristo não ocorre nas fronteiras entre a alma e o corpo ou entre a pessoa e a estrutura em que vive, mas na tensão diária entre os poderes efêmeros desse mundo e a forças do espírito e do futuro.

As forças vindouras da nova criação encontram-se atuantes em todos os âmbitos da vida combatendo todo pernicioso sistema que atenta contra o fluir da verdadeira vida. Elas lutam pela cura, justiça e liberdade da sociedade. Na

\footnotetext{
${ }^{264}$ MOLTMANN, Jürgen. Ética da esperança. Petrópolis, Rio de Janeiro. Vozes. 2012, pp. 187189.

${ }^{265}$ Cf. Id. O Deus crucificado: a cruz de Cristo como base e crítica da teologia cristã. São Paulo; Academia Cristã, 2011, p. 43.

${ }^{266}$ Id. Ética da esperança. p. 186.

${ }^{267}$ Cf. Id. O Deus crucificado. p. 43.
} 
liberdade da fé e no exercício da oração é que se vive a experiência do espírito antecipadora ao futuro de Cristo e da criatura liberta. ${ }^{268}$

Na solidariedade do crucificado faz-se notório o seu amor desinteressado pelos menos favorecidos e abandonados, os oprimidos pelo perverso sistema que os faz padecer o desprezo desse mundo e os sofrimentos de sua sociedade. A mensagem do crucificado se solidariza com a miséria dos oprimidos e também dos opressores, pois é anúncio da graça divina, irrestrita e desinteressada com a qual precisamos nos identificar como crentes, como explica Jürgen Moltmann:

No que a identificação cristã com o crucificado se afasta das inevitabilidades e trivialidades deste mundo alienado, ela leva o crente necessariamente para a solidariedade com os alienados deste mundo, com os desumanizados e com os indivíduos cruéis. Por outro lado, essa solidariedade só será radical se ela seguir a identificação do Crucificado com os abandonados, aceitar o sofrimento do amor criador e não perseguir sonhos de onipotência por um futuro ilusório. ${ }^{269}$

Longe de qualquer utopia sobre um futuro distante, a mensagem do evangelho prenuncia em caráter sacramental a salvação que já irrompe fazendo o Deus vindouro presente em forma de palavra. A era messiânica já vigora mediante o promissor e libertador anuncio. ${ }^{270}$

\section{2. \\ O Kerygma para a sociedade da subjetividade afetiva}

É positiva a contribuição crítica pós-moderna que nos faz lembrar de que nossa humanidade não consiste apenas da dimensão cognitiva. Nosso empenho intelectual apenas, não poderá nos colocar em contato com toda a dimensão da realidade humana, nem muito menos conduzir-nos a descoberta de todos os aspectos da verdade divina. Na experiência de acolhimento e expressão da fé cristã existe um lugar exclusivo para o “mistério”, um apregoador de que a realidade divina sempre transcenderá a racionalidade humana. ${ }^{271}$

Com o mistério retorna também o misticismo, esquecido há muitos anos e sufocado pela modernidade, onde a informação produziu respostas mais ágeis de conhecimento e instrução bíblica. Atualmente, ante a onipresença do

\footnotetext{
${ }^{268}$ Cf. MOLTMANN, Jürgen. O Deus crucificado. p. 43.

${ }^{269}$ Ibid., pp. 44-45.

${ }^{270}$ Cf. Id. O caminho de Jesus Cristo. p. 156.

${ }^{271}$ Cf. GRENZ. Stanley J. Pós-Modernismo: um guia para entender a filosofia do nosso tempo. São Paulo: Vida, 2008, p. 241.
} 
conhecimento e informação, a oferta supera a demanda relativizando seu valor. Assim, ressurge nas pessoas a sede por aquilo que não somente pode instruí-las, mas transformá-las, elevá-las espiritualmente. Elas desejam viver aquilo que pode diferenciá-las existencialmente, uma verdadeira experiência com Deus. ${ }^{272}$

Por isso, nossa mensagem não deverá limitar-se a uma abordagem proposicional doutrinária reducionista da fé cristã, mas a percepção e comparecimento de outras demandas ou dimensões do ser humano. Na verdade, experiências e conceitos interpretativos caminham juntos, pois enquanto os conceitos contribuem para o melhor entendimento das experiências que vivemos, nossa experiência molda os conceitos por nós empregados ao refletirmos sobre nossas vidas. $^{273}$

O Teólogo José Comblin explica que a maior manifestação da verdade divina aqui nessa terra se deu no amor do Deus revelado mediante seu Filho Jesus Cristo, conforme registrado no evangelho de João, acima de quaisquer princípios morais imutáveis e universais:

Ora, no evangelho segundo João a verdade é o próprio Jesus. 'Eu sou... a verdade” (Jo 14,6). Jesus é a verdade porque nele e por meio dele se manifesta o verdadeiro Deus e a verdade de Deus. Ora, a verdade de Deus que Jesus manifesta é a de que Deus é amor. A verdade é que Deus é amor e esta verdade torna-se manifesta em Jesus. Sendo a verdade, Jesus é também o caminho, porque somente ele pode levar ao amor de Deus. Segundo João, a verdade não se refere a nenhuma lei, não se refere a princípios morais, e muito menos a princípios imutáveis. ${ }^{274}$

Portanto, a proclamação do evangelho de nosso Senhor Jesus Cristo, não deve ser reduzida tão somente a uma lista de proposições corretas, mas deve abarcar verdades teológicas que deem significado a vida das pessoas, expondo a graça de Deus, seu amor e desejo de proximidade, o acolhimento ao ser humano em todas as suas limitações e misérias, algo que faça o homem repensar a sua existência, o seu caminho, que o inspire a jornada de vida proclamada pelo Cristo que almeja um ser humano a medida da estatura de sua plenitude $(\mathrm{Ef} 4,13)$. Tratase de uma cognoscibilidade dinâmica que se empenha na compreensão da experiência humana e suas implicações para a vida. ${ }^{275}$

\footnotetext{
${ }^{272}$ Cf. MCLAREN, Brian D. A igreja do outro lado. São Paulo: Palavra, 2008, p. 276.

${ }^{273}$ Cf. GRENZ. Stanley J. Pós-Modernismo. p. 242.

${ }^{274}$ COMBLIN, José. Cristãos rumo ao século XXI: nova caminhada de libertação. São Paulo: Paulus, 1996, p. 91.

${ }^{275}$ Cf. GRENZ. Stanley J. Op.cit., pp. 242-243.
} 
O conhecimento que temos sobre as coisas que realmente importam em nossa vida se dá em âmbito de probabilidade. Valores éticos, atitudes sociais e crenças religiosas, entre outros, não podem ser provados com certeza. Assim, a fé cristã faz-se ideal companheira do empenho e da aposta na credibilidade desses valores. Na história, razão, experiência e revelação ela encontra equilíbrio e estabilidade, embora sua essência demande aventura, risco, probabilidade manifesta em muitas batalhas em meio a constantes e diversas dificuldades. Aí ela floresce e mostra sua pertinência. Ela não se preocupa com provas exteriores imediatas, mas se sente a vontade ante o conceito externo da possibilidade. Muitas vezes seu investimento é de longo prazo, mas seu duro exercício conduz o ser humano a uma maturidade existencial. ${ }^{276}$

Quando de forma puramente racionalista a doutrina se sobrepõe ao afeto, perde-se campo em uma das principais qualidades inerentes ao evangelizador: a empatia. A mensagem do evangelho precisa ser apresentada de maneira viva e contextualizada ao ser humano que a recebe. Ela deverá ser mais que um lindo "boneco de barro". Recebendo o fôlego de vida do Espírito que usou Jesus a comparecer mediante seu anúncio as pessoas em suas preocupações, demandas e dúvidas, ela se tornará também “alma vivente”. Jesus proclamou palavras de vida aos seus ouvintes (Jo 6,63). Sistemas, idéias e soluções cartesianas apenas, não contemplam o outro em seu contexto real, transformando-se por vezes em grilhões legalistas que não oferecem o acolhimento e a compreensão devida ao outro na particularidade de sua carência existencial. ${ }^{277}$

Conforme considera Jürgen Moltmann:

...se o homem, perturbado com suas questões existenciais, só perceber as coisas no horizonte de sua própria subjetividade, então ele não entenderá nada que não tiver sentido para ele mesmo e que não se relaciona a sua práxis e a compreensão de si mesmo. $^{278}$

Em correspondente sensibilidade, para que o proclamador seja capaz de se comunicar com a subjetividade do outro, relações empáticas precisam ser

\footnotetext{
${ }^{276}$ Cf. MCGRATH, Alister. Apologética cristã no século XXI: Ciência e arte com integridade. São Paulo: Editora Vida. 2008, pp. 154-155.

${ }^{277}$ Cf. RUBIO, Alfonso Garcia. Evangelização e maturidade afetiva. São Paulo: Paulinas. 2006, pp. 203-206.

${ }^{278}$ MOLTMANN, Jürgen. O Deus crucificado. p. 126.
} 
fecundadas na graça de Deus e na doação própria do referido anunciante, sendo realmente vivenciadas para que a mensagem ganhe aplicabilidade concreta e singular na vida do ouvinte, caso contrário o trabalho pastoral correrá o sério risco de ser reduzido um relacionamento intelectual, árido e burocrático, algo deveras superficial à verdadeira plenitude de alcance objetivada no anúncio das boas novas de Jesus Cristo. ${ }^{279}$ Além do mais, uma comunicação afetuosa fará fluir progressivamente um sentimento comunitário que solucionará atritos, mágoas e ressentimentos, problemas tão comuns que emperram o crescimento de várias comunidades eclesiásticas.

Nessa época em que todos os fragmentos sinalizam uma pluralidade inviabilizadora de um único absoluto, o Reino de Deus realmente precisa contemporanizar-se ao ser humano pós-moderno mais por vias relacionais que racionais. Seu anúncio deve ser apregoado tal como o é: proposta de vida. ${ }^{280}$ Não se trata o relativismo atual apenas a partir de proposições conceituais ou ainda por apologética ferrenha, mas conduzindo ao ser humano ao conhecimento relacional de Jesus e a uma verdadeira experiência com Ele. Acolher o amor de Deus é assumir livremente a Palavra viva que é Jesus Cristo como sentido e proposta para o próprio viver, obtendo assim referenciais éticos objetivos e fundamentais para a vida humana. ${ }^{281}$

Conforme assevera Jürgen Moltmann:

Quem compreende a relatividade da relatividade irá parecer relativista, i.e. colocarse na situação do outro, o que não significa, abrir mão de si mesmo. A relacionalidade do próprio ponto de vista a respeito dos outros significa viver em situações concretas e pensar o próprio em relação ao alheio... Assim, essa relacionalidade pode superar o absolutismo da ideologia unitária e o totalitarismo do relativismo. Neste sentido, a mais nova "teologia política" tentou transpor o velho modelo de verificação da "teologia natural”, a qual, sempre foi, de fato, a religião social predominante, da ortodoxia para um novo modelo de verificação da teologia em ortopraxia social e política... Mas a verificação também pode significar por meio do verum facere, realizar, e assim, tornar experienciável, aquilo que ainda não é admitido como amplamente experienciável. Este é o caminho da ortopraxia. Realizar algo e torná-lo experienciável só é possível e razoável em relações vivas

${ }^{279}$ Cf. RUBIO, Alfonso Garcia. Evangelização e maturidade afetiva. pp. 203-206.

${ }^{280}$ Cf. PURIM, P.R. Pós-modernidade e proclamação. Net, Rio de Janeiro, fev. 2006. Disponível em: < http://kerigmaonline.blogspot.com/2006 02 01archive.html> Acesso em: 25 jul. 2011

${ }^{281}$ Cf. RUBIO, A. G. Novos rumos da antropologia teológica. In: RUBIO, A. G..(Org.) O Humano integrado: abordagens de antropologia teológica. Rio de Janeiro: Vozes, 2007, pp. 293294. 
com os outros. A relacionalidade da teologia cristã, portanto, pode ser um caminho razoável entre teocracia absolutista e tolerância improdutiva [...]. ${ }^{282}$

Portanto, teologias esboçadas que pretendem fazer da vida cristã algo realmente relevante ao ambiente ao seu redor, precisam observar esta relacionalidade.

Jesus pregou seu evangelho não somente através de palavras, mas por sua relacionalidade, sua manifestação messiânica se deu em sua correlação com os carentes de sua sociedade, ${ }^{283}$ seu conteúdo kerygmático foi assim absorvido. Ele os contemplou como uma multidão “que não têm pastor”, sem identidade religiosa e etnicamente reconhecível. Ele os ensina, eles os trazem seus doentes e Ele os cura, e estes o acompanham. ${ }^{284}$ Em Jesus e seu Kerygma pastoral aos necessitados encontramos a mais impactante e marcante linguagem existencial e relacional, pois Ele se torna a sua direção, e eles se identificam com sua proposta de vida. Sua ortodoxia, materializa-se se adequando ao concreto responso proclamativo ortopráxico e a complexa situação existencial de sua época. Sua prioridade era a vida, as pessoas e suas demandas.

Portanto, no que tange a um saudável amadurecimento de fé comunitária e pessoal, o desenvolvimento relacional dialógico e afetuoso é ingrediente indispensável à pastoral kerigmática atual. ${ }^{285}$

O universo ético proposto pelo Senhor Jesus em seu sermão do monte, baseia-se no discipulado da vida e na comunhão. Ensino e relacionalidade estão profundamente interconectados. Sua torá messiânica não encoraja seus discípulos ao isolamento ou a discriminação, mas a inclusão das diversas classes de pessoas. Ela é caminho de sabedoria para a vida. A assimilação de seu etos é favorecida pelo vivo veículo da comunhão. ${ }^{286}$

$\mathrm{Na}$ busca de um real sentido à sua vida, o ser humano pós-moderno necessita obter algo que vá além de simples fatos concretos, por isso clama por um instrumento de reflexão e expressão que estabeleça significativos valores, propósito, missão, paixão, fé e espírito. A modernidade produziu abundante chuva de conhecimento, fatos inquestionáveis, mas descombinados, excludentes aos

\footnotetext{
${ }^{282}$ MOLTMANN, Jürgen. O Deus crucificado. p. 28.

${ }^{283}$ Cf. Id. O caminho de Jesus Cristo. p. 227.

${ }^{284}$ Cf. Ibid., p. 231.

${ }^{285}$ Cf. RUBIO, Alfonso Garcia. Evangelização e maturidade afetiva. p. 218.

${ }^{286}$ Cf. MOLTMANN, Jürgen. O caminho de Jesus Cristo. pp. 198 - 199.
} 
teares da imaginação e da fé que poderiam tramar um tecido social norteado por uma sabedoria prática para a vida cotidiana das pessoas. Na verdade, muitas das conquistas modernas não demonstravam um direto comprometimento ou preocupação de valor e significado ético, não exercendo também qualquer tipo de efeito terapêutico às enfermidades existenciais. ${ }^{287}$

O conhecimento e sua admiração pela descoberta não basta a nossa demanda de vida. A sabedoria é o conhecimento do conhecimento, ela surge da experiência. É a boa ética na vida de quem desenvolve uma consciência sadia sobre aquilo que conhece, quem não apenas desbrava, mas administra equilibradamente suas descobertas. Aquele que sabe como convém saber (I Cor 8,2). A sabedoria faz o ser humano transcender o cognoscível prosseguindo em busca de um retorno a si mesmo. A alma humana fecha suas portas para um "balanço”, um exercício de reflexão sobre a utilidade e o saldo positivo à sua vida advindo do conhecimento que adquire. Ela é o verdadeiro aferidor da real valoração daquilo que conhecemos.

As tradições bíblicas denominam esse retorno a si mesmo de o temor ao Senhor. A reverência contida nessa expressão vai além de qualquer tipo de sentimento de medo ou pavor ante a presença de Deus, abarcando um universo de deslumbre, fascinação, consideração e reconhecimento, uma reverencia a sua sabedoria, fruto da sublimidade do Deus didático que supera todas as nossas expectativas. O Deus que acolhe em bondade inesgotável nossa auto-entrega de fé, nossa avidez pelo aprendizado quanto ao seu sábio agir na história de cosmo, da vida humana e de nossa vida. O temor a esse Deus deve ser desenvolvido numa relação de amor apaixonado, ${ }^{288}$ daquele tipo de sentimento que fascinou o apóstolo Paulo, quando se despojou de todos os rudimentos de uma ortodoxia morta por causa da sublimidade do conhecimento de Cristo, Sabedoria de Deus e agora seu Senhor, que deu novo sentido a sua vida de fé (Fil. 3,4-8). ${ }^{289}$ Temor e amor a Deus descrevem respectivamente a sublimidade e a intimidade envolvidas em nosso relacionamento com Deus. ${ }^{290}$ Portanto, são fatores que excedem um

\footnotetext{
${ }^{287}$ Cf. MCLAREN, Brian D. A igreja do outro lado. p. 275.

${ }^{288}$ Cf. MOLTMANN, Jürgen. Experiências de reflexão teológica. pp. 279-280.

${ }^{289}$ Cf. MURPHY- O’ CONNOR, Jerome. Jesus e Paulo: Vidas paralelas. São Paulo: Paulinas. 2008, pp. 103-104.

${ }^{290}$ Cf. MOLTMANN, Jürgen. Experiências de reflexão teológica. p. 280.
} 
simples empenho no conhecimento de Deus através de pura ortodoxia, eles envolvem uma experiência existencial eivada de vida e sentimento.

As condições do conhecimento humano envolvidas em âmbito referido ressaltam o respeito e a dignidade própria do objeto conhecido. É no temor a Deus que reverenciamos a vida humana na qual sua sabedoria opera, bem como suas peculiaridades. Assim, desprezamos toda a opressão e dominação como formas legítimas de exercício de um verdadeiro aprendizado. Apaixonamo-nos pelo empenho de sua sabedoria oculta em tudo que existe, aprendendo a enxergar o ser humano pela ótica de Deus, como Ele o vê existindo, desenvolvendo sua sensibilidade e critério humanizador. Nosso amor a Deus nos faz sábios à medida que nos discípula ao verdadeiro conhecimento mediante o exercício do amor que convive com o próximo respeitando suas particularidades, estabelecendo assim, uma relacionalidade norteada pela sabedoria e simpatia.

Por isso, na verdade, o temor a Deus nos ensina administrar os conhecimentos obtidos, ressaltando acima de todo éthos de saber científico ou ortodoxo, também o éthos do procedimento, da ortopraxia, aquele que serve a vida e luta pela qualidade de uma existência digna. ${ }^{291}$ Uma sabedoria que não deseja dominar, mas sim interagir, inter-relacionando-se com o próximo, comunicando vida verdadeira.

Depois de tantos avanços científicos que marcaram o período moderno, necessitamos explorar aplicadamente a sabedoria que nos ensinará a lidar com o nosso saber, pois a vida futura da humanidade nesse planeta depende dela (Ecl 7, 12). ${ }^{292}$

Portanto a relacionalidade por seu veículo afetivo e a sabedoria por sua plausibilidade existencial a vida humana hodierna, constituem necessários ingredientes pastorais a proclamação do Kerygma na atualidade.

\section{3.}

\section{O Kerygma para a sociedade secularista}

Uma das questões discutidas atualmente no campo da ética cristã versa sobre o papel dos cristãos na elaboração de noções superiores, que possam

\footnotetext{
${ }^{291}$ MOLTMANN, Jürgen. Experiências de reflexão teológica. p. 281.

${ }^{292}$ Ibid., p. 283.
} 
contribuir com soluções às demandas sociais e políticas existentes em nossa sociedade. Estariam os cristãos então, deixando-se levar pela correnteza das águas de uma ética comum ou natural conveniente ao momento em que vive a humanidade? E caso resolvesse posicionar-se numa sociedade tão pluralista, seu padrão de conduta não seria classificado como algo tão singular com uma validade sob medida apenas para ela própria? ${ }^{293}$

$\mathrm{Na}$ verdade, seria incorreto reduzir a mensagem de Jesus a simploriedade de um anúncio religioso, apolítico ou até mesmo apocalíptico, algo que certamente seria irrelevante às transformações objetivadas por ele a esse mundo. Suas pretensões não se atinham às suas conveniências particulares ou pessoais, mas visavam abranger a difícil situação de sua sociedade. Por isso, seu messianismo se revestiu de uma relevância existencial pública e ele se tornou uma ameaça à opressão romana de sua época. Sua Torá messiânica forneceu a devida luz e direção ao seguimento de um sadio caminho ortopráxico para seu povo e também todos os povos da terra. Ela objetivou uma mudança social pela instalação de uma ética cristã. Portanto a resposta social da igreja sempre terá haver com o messianismo de Jesus Cristo expresso em seus valores éticos no seguimento do seu caminho. ${ }^{294}$

Numa sociedade pós-cristã, onde o atual sistema social tem conduzido a humanidade e a natureza à degeneração e até a morte, faz-se extremamente necessário que brilhe sobre o ser humano a luz inconfundível do singular ethos do discipulado cristão que associa a fé em Cristo a uma ética abrange a toda vida. ${ }^{295}$ Uma plausível alternativa de vida, em contraste com a violenta e injusta proposta existencial apresenta pelos atuais sistemas políticos, sociais e econômicos reinantes que destroem o ser humano e a natureza. ${ }^{296}$

Fazendo referência a dois basilares da Reforma Protestante, Jürgen Moltmann reforça a referida idéia:

\footnotetext{
293 Jürgen Moltmann discute a relevância de uma participação ética cristã específica ante as demandas sociais e econômicas da pluralista sociedade hodierna. O autor elenca temas como legislação fiscal e tecnologia genética e afirma que apesar dos cristãos tornarem-se anônimos na vida pública de sua sociedade atual, como pessoas iguais as outras que são, deveriam agir também com mais racionalidade objetiva e responsabilidade no que tange ao seu papel social. Cf. MOLTMANN, Jürgen. O caminho de Jesus Cristo. p. 184.

${ }^{294}$ Cf. Ibid., pp. 185 - 186.

${ }^{295}$ Cf. Ibid., pp. 186 - 187.

${ }^{296}$ Cf. Ibid., p. 192.
} 
O solus Christus da Reforma não pode ser normativo apenas para a doutrina de fé, mas tem que ser normativa também para a ética, pois solus Christus significa também totus Christus: Todo o Cristo para toda a vida...Isso, porém, significa que cristologia e cristoprática se fundem, de forma que um reconhecimento global de Cristo não marca apenas a cabeça e o coração, mas toda a vida na comunhão de Cristo, e que, ao mesmo tempo, Cristo não é reconhecido apenas com a cabeça e o coração, mas na experiência e na prática de toda a vida. ${ }^{297}$

Portanto toda singularidade ética de tudo o que Cristo ensinou e vivenciou, constitui parâmetro seguro, saudável e conveniente a ser experimentado pelo ser humano da sociedade hodierna.

O exercício da liberdade humana se reveste de um significado cívico especial quando vivencia as propostas existenciais do reino de Deus. Assim, a liberdade e autonomia do indivíduo deve ser fundamentada como um dom de Deus acolhido, sendo reafirmada não somente como um direito do ser humano, mas como uma oportunidade cívica do Reino, visando uma gerência responsável para consigo, seus semelhantes e o mundo a sua volta. ${ }^{298}$ Para uma gestão criativa desta gerência, segundo Moltmann, faz-se necessária a particular manifestação da individualidade de cada um. Pois, uma comunhão somente é criativa na medida em que as pessoas participantes o são individualmente. Do contrário, tende-se ao conservadorismo. Por isso, somente pessoas individuais são criativas. As comunhões humanas se renovam em suas pessoas. ${ }^{299}$ Portanto, a mensagem do Reino deve fomentar a participação cívica, responsável e criativa do indivíduo, rejeitando toda alienação ou omissão ao devido envolvimento deste com sua realidade contextual.

Quando nos referimos à questão da alienação, convém ressaltar que a mesma pode se dar também na esfera de vida pessoal. A experiência pessoal constitui atualmente algo de muita significação para a religião. Uma fé que não possa ser experimentada pessoalmente funciona como fator alienante a pessoa que diz possuí-la. ${ }^{300}$

A esfera privada é na atualidade, o local de residência da religião. As mais variadas mediações foram dispensadas enquanto a religião era acolhida e instalada no ambiente do fórum interno da consciência humana. Ali, o ser humano discerne e aprecia as verdades a ele apresentadas pelo crivo afetivo dos sentimentos

\footnotetext{
${ }^{297}$ Ibid., pp. 186 - 187.

${ }^{298}$ RUBIO, A. G. Novos rumos da antropologia teológica. p. 292.

${ }^{299}$ MOLTMANN, Jürgen. O caminho de Jesus Cristo. p. 400.

${ }^{300}$ COMBLIN, José. Cristãos rumo ao século XXI. pp. 324-325.
} 
gratificantes advindos de suas experiências. Na ruptura de sua forma tradicional, a transcendência retorna sem rostos, identidade ou absolutos, uma sede de Deus, por parte de um ser humano em contínua autotranscendência. ${ }^{301}$

A mensagem aos seres humanos, em sua historicidade concreta, é a própria e exclusiva experiência de Deus que teve Jesus de Nazareth testemunhada e seguida por seus discípulos e vivenciada por sua igreja pelo poder do mesmo Espírito que agiu em Jesus. ${ }^{302}$ Desde seu início, a fé cristã se desenvolveu com base na crença do testemunho de outros. Os próprios discípulos reconheceram a Jesus como Testemunha Fiel, e pelos testemunhos de frágeis e limitados seres humanos a proposta de vida de seu Mestre foi apregoada ao mundo. ${ }^{303}$

O testemunho de uma pessoa constitui uma importante e poderosa proclamação silenciosa que ao invés de afirmar verdades teóricas, conduz os seres humanos ao seu redor a levantar dentro de si importantes questões de reflexão existencial alimentas pela conduta da pessoa por eles observada. Torna-se irresistível a curiosidade daquele que deseja saber o que inspira tal comportamento singular. É realmente, poderosa mensagem de vida aos que o veem. A igreja não deve apenas preocupar-se em proteger a fé de seus fiéis, mas também em cumprir a sua singular missão como fermento que se introduz a massa (Mt 13,33) e sal que se mescla aos alimentos temperando-os saborosamente (Mt $5,13) .^{304}$

Entretanto, faz-se necessário também que os cristãos testemunhem coletivamente, através de uma comunidade que viva de forma inspiradora, uma fascinação para que outras pessoas desejem conhecê-la. Uma comunidade que ofereça uma alternativa radical de vida baseada na relação familiar daquele que chama Deus de “Abba”, Pai (Rm 8,15); na igualdade fraternal (Mt 23,8-10); no serviço mútuo ao próximo (Mt 20,25-28); na verdadeira liberdade de seus membros (Gal 5,1); no compartilhamento desprendido (Mt 19,21) e no amor incondicional daqueles que amam como o Senhor Jesus os amou (Jo 13,34).

\footnotetext{
${ }^{301}$ Cf. BINGEMER, Maria Clara. Cristianismo secularizado: novos desafios. In ANDRADE, Paulo Fernando Carneiro de; BINGEMER, Maria Clara. Secularização e experiência de Deus. Rio de Janeiro: PUC-Rio, 2012, pp. 113-115.

${ }^{302}$ Cf. Ibid., pp. 121-122.

${ }^{303}$ Cf. Ibid., pp. 126-127.

${ }^{304}$ Cf. GONZALÉZ-CARVAJAL, Luis. Evangelizar em um mundo poscristianianio. Santander: Sal Terrae, 1993, pp. 135-137.
} 
Comunidades que vivam assim apregoarão um verdadeiro, radical, contrastante e inspirador testemunho de vida a sociedade em que se encontram inseridos. ${ }^{305}$

Na verdade, na sociedade de hoje, acima de tudo precisamos pregar com a nossa vida. Pois nossa biografia refletirá a sinceridade e a plausibilidade de nossa experiência. Uma vida que narra ou discorre concretamente sobre o valor prático de nossa fé em Deus. Uma teologia esboçada através de nossa vida, explica Maria Clara Bingemer:

A conexão entre a fé e a prática do seguimento de Jesus implica que esse seguimento não pode ser substituído por pura reflexão ou investigação teorética. A teologia é, até certo ponto, obrigada a pensar partindo do seguimento de Jesus, e pode ser chamada de teologia apenas quando tal seguimento define o lugar adequado de reflexão, e também quando a reflexão mesma é a prática do compromisso existencial e do seguimento. ${ }^{306}$

Portanto, revelamos Deus às pessoas através de nossa própria vida. Dizemos que vale a pena esse relacionamento entre o ser humano de hoje e Deus.

\section{4. \\ O Kerygma para a sociedade individualista}

Jürgen Moltmann descreve um individualismo que caminha velozmente na contra mão de uma criativa manifestação existencial de identidade individual em ambientes coletivos, no qual cada pessoa busca a sua liberdade sem se preocupar com as outras; onde muitas vezes, pelo princípio da concorrência, apenas os mais capazes são recompensados e os fracos ficam relegados ao segundo plano; em que as possibilidades de vida se tornam escassas, tornando a vida uma arena na qual todos lutam contra todos, e o indivíduo se vê apaixonado por si mesmo, empenhado numa postura de progresso impositivo. Moltmann assevera ser este um caminho narcísico para o isolamento e a morte social, onde as pessoas se tornam solitárias, furtadas de suas relações para com os outros. Nesse caso, segundo o referido teólogo, o individual passa a ser a perversão do pessoal. O indivíduo é a distorção da pessoa. Logo, para que os homens possam viver como pessoas, torna-se necessário que estes descubram a dignidade divina da

\footnotetext{
${ }^{305}$ Cf. Ibid., pp. 137-138.

${ }^{306}$ BINGEMER, Maria Clara. Cristianismo secularizado. pp. 127-128.
} 
comunhão. Pois, personalidade sempre deverá desembocar em sociabilidade, para que não descambe em um individualismo egoísta. ${ }^{307}$

$\mathrm{Na}$ atualidade, uma das expressões de liberdade consiste do direito de posse do ser humano sobre sua própria pessoa. Homem e mulher usufruem o cultivo da pertença própria e de suas capacidades. Esta auto-demarcação social conduz o ser humano a uma indiferença alienante onde a liberdade pessoal de cada um extingue seu comparecimento participativo a vida do outro. Trata-se de uma sociedade solitária onde não se incomodam uns aos outros, um direito adquirido.

Contudo, antes de ser um indivíduo, um átomo indivisível, a pessoa só se faz ser humano completo em relações sociais de mútua receptividade do tomar e dar, do ouvir e falar, do experimentar e tocar, do reconhecer e ser reconhecido. Assim se constitui um ser humano, nessa economia relacional se faz uma pessoa. Na verdade, a liberdade pessoal é preservada através da vida comunitária, pois a individualização progressiva inibe e atrofia, pois é na abertura da liberalidade predominante na convivência de uma comunidade aberta que se qualificam relações intersubjetivas. Amabilidade, hospitalidade, sociabilidade e generosidade intercambiarão a participação de outras pessoas em nossa vida. Relações intersubjetivas não são ocasionadas tão somente pelo reconhecimento de amizade recíproca, mas também pela certeza de ser reconhecido e estimado, uma consciência que traz consigo um sentimento de liberdade e abertura para a saída de si em oferta ao outro. Neste reconhecimento, não há defesa nem reclusão, o ser humano se abre ao seu próximo e no seu espaço livre e pessoal outros poderão se desenvolver livremente, pois o outro não lhe constitui obstáculo à liberdade pessoal, mas sim seu complemento e possibilidade. Na reciprocidade da vida surge uma comunidade realmente livre. ${ }^{308}$

Por isso Jürgen Moltmann considera fundamental o exercício dialógico da liberdade:

Enquanto liberdade significar domínio, temos que separar tudo, temos que isolar, individualizar e distinguir para podermos dominar. Mas quando a liberdade se chama comunhão nós experimentamos a união de todas as coisas que estavam separadas. A alienação entre homem e homem, a separação entre a sociedade humana e a natureza, a divisão de corpo e alma, e por fim o medo religioso - tudo isso é suprimido, e nós experimentamos libertação quando voltamos a ser uma só

\footnotetext{
${ }^{307}$ Cf. Ibid., p.399

${ }^{308}$ Cf. MOLTMANN, Jürgen. Ética da esperança. pp. 191-193.
} 
coisa uns com os outros, com a natureza e com Deus. Liberdade como comunhão, é, portanto um movimento contrário à corrente da história das lutas pelo poder e das lutas de classes, onde só conseguíamos entender liberdade como domínio. ${ }^{309}$

Uma sociedade não poderá ser considerada verdadeiramente livre se estabelecida tão somente pela liberdade privada de seus indivíduos ou sobre quaisquer possíveis basilares de dominação opressora ${ }^{310}$, mas mediante o exercício de uma liberdade comunicativa e na experiência de justas relações, onde pessoas participam efetivamente das demandas existenciais umas das outras. Nisto consiste o amor e a solidariedade que a verdadeira comunidade cristã necessita apregoar a sociedade em que vive. ${ }^{311}$

Jürgen Moltmann viu nesta relacionalidade, uma tarefa primordial da igreja que agencia a proclamação do reino, ante as demandas da sociedade:

É muito pouco dizer que o reino de Deus só tem que se ocupar da pessoa, pois a justiça e a paz do reino prometido são conceitos relativos e se referem também às relações dos seres humanos entre si e para com o mundo; do contrário, a fé de uma personalidade social é mera abstração. ${ }^{312}$

Portanto a esperança cristã firma-se sobre o anúncio de um reino portador de verdadeira vida e dignidade do ser humano, acompanhado de relações verdadeiramente justas. ${ }^{313}$

O amor de Jesus ultrapassava expressões solidárias de âmbito exclusivamente coletivo. Seu sentimento não se limitava a família privilegiando-a (Mt 10,34-39), nem se permitia demarcar por fronteiras tribais, abrindo-se em diálogo de acolhimento aos samaritanos, descriminados em sua época, e aos

\footnotetext{
${ }^{309}$ MOLTMANN, Jürgen. O Espírito da vida: uma pneumatologia integral. Petrópolis, Rio de Janeiro: Vozes. 2010, p. 118.

${ }^{310}$ Segundo Jürgen Moltmann toda história até agora pode ser vista como um conflito permanente por poder e o aumento de poder próprio de uma pessoa. A única pessoa considerada livre desse conflito é aquela que adquire poder e governa. Os perdedores e subjugados são considerados "não livres”. O autor lembra que uma raiz linguística da palavra liberdade provém da palavra escravocrata: apenas os mestres são livres - não seus escravos, mulheres e crianças. Logo, pessoas que entendem liberdade como dominação podem ser livres apenas às custas das outras, pois sua liberdade significa opressão para outras, sua prosperidade empobrece outras pessoas e seu poder extrai o poder dos mais fracos. Segundo o referido autor o crescente individualismo das pessoas na sociedade moderna contribui para sua nova escravização. "Divida e governe" foi o método romano comprovado de dominação. Quando as pessoas querem governar sobre as outras, elas as separam e isolam, conduzindo-as a parte e individualizando-as. O indivíduo moderno é o produto final do método "divida e governe". Cf. Id. Liberdade e comunidade na era do individualismo e globalização. pp. 20-21.

${ }_{311}$ Cf. Id. Ética da esperança. p. 193.

${ }^{312}$ Id. Teologia da esperança. p. 410.

${ }^{313}$ Cf. Ibid., p. 411
} 
romanos, reconhecidos como opressores do seu povo. Também ainda, não se ateve as barreiras impostas pelo forte condicionamento do sistema religioso de sua época, partindo sempre em busca dos pecadores e excluídos da comunidade religiosa vigente.

Segundo o essencial exemplo de Jesus, antes de reforçar o sentimento coletivo no qual se está imerso, o amor deve em primeiro lugar reconhecer o outro, aquele que é diferente. De forma personalizada, o amor de Jesus situa em primazia o outro, tal qual é, em suas distintivas peculiaridades, aquele que não é de sua família, sua tribo, ou de mesmo idioma, raça, cultura e até religião. Assim, conforme ensinado pelo seu Mestre, mesmo podendo-se encontrar o outro dentro da mesma família, tribo ou igreja, para os primeiros cristãos, o outro do judeu era o pagão, do grego era o bárbaro, do homem era a mulher e do amo era o escravo. Devido às diferenças, constituía-se assim, um grande desafio ao exercício do amor entre seres humanos. Pois é no reconhecimento do outro que o acolhemos existencialmente em seu direito de viver, agir, ocupar seus espaços e progredir em nossa sociedade. Trata-se de um exercício de santo incômodo, um convívio saudável de diferenças, pois amar é servir. ${ }^{314}$

Essa solidariedade caracterizada pela comunhão das diferenças é assim descrita por Jon Sobrino:

É a forma de se relacionarem os cristãos e as igrejas, segundo a conhecida frase paulina: "Suportai-vos mutuamente." É uma concepção e prática da vida cristã à qual é essencial a referência ao "outro", tanto para dar como para receber, tanto no nível humano como no nível eclesial, cristão e teologal, tanto para ver no outro a exigência ética à responsabilidade como para encontrar nesse outro a gratuidade. Portanto, é a forma cristã de superar em princípio o individualismo pessoal ou coletivo, tanto no nível histórico como no nível da fé. ${ }^{315}$

Acima de qualquer dependência estritamente servil, mas na perspectiva de um responsável auxílio efetivamente libertador e compartilhador, o ser humano se doará, abrindo mão de possíveis privilégios e exclusões, demonstrando o mais puro respeito à dignidade da diferença do outro.

Todavia, não se trata apenas de doação, mas também de recepção daquele que o abençoa justamente por sua diferença. Numa dialógica de aceitação e dádiva

\footnotetext{
${ }^{314}$ Cf. COMBLIN, José. Cristãos rumo ao século XXI. p. 86.

${ }^{315}$ PICO, Juan Hernandez; SOBRINO, Jon. Solidários pelo Reino: os cristãos diante da América central. São Paulo: Loyola, 1992, p. 68.
} 
mútua onde os diferentes não se assimilam um no outro, mas se completam em troca relacional, todo progresso se dará antes de tudo, em um ambiente de liberdade. $^{316}$

Entretanto convém lembrar que antes de qualquer sentimento retributivo o desejo de proximidade e amor ao próximo é algo criativo, o nascimento de uma vontade livre e espontânea de libertar-se de toda a inimizade. Não é submissão ou rendição ao ofensor, mas uma sábia superação da inimizade por alguém que vence o próprio instinto de auto-preservação e almejando mais, livra seu ofensor de sua inimizade por meio do amor que atrai os obtusos e alienados em suas crises relacionais a responsabilidade comunitária para com o seu próximo. Tal sentimento empenhado implica num exercício ético responsável que supera as maiores segregações relacionais. ${ }^{317}$

Por outro lado, é justamente na luta contra as forças mortificantes que atuam na sociedade mediante rejeição, isolamento e individualização dos seres humanos que se acolhe e afirma a verdadeira existência. A morte não constitui apenas o fim de uma vida aqui nessa terra, mas também a destruição da vida pessoal, social e natural. Quando o ser humano se encontra enfermo de sua auto-estima passa a padecer de doenças psicossomáticas. Sua mente adoecida compromete o seu corpo e seu isolamento ocasiona por vezes o suicídio. A frieza e a rejeição social acabam por frustrar sua espera por amor.

A fé na ressurreição é a fé na vida que nos motiva ao amor à nossa existência, a almejar viver os sinais da vida futura ainda aqui, pois na esperança da ressurreição também se justifica a opção da humanidade pela vida, já que é na própria ressurreição que podemos perceber o sim do Deus que criou o ser humano para a vida. No cerne do evangelho cristão se encontra a vida, no Cristo que venceu não somente a morte física, mas todos os poderes implicados na anti-vida, trazendo vida em abundância (Jo 10,10). Na verdade, Jesus não ofereceu uma nova religião, antes sim, uma nova proposta existencial, para um novo e comunitário estilo de vida. ${ }^{318}$

\footnotetext{
${ }^{316}$ Cf. COMBLIN, José. Cristãos rumo ao século XXI. p. 87.

${ }^{317}$ Cf. MOLTMANN, Jürgen. O caminho de Jesus Cristo. p. 207.

${ }^{318}$ Cf. Id. Vida, esperança e justiça: um testamento teológico para a América Latina. São Bernardo do Campo, São Paulo: EDITEO, 2008, pp. 64-65.
} 
Dado o fato de que o corpo humano não consiste tão somente de pura exterioridade, assim como o espírito humano não é pura interioridade, o ser humano constitui uma unidade interconectada entre corporeidade e espiritualidade. Portanto, corpo e espírito definem duas dimensões de um único ser humano. ${ }^{319}$ Toda compreensão reducionista na qual o corpo humano seria limitado a um simples organismo vivo, bem como considerado a mera exterioridade ou ainda, um simples instrumento do espírito, fica descartada ante seu fundamental papel em nossa experiência relacional de comunicação com o mundo, os outros seres humanos e com Deus. Na consciência e valorização de sua totalidade, corpo e espírito, o ser humano amadurece em suas relações afetivas, na expressividade comunicativa de suas emoções e sentimentos.

Entretanto, como mencionado no primeiro capítulo dessa pesquisa, junto ascensão e proeminência individualista, a era atual foi acometida de um surto de culto e supervalorização do corpo. Imersa e por vezes perdidas num oceano que perpassa entre outras coisas, modalidades esportivas, exercícios bioenergéticos, uso de cosméticos, cirurgia plásticas e tratamentos para rejuvenescimento, pessoas têm feito do seu corpo um fim em si mesmas, uma distorção desumanizante, fomentada por uma pesada publicidade que escolta essa temática.

Na verdade, o cuidado e a preocupação com o corpo sempre deverá estar a serviço de um projeto pessoal de vida integralizado multiplicidade de emoções que é o ser humano. ${ }^{320}$ A medicina psicossomática descarta toda compreensão reducionista do corpo humano, acentuando a pessoa como uma unidade psicossomática, onde a alma é influenciada pelo corpo, e por sua vez, também opera nele. Assim, toda doença constitui um fator degenerativo não somente aos órgãos do corpo, mas também a toda a pessoa em sua integralidade. Quando examina o paciente, o médico não se depara apenas com um corpo doente, mas sim com toda a pessoa enferma. ${ }^{321}$ Uma acentuação unilateral aos valores corpóreos ou espirituais em detrimento um do outro sempre ocasiona pobreza e mutilação do exercício existencial de humanização. ${ }^{322}$

\footnotetext{
${ }^{319}$ Cf. RUBIO, Alfonso Garcia. Unidade na pluralidade: o ser humano à luz da fé e da reflexão cristãs. São Paulo: Paulus, 2001, p. 464.

${ }^{320}$ Cf. RUBIO, Alfonso Garcia. Evangelização e maturidade afetiva. pp. 100-101.

${ }^{321}$ Cf. MOLTMANN, Jürgen. No fim, o início: breve tratado sobre a esperança. São Paulo: Loyola. 2007, p. 77.

${ }^{322}$ Cf. RUBIO, Alfonso Garcia. Evangelização e maturidade afetiva. p. 101.
} 
Por isso Alfonso Garcia Rubio declara:

É mister cuidar do corpo com sua expressividade, mas sempre em função do projeto de humanização, em articulação com o conjunto de dimensões que fazem parte da pessoa. Articulação, mas especificamente entre corporeidade e espiritualidade, no interior da unidade da pessoa. Algo que não pode ser realizado sem tensões e sem certa disciplina interior. ${ }^{323}$

Por outro lado, de fato, esse corpo degenera aqui em vida, pois a morte ameaça todo ser vivente. Todavia, embora degeneração e morte seja uma parte integrante da vida, segundo a fé cristã, nunca se poderá haver harmonia entre a vida e a morte sem uma real esperança de ressurreição. Por isso faz-se necessário apregoar a dinâmica verdade do significado restaurador da ressurreição de Cristo para o ser humano. O amor diz sim a vida e o corpo almeja a ressurreição. Aqui nessa vida, o ser humano se expõe ao processo degenerativo comum: doenças, envelhecimento, sofrimentos, tristezas e até a morte. Mas é justamente a esperança de que tudo se redundará no cumprimento de um plano regenerador divino, que fará nascer no coração desse ser humano um sabor especial para a aposta da vida e o merecido amor à mesma. Enfrentando corajosamente todo o processo restaurador e na força da ressurreição de Cristo que já atua aqui nessa existência, ele será impulsionado ao amor à vida e aos seus irmãos (Jo 3,14).

$\mathrm{Na}$ verdade, sob a perspectiva da história humana a ressurreição de Cristo dentre os mortos fez iniciar a nossa ressurreição. A morte foi destruída e seu poder antidivino foi expulso da criação, uma redenção de proporções cósmicas já se iniciou. O corpo marcado muitas vezes por obsessivas tentativas de reparos estéticos alternativos já começou a ser restaurado. Se a morte atua nessa vida pela violência da separação, a ressurreição se faz pelo poder do Espírito da reunificação, anulando os terríveis efeitos da morte. A ressurreição restaurará dinâmicas relacionais rompidas pela morte entre seres humanos e também entre corpo e alma, onde esta, eleva-se do corpo, distanciando-se de suas necessidades e imperfeições.

No aguardo da ressurreição dos mortos e da renovação de todas as coisas, e pelo poder do Espírito que ressuscitou o Senhor Jesus Cristo, renasce no ser humano pelas forças do mundo vindouro, uma esperança viva, de uma

\footnotetext{
${ }^{323}$ Ibid., p. 102.
} 
ressurreição que compreende um ser humano saudável, completo e integral, à semelhança do Deus criador.

Por isso Jürgen Moltmann explica:

A esperança na "ressurreição da carne", pelo contrário, nos conduz a experimentar o corpo bem de outro modo. Não somente a sua alma, mas o homem todo, corpo e alma, é semelhante a Deus, pois "ele os criou homem e mulher, segundo a sua imagem", ... Por isso, não só a alma, mas também o corpo deve ser "templo do Espírito Santo” - como afirma Paulo, reiteradamente. O "Espírito Santo”, porém é o Espírito da vida. Onde esse Espírito é experimentado na sua atualidade, corpo e alma retornam a unidade, as separações nocivas à vida e os conflitos que anelam a morte são superados. Ao desaparecer o medo da morte, desaparece também a angustia da vida. ${ }^{324}$

Portanto, esse mesmo Espírito possibilita ao ser humano viver, amar e morrer plenamente, na certeza de uma ressurreição que proporcionará ao mesmo a plenitude de sua regeneração total. ${ }^{325}$

\section{5. \\ O Kerygma para a sociedade hedonista}

Na pós-modernidade a experiência de viver intensamente o presente, acabou se tornando o grande ideal de vida ${ }^{326}$, onde os sonhos de vida se tornam sonhos de consumo e os projetos perdem o sentido. As mudanças acabam acontecendo mais rapidamente do que se possa acompanhar, perdendo-se com isso o sentido de processo e o senso de história. ${ }^{327}$

Na verdade, nossa compreensão de vitalidade deve distanciar-se do espírito hedonista instalado desde as sociedades modernas, nunca devendo ser confundida com o culto a saúde, ao corpo ou a qualquer eficiência produzida por uma força vital. Para Moltmann, a verdadeira vitalidade surge no amor à vida, o que se opõe

\footnotetext{
${ }^{324}$ MOLTMANN, Jürgen. Quem é Jesus para nós, hoje? Petrópolis, Rio de Janeiro: Vozes, 1996. pp. 87-88.

${ }^{325}$ Cf. Ibid., p.89.

${ }^{326}$ Na pós-modernidade o ser humano procura viver sem dor e sofrimentos. Temas como: saúde perfeita, corpo saudável, transplantes, plásticas, criogenia, engenharia genética e promessa da vida eterna, tem cobrado da medicina caminhos de solução e comparecimento constante à questão do bem estar e preservação humana. Assim, a sociedade tem adoecido, vítima de uma espécie de hipocondria. Uma crescente demanda psicanalítica e pastoral avança por conta de um ser humano que deseja livrar-se a todo custo do sentimento de culpa. Uma sociedade intensa, que protagoniza um papel profundamente utilitarista, empenhada em transformar todas as coisas em objetos para atender as suas demandas existenciais. Cf. DURKHEIM, Émile. Sociologia e filosofia São Paulo: Ícone, 1994, p.105.

${ }^{327}$ Cf. MOLTMANN, Jürgen. Experiências de reflexão teológica. p. 45.
} 
diretamente a qualquer processo que tenha por finalidade nos entorpecer em nossas rotinas. ${ }^{328}$

Faz-se necessário que os seres humanos abandonem sua dependência do princípio de prazer que se manifesta fundamentalmente através do predomínio de suas vontades, para abraçarem de forma madura a realidade. Pois quando em sua busca pelo prazer, o ser humano caminha em direção à realidade, ele amadurece. ${ }^{329}$

Longe de qualquer conceituação alienante que tente transferir novas perspectivas de vida propostas pelo Reino de Deus para um mundo distante, nossa experiência de fé deve ser vivida na realidade. A vivência dessa realidade é boa oportunidade para o desenvolvimento de uma expressão religiosa quando é alimentada pelos desejos e esperanças humanas de salvação.

É preciso também considerar que a resignação a uma realidade que é caracterizada muitas vezes, por esperanças insatisfeitas, poderá não somente conduzir o homem do princípio de prazer ao princípio da realidade da vida, mas também levá-lo a uma atitude de contentamento apático, um desalojamento próprio de seus desejos por felicidade e conquistas futuras. Entretanto, suas aspirações podem amadurecer na sensibilidade e abertura às demandas existenciais de seu próximo, pois os sonhos de sua vida constituem lugar fecundo para a elaboração e exercício humanizador de alteridade. Quando os sonhos se atêm à infantilidade de desejos alienados o ser humano adoece mergulhando em neuroses. $^{330}$

Jürgen Moltmann descreve uma quadro sintomático de enfermidade caracterizado basicamente pela fuga e apatia da realidade:

Há formas psicológicas e religiosas da humanidade oprimida, obstruída, doente e caminhando para a morte. Sua característica básica parece ser a apatia. Há situações da humanidade doente e oprimida, e o elemento da doença e da opressão é expresso nessas formações de padrões específicos, que pretendem proteger a vida das enfermidades e opressões. ${ }^{331}$

\footnotetext{
${ }^{328}$ Cf. MOLTMANN, Jürgen. O Espírito da vida. pp. 89-90.

${ }^{329}$ Cf. MOLTMANN, Jürgen. O Deus crucificado. pp. 379- 383.

${ }^{330}$ Cf. Ibid., pp. 379- 383.

${ }^{331}$ Ibid., p. 385.
} 
Assim, uma espécie de autoproteção excessiva e nociva a saúde emocional adoece o ser humano que busca inutilmente alienar-se da vida que o cerca com todo o seu contexto desafiador.

A tentativa do ser humano de alimentar apenas suas expectativas e necessidades presentes, esquecendo-se de que sua existência constitui um todo, com toda a sua história de vida, acaba por empobrecer o sentido de sua realidade presente. Pois é na integralidade de sua história, passado e presente, que o mesmo se abre a revisão e ao progressivo desenvolvimento de seus desejos. Ele progride no pathos do Deus crucificado e em abertura sympathetica consciente e responsável, se faz presente à vida que o cerca.

A esperança da fé cristã nunca poderá ser reduzida a qualquer espécie de fuga utópica de quem fixa seu olhar no futuro tentando negar a realidade em que se encontra inserido, ao invés de encarar os sofrimentos presentes da vida cotidiana de sua sociedade. Antes de tudo, os símbolos de nossa esperança devem ser diferenciados de ideais e perspectivas idólatras que apregoam a mensagem do medo ao sofrimento e da recusa da cruz. ${ }^{332}$

Jürgen Moltmann descreve a fé cristã como uma expressão dinâmica da sensibilidade humana:

Compreende-se a fé cristã como o desenvolvimento de uma humanidade capaz de sofrer e de amar na situação da paixão de Deus, ela será afetada por essa crítica, pois não espalha apatia naquilo que é sempre igual, mas pelo contrário, faz com que a apatia humana se torne supérflua e a destrói em virtude da paixão de Deus; é uma parceira na tentativa de libertar o homem dos deuses e das leis do recalque, do amor próprio, do parricídio e da ilusão. Libertar o homem doente dos seus círculos viciosos psicológicos oferece não somente a racionalidade crítica e o suporte ao ego, que são geralmente invocados contra as estratégias psicológicas do mal, mas também oferece a nova vivacidade espontânea que é necessária a racionalidade crítica, como a atmosfera na qual se pode desenvolver livremente. ${ }^{333}$

Por isso, a esperança humana não se fundamenta em qualquer tipo de alienação ou repugnância pelo presente e suas demandas existenciais, mas na expressiva sensibilidade do amor sofredor e solidário do Crucificado ante a vida em suas perplexidades e complexidades. Também a própria ressurreição, como símbolo central e paradoxal da regeneração humana que caminha para a consumação, mesmo ante a realidade dessa existência, sujeita a morte e ao

\footnotetext{
${ }^{332}$ Cf. Ibid., pp. 383-384.
}

${ }^{333}$ Ibid., pp. 385-386. 
pecado, traz consigo uma esperança firmemente ancorada ao sentido de realidade mais intensivo. ${ }^{334}$

Em 1 Cor 15,26 o apóstolo Paulo afirma que no fim a esperança triunfará sobre a morte, seu último inimigo. A vitória da esperança será consumada pela afirmação da vida sobre a morte. Por isso, uma vitória de implicações essencialmente antropológicas, onde o corpo supera, pelo poder da graça divina, a morte. O teor dessa vitória proclama um singular protesto do poder de Cristo contra todas as mortes injustas e inaceitáveis na história humana. ${ }^{335}$ Essa é a esperança inconformada que denuncia toda a condição incompleta em que se encontra a humanidade. Nisso se fundamenta nossa esperança e busca pela completa e futura plenitude de nossa vida. Nossa esperança cristã é vivida diante de Deus e do mundo no aguardo da restauração de nossa condição criatural. ${ }^{336}$

O incansável anseio humano pela completude recebe de Deus, mediante a fé, a confirmação de que sua vida humana alcançará a plenitude oculta em Jesus Cristo. Assim, o ser humano pode assumir todo o seu presente encontrando paz não somente na alegria, mas também na dor, porque mesmo diante do sofrimento, dor e morte comuns a essa existência, ele vislumbra um maravilhoso futuro pelo cumprimento das promessas de Deus. ${ }^{337}$ Inserido responsavelmente nas demandas dessa vida, o ser humano, harmonizado a sua existência, aguarda a vinda do seu Senhor ressurreto. Seu olhar para o futuro é de esperança e não de fuga, pois ele sabe que sua fé e a esperança plenificam-se no amor a Deus e à humanidade:

\begin{abstract}
Quando começamos a viver na fé e na esperança das possibilidades e promessas desse Deus, abre-se diante de nós toda a plenitude da vida enquanto vida histórica, a qual assim pode ser amada. Somente no horizonte desse Deus se torna possível um amor que é mais do que filia, amor ao existente e ao igual, mais ágape, amor para com o não-existente, amor para com o desigual, com o indigno, sem valor, perdido, transitório e morto; um amor que é capaz de tomar sobre si o que há de aniquilador na dor e na alienação de si mesmo, porque tira sua força de esperança na creatio ex nihilo. Ele não afasta o olhar do não-existente para dizer 'não é nada', mas ele mesmo se torna força mágica que tudo traz à existência. ${ }^{338}$
\end{abstract}

\footnotetext{
${ }^{334}$ Cf. Ibid., p. 384.

${ }^{335}$ Moltmann explica que A fé em Jesus Cristo, objetiva inserir o ser humano em sua realidade presente, para que o mesmo se desenvolva em esperança, gerando-lhe produtiva inquietude e impaciência e não uma acomodação à realidade. Pois a esperança do futuro prometido arde no coração do ser humano que o aguarda, ante todo presente não realizado. Nossa insatisfação é gerada justamente pela força da inextinguível esperança que arde em nós ainda aqui, em nosso convívio com a incompleta realidade da existência atual Cf. MOLTMANN, Jürgen. Teologia da esperança. pp. 36-37.

${ }^{336}$ Ibid.,. p. 41.

${ }^{337}$ Ibid., p. 49.

${ }^{338}$ Ibid., p. 48. Moltmann explica que a esperança cristã obtém sua inspiração na práxis de vida do
} 
Com certeza, toda essa realidade de fé encoraja à livre e consciente atitude de abandono a uma infantil expectativa de fuga quanto ao futuro que não nos faça assumir o passado e o presente com todos seus reais sofrimentos. Em Deus e em sua esperança que arde em nossos corações, optamos por uma postura simpática à vida. Os sonhos e desejos infantis do ser humano e suas aspirações por satisfação própria amadurecerão em amor no pathos de Deus.

Jürgen Moltmann busca salvaguardar a essência dessa maturidade que aperfeiçoa os desejos e esperanças do ser humano rumo ao seu crescimento interior quando afirma:

O esclarecimento não quer dizer cinismo. Maturidade não quer dizer se tornar um realista experiente, resignado ou cínico, que simplesmente sorri compassivamente para a juventude, a sua e a dos outros. O esclarecimento dos desejos e das esperanças leva a desejos e esperanças esclarecidos e conscientes, e não às despedidas dos mesmos. ${ }^{339}$

Portanto o desenvolvimento dessa maturidade não conduz o ser humano à desilusão de seus sonhos ou algum tipo de resignação simplória à vida que o cerca, mas à clarificação e purificação de suas aspirações e desejos aqui, na caminhada de sua existência.

Entretanto precisamos considerar também que as bem aventuranças do sermão do monte anunciam um cristianismo que se assenta sobre uma proposta de felicidade e não somente de sofrimento. Elas demonstram o real caminho da felicidade ao apresentar o seguimento de Jesus, o qual também, por ocasião de sua tentação, rejeitou falsas propostas de satisfação: dinheiro, honra e poder orgulhoso. Assim, Ele proclamou boas novas de plenitude para a vida que se ancora na certeza da existência de um prazer mais sublime e satisfatório. ${ }^{340}$

$\mathrm{Na}$ verdade, a genuína experiência de vida da fé cristã constitui algo atraente, pois o amor do Deus de Jesus Cristo exerce uma profunda atração sobre

homem Jesus, que engajou-se na história de sua época, assumindo responsável e radicalmente seu papel na vida, morte e ressurreição. Portanto o ser humano não deve projetar toda a força de sua esperança em um distante céu imaginário de bem-aventurados, livre dos vales de lágrimas existentes aqui nessa vida, mas deve contemplar na ressurreição de Jesus Cristo, o futuro da própria terra na qual está plantada a sua cruz. Cf. MOLTMANN, Jürgen. Teologia da esperança. p. 35.

${ }^{339}$ MOLTMANN, Jürgen. O Deus crucificado. p. 384.

${ }^{340}$ Cf. LIBÂNIO, J. B. As lógicas da cidade: o impacto sobre a fé e sob o impacto da fé. São Paulo: Loyola, 2002, p. 110. 
os seres humanos. Mais do que a atratividade que toda a existência e a beleza dessa criação possam oferecer, o Criador é o seu "Sol”, e ela tão somente reflete um pouco da sua glória, do seu resplendor. De fato, ninguém tem condições de satisfazer o ser humano como Deus o faz por seu imenso amor e graça. Em épocas de relativismo Ele proporciona, mais do que certezas absolutas, a dignidade da vida humana através de seus valores que nos concedem estabilidade moral e seguro direcionamento a condução de nossa vida, satisfazendo assim as mais profundas necessidades humanas. ${ }^{341}$

Moltmann também menciona uma diferente plenitude qualitativa de vida, oriunda de um novo nascimento, situada em um instante eterno, onde a eternidade toca o tempo anulando sua transitoriedade, um momento de eterna vitalidade, transbordante em prazer manifesto de forma verdadeiramente satisfatória e real em uma alegria transbordante exalada pelo sopro do Espírito da ressurreição, mas que por sua vez, atua diretamente na vida concreta cotidiana do ser humano mesmo ante as suas derrotas e os medos de sua vida, aquilo que ele mesmo denomina de "uma imensa afirmação de vida". Segundo o referido teólogo, a experiência dessa plenitude de vida deve vivenciada aqui nesta existência:

Falamos também de "vida plenificada", de "vida boa", de "vida bem-sucedida", de "vida feliz" ou de "vida plena de sentido"...O potencial da vida humana deve ser realizado de uma maneira que se possa afirmá-lo completamente e estar satisfeito. Desenvolveram-se dois caminhos para levar uma vida plena de sentido: ou pela participação da responsabilidade humana pelo mundo ou pela auto-realização. No entanto, ambas no fundo estão correlacionadas e não podem ser separadas umas das outras, pois o si - mesmo humano faz parte do mundo e o mundo faz parte do si - mesmo humano. Em resumo: A vida humana é vida afirmada, aceita, interessada e plenificada. Deve ser vivida e vivenciada, acolhida e amada. ${ }^{342}$

E esse amor pela vida se dá através do amor de Deus experimentado no seu Espírito. Moltmann fala também de uma profunda paz eficientemente atenuadora aos corações inquietos, um confortante sentimento sereno mesmo ante as maiores dificuldades, algo que em sua essência se solidariza com o Cristo atribulado do Getsemâni e do Calvário, fruto de uma fé despojada, não somente um sossego,

\footnotetext{
${ }^{341}$ Cf. MCGRATH, Alister. Apologética cristã no século XXI. pp. 308-309.

${ }^{342}$ MOLTMANN, Jürgen. Ética da esperança. p. 81.
} 
mais uma concordância harmoniosa com Deus e consigo próprio, uma certeza tranquila, uma acorde da alma. ${ }^{343}$

Portanto, para Moltmann tais experiências, veiculadas ou proporcionadas genuína e exclusivamente pela nossa fé em Deus e no seu enviado, Jesus Cristo, representam a verdadeira e vital qualidade de vida a ser alcançada em nossa existência. Elas constituem a mais sublime satisfação a ser alcançada por qualquer ser humano, a mais prazerosa otimização de nosso ser.

\footnotetext{
${ }^{343}$ MOLTMANN, Jürgen. A fonte da vida: o Espírito Santo e a teologia da vida. Rio de Janeiro, Petrópolis: Vozes, 1998, pp. 36-40.
} 


\section{5}

\section{Conclusão}

A proposta do nosso trabalho objetivou uma atualização do Kerygma bíblico para o mundo hodierno mediante leitura de seu conteúdo sob as lentes teológico-pastorais do teólogo alemão Jürgen Moltmann. Ante a complexidade sócio-existencial pós-moderna percebemos a necessidade uma reflexão contemporanizada sobre as possibilidades de interação entre a mensagem das boas novas proclamada pelo Senhor Jesus Cristo e as demandas enfrentadas pelo ser humano atual no exercício de sua desafiadora arte da vida. Por isso, essa dissertação propôs-se a análise da abordagem kerygmática Moltmanniana visando oferecer uma responsiva contribuição cristã a referida demanda humana, sem jamais pretender esgotar o tema, mas sim, esforçar-se humildemente pelo progresso do Reino de Deus nos dias atuais.

Em um primeiro momento o referido trabalho buscou aprofundar nosso conhecimento sobre o ser humano pós-moderno e sua configuração existencial imersa em um universo complexo.

A partir da leitura do paradigma racionalista e seu consequente declínio na história, podemos compreender os fatores do período moderno que determinaram toda a constelação existencial em que se encontra o ser humano atual, quando a vida pessoal e social foi construída sobre a afirmação do poder da razão e da técnica; do laicismo das instituições e dos valores, onde o sujeito tornou-se o principal protagonista no pensamento e na ação política, o que potencializou a crença em valores como o progresso e o trabalho, bem como ainda, da rejeição à autoridade da tradição dogmática. Entre os efeitos colaterais contabilizados pelo referido momento histórico, assinalamos as guerras e barbáries, que acabaram por confirmar a carência de amadurecimento do pensamento moderno.

A presente pesquisa constatou também que após a segunda metade do século $\mathrm{XX}$, por ocasião da chegada da era da informação, a ascendência do período pós-moderno, trouxe consigo uma incomensurável diversidade manifesta em significativa pluralidade que se expandiu através das atitudes e expressões culturais mais variadas, abrangendo assim veículos de grande visibilidade como a arte, a arquitetura, a literatura, o teatro e o cinema entre tantas outras, o que por si 
só, já denotava um claro questionamento a qualquer pretensão de análise privilegiada que viesse emitir uma verdade absoluta para sua sociedade.

Passamos então a refletir sobre as influências do novo período que ascendia, seus efeitos existenciais e transformações à vida, pensamento e comportamento do ser humano.

Analisando o universo pós-moderno e suas respectivas implicações existências ao ser humano, constatamos a vigência de uma época flutuante, marcada por uma constante incerteza oriunda de uma dominante ambivalência onde espírito pós-moderno questiona o conceito de uma verdade universal descoberta e provada graças aos esforços racionais. Uma realidade onde o intelecto humano não se faz mais o principal aferidor de tudo o que se deve crer, elevando-se assim os olhos para além da razão, abrindo-se às emoções e às intuições, fatores que gozam de grande privilégio atualmente. Um momento que supera a noção simplória de simples ruptura epistemológica com a razão abstrata, onde ascende uma razão ancorada na sensível compreensão da existência humana mediada pela convivência e empatia.

Refletindo sobre a complexidade relacional contida entre sujeito e objeto, observamos que após séculos de luta em busca de sua emancipação como sujeito ante a cristandade, o que alcançou seu ápice no período moderno quando a filosofia empunhou a bandeira do "eu pensante", o ser humano nunca conseguiu erradicar o vazio espiritual da sua alma. Pois na pós-modernidade, a sede humana se encontra aflorada, quando o referido ser humano, na tentativa de se libertar de uma cultura religiosa com leis morais absolutas, opta por uma religiosidade interiorizada, subjetiva e sem culpa, exercendo sua liberdade de escolha através de uma concreta autonomia de variadas opções que avança difusamente a um universo religioso cada vez maior.

Ao descrever o desenvolvimento do individualismo, destacamos a existência atual de uma evolução des-compartimentada em marcha onde o ser humano agora se desprende de suas contenções tradicionais, tais como ordem familiar, ideologias revolucionárias e nacionalistas, controle disciplinar e moral autoritária, a saber, todos os dispositivos coletivos que possam de alguma maneira contrariar o livre exercício de afirmação plena e inteira do seu princípio de individualidade. 
Quando nos debruçamos a estudar o fenômeno hedonista atual, constatamos um ser humano em crise, angustiado, mergulhado numa cultura cotidiana dominada pela mitologia da felicidade privada e seus ideais atuais, onde o prazer da boa alimentação, o prazer sexual e os cuidados com a imagem tentam dar sentido à sua vivência presente, preferível por esse, a um futuro incerto. Ali, percebemos a forte influência opressora gerada por uma cultura de felicidade mediante a imposição de um rigoroso conjunto de normas de auto-domínio e vigilância, onde as imagens do corpo reificado, fetichizado e modelizado aparecem como um ideal a ser atingido, propagado pelas poderosas vozes midiáticas que fornecem suporte as ilusões alimentadas pelo indivíduo em uma corrida sem previsão de chegada e nem garantia de vitória.

Quando abordamos a questão consumista atual, vislumbramos como uma das principais características da atual sociedade de consumo a efemeridade, onde tudo se destina a liquidez, numa recitação diária de transitoriedade universal, onde nada deve ser feito para permanecer, tudo é refugo. Percebemos ainda que nesse tipo de vida fragmentada em episódios e eventos desconectados, a insegurança tornou-se o ponto do desmoronamento existencial e também de como a referida sociedade carece urgentemente de algo que venha a restaurar sua fé em verdadeiros valores estáveis e duráveis.

Num segundo momento, buscamos visualizar o Kerygma bíblico sob a ótica de nosso teólogo, Jürgen Moltmann. Passamos então a considerar as grandes verdades existenciais contidas no caminhar apregoador de boas novas do Deus manifesto em Jesus Cristo. Seu evangelho destronou a Lei de seu caráter objetivo como obstáculo entre Deus e o ser humano, colocando esse novamente em relacionamento direto com Deus. Ante a referida e boa realidade das novas de Jesus, assinalamos a fundamental importância da graça divina, que ultrapassou toda a tentativa de remuneração pura e formal possibilitando ao ser humano um saudável relacionamento pessoal com Deus, pautado em emocionante gratuidade. Assim, o seu Reino inaugurou um programa social baseado num "jubileu” permanente, onde dívidas são perdoadas e a justiça de Deus é restabelecida no meio do povo demonstrando a definitividade e radicalidade do seu reino, um sábado messiânico sem fim.

Refletindo sobre o caráter inclusivista do Kerygma bíblico vivenciado por Jesus Cristo, podemos visualizar com nitidez a essência sócio-agregadora do seu 
Reino messiânico proclamado em sua comensalidade com os excluídos, uma oferta de comunhão salutar, celebração de alegria para todos os povos da terra.

Ante os sistemas opressores da época de Jesus Cristo, e a possibilidade utópica de um futuro distante encontramos resposta esperançosa na antecipação proporcionada pelo evangelho, que já traz em si a irrupção do futuro pela palavra que liberta. Um Reino imediato, ilimitado, infindável, sinalizado por justiça, comunhão e liberdade apregoado pelo nosso Senhor Jesus, cujo alvo situado são os pobres, doentes e desesperançados.

Chamou-nos a atenção a atmosfera de liberdade e criatividade em que o amor divino se manifesta em dádiva. A gratuidade na perspectiva do responso humano, a quem Deus se doa livremente em amor, aguardando um eco de correspondência no ser humano criado a sua imagem. Um amor que se realiza na felicidade e liberdade responsável do outro, que compartilha de si graciosamente. Um amor sensível e dedicadamente solidário.

Quanto à vulnerabilidade, o sofrimento de Deus por sua criação expresso em seu ápice na entrega de seu Filho, maior manifestação de seu amor revelada à humanidade, chamou-nos atenção a radicalidade do investimento divino de amor para com toda a criação. Um Deus que se aproxima radicalmente por sua encarnação na história e sem manipulá-la. Ele sofre e morre em profundo ato de amor e comprometimento com a humanidade carente. Assim, sua encarnação assumiu todas as dores e angústias da humanidade.

Ao considerarmos as implicações envolvidas no pathos divino que demonstra o interesse de Deus por sua criação, seu povo e seu direito, buscamos ressaltar a sublimidade do seu envolvimento afetivo com relação aos eventos, ações e sofrimentos dos seres humanos, algo muito além de emoções humanas irracionais, ali também podemos considerar a influência de seu pathos sobre o ser humano que se abre a Deus em oração e esperança como homo sympatheticos, tornando-se amigo de Deus e abrindo-se ao presente de Deus em comunhão dialogal. Sua unio sympathetica com Deus o leva também a comunhão com a realidade presente de Deus, fazendo-o sofrer e com o sofrimento de Deus, amar com o amor de Deus, esperar com a esperança de Deus. Enfim, uma verdadeira conversão de sentimentos e afeições, algo surpreendente. Assim ele comunga relacionalmente através dos sentimentos de Deus. 
Passando a considerar algumas implicações envolvidas na graciosa solidariedade divina, destacamos os sofrimentos do Cristo encarnado, marco e veículo central de tradução da referida solidariedade, onde Deus se torna solidário com todos os seres humanos e criaturas em quaisquer que sejam os seus sofrimentos humanos. Assim, ele se une solidariamente a nossa cruz, Ele participa das dores e sofrimentos da humanidade assumindo-as em seu próprio corpo. Ele assumiu todo desamparo, solidão, rejeição e morte na cruz, como também, de forma responsável e apaixonada, todas as implicações de sua vida até sua morte de cruz, levando o ser humano a participar de sua vida, sofrimento, morte e ressurreição.

Por último, ao que tange às boas notícias trazidas por Jesus, a "mensagem da vida” em pessoa, coube-nos escrever sobre o poder regenerador do Reino de Deus apregoado por Ele. Aí ressaltamos o novo começo, como expressão que melhor sintetizaria o caráter essencial de sua ressurreição, quando uma nova ordem passou a ser recriada nesse mundo efêmero. Ordem essa, inaugurada pelo poder regenerador do Espírito da vida, onde toda criação caminha para a consumação de uma nova comunhão de paz, quando auto-isolamento e individualizações existenciais serão deixados para trás. Porque Cristo, o "cabeça” dessa nova comunhão trará toda a harmonia da "plenitude da divindade”.

$\mathrm{Na}$ terceira e conclusiva etapa de nossa empreitada, coube-nos o grande desafio de propor algumas contribuições kerygmáticas pastorais às demandas vivenciadas pelo ser humano pós-moderno. Para tal esforçamo-nos a tecer as referidas interações.

Ante a sociedade de consumo atual entendemos que apesar de o evangelho não proporcionar ainda o fim das carestias da vida nesse mundo e nem uma plenitude consumada, pode conduzir os pobres à bem-aventurança da nova dignidade peculiar aos concidadãos do Reino. Independente da capacidade que o ser humano possua em sua sociedade para o consumo, o evangelho apregoa, na plenitude do poder do Espírito aos pobres, o anúncio do imediato e infindável governo de Javé que devolverá a dignidade aos pobres, fazendo-lhes veículo do futuro de Deus, alvo de seu caminho de comunhão e compartilhamento, de bênçãos que transcendem avaliações meritórias ou compensadoras na sociedade em que vivem. Eles são considerados a mensagem viva da graça de Deus. Também precisamos viver a solidariedade mútua que a igreja primitiva nos legou 
como exemplo. Esse deve ser o norte de nossa práxis social solidária, uma Cristoprática de vida que fará ressuscitar os excluídos ao gozo da vida. Por isso, os cristãos precisam reviver a mensagem da alteridade e provisão, a práxis de Jesus Cristo. Portanto, importa proclamar a mensagem de prosperidade do Reino de Deus, aquela que tem como base a realidade do compartilhamento mútuo experimentado pela verdadeira humanização materializada, uma riqueza existencial, pois como mencionado em nossa dissertação, a felicidade de uma vida bem sucedida depende de relações sociais saudáveis, não do excesso de bens materiais.

No que tange ao predominante clima afetivo de subjetividade em nossa sociedade, um desenvolvimento relacional dialógico e afetuoso será um ingrediente indispensável a pastoral kerigmática atual, porque poderá proporcionar um saudável amadurecimento de fé comunitária e pessoal. Tal relacionalidade demonstrará ser a vida cristã algo realmente relevante ao ambiente ao seu redor. Todo o universo ético proposto pelo Senhor Jesus em seu Sermão do Monte baseou-se no discipulado da vida e na comunhão. Por isso, ensino e relacionalidade estão profundamente interconectados. A pastoral do Senhor Jesus aos necessitados marcou suas vidas, sua existência. Sua ortodoxia materializou-se em concreto responso proclamativo ortopráxico. Sua prioridade era a vida, as pessoas e suas demandas. Assim, sua mensagem fascinava as pessoas e os conduzia a um verdadeiro relacionamento com Deus.

Nossa mensagem deve ser um instrumento de reflexão e expressão que estabeleça significativos valores, propósito, missão, paixão, fé e espírito. Devemos apregoar o deslumbre, a fascinação, e a paixão por Deus, sua sublimidade e sua sabedoria. Ansiar por aquele que possui a decodificação de nossa existência e do sentido da nossa vida, reconhecendo que sua sabedoria e sublimidade superam todas as nossas expectativas. Nossa pregação deve resgatar nas pessoas o sabor da experiência com Deus, a paixão desse relacionamento.

Portanto a relacionalidade por seu veículo afetivo e a sabedoria por sua plausibilidade existencial à vida humana hodierna, constituem necessários ingredientes pastorais a proclamação do Kerygma na atualidade.

$\mathrm{Na}$ atual sociedade pós-cristã, onde o sistema social tem conduzido a humanidade e a natureza à degeneração e até a morte, faz-se extremamente necessário que brilhe sobre o ser humano a luz inconfundível do singular ethos do 
discipulado cristão que associa a fé em Cristo a uma ética abrangente a toda vida. Uma plausível alternativa de vida, em contraste com a violenta e injusta proposta existencial apresenta pelos atuais sistemas políticos, sociais e econômicos reinantes que destroem o ser humano e a natureza. Entendemos também que o testemunho de uma pessoa constitui uma importante e poderosa proclamação silenciosa que ao invés de afirmar verdades teóricas, conduz os seres humanos ao seu redor a levantar dentro de si importantes questões de reflexão existencial alimentadas pela conduta da pessoa por eles observada. Percebemos também que o testemunho coletivo prestado pelos cristãos constitui preciosa forma de inspiração e convite a outros para que conheçam nossas comunidades cristãs, que por sua vez devem também oferecer uma radical alternativa de vida. Atualmente, ante a tantos escândalos por parte de determinados grupos que se intitulam cristãos, uma postura genuinamente cristã em relação aos valores humanos gerará esperança e motivação aos que se encontram desesperançados. Na verdade, na sociedade de hoje, acima de tudo precisamos pregar com a nossa vida. Pois nossa biografia refletirá a sinceridade e a plausibilidade de nossa experiência. Uma vida que narra ou discorre concretamente sobre o valor prático de nossa fé em Deus. Uma teologia esboçada através de nossa vida.

Para a hodierna sociedade individualista precisamos apregoar uma esperança cristã firmada sobre a realidade de um Reino que torna possível verdadeira vida e dignidade para o ser humano atual, mas busca materializar tal verdade em um sadio ambiente, onde se desenvolvam relações verdadeiramente justas. O ambiente de comunhão e comensalidade proclamado nas atitudes de Jesus deve ser pautado num amor que antes de tudo reconheça o lugar do outro, respeitando sua diferença. Esse zelo para com as particularidades de nosso próximo demonstra o quanto somos sinceros quando proclamamos a comunhão ensinada por Jesus.

Finalmente, ao ser humano que nos dias atuais vive a paradoxal angustia da busca pela felicidade e prazer, precisamos proclamar o evangelho da coragem e responsabilidade para com a realidade, frutos de um amadurecimento cristão na reflexão sobre a postura do crucificado, pois se faz necessário que os seres humanos abandonem sua dependência do princípio de prazer que se manifesta fundamentalmente através do predomínio de suas vontades, para abraçarem de forma madura a realidade da fé verdadeira ante as demandas desse mundo, uma 
experiência de fé longe de qualquer conceituação alienante que tente transferir novas perspectivas de vida propostas pelo Reino de Deus para um mundo distante. Pois, a vivência de nossa realidade é boa oportunidade para o desenvolvimento de uma expressão religiosa que viva a sua salvação já aqui nessa desafiadora existência. Na verdade, é na integralidade de sua história, passado e presente, que o ser humano se abre a revisão e ao progressivo desenvolvimento de seus desejos. Ele progride no pathos do Deus crucificado e em abertura sympathetica consciente e responsável se faz presente à vida que o cerca.

Portanto, proclamemos a esperança humana que se firma na expressiva sensibilidade do amor sofredor e solidário do Crucificado ante a vida em suas perplexidades e complexidades. Pois também a nossa ressurreição, como símbolo central e paradoxal da regeneração humana que caminha para a consumação, mesmo ante a realidade dessa existência, sujeita a morte e ao pecado, traz consigo uma esperança firmemente ancorada ao sentido de realidade. Assim, o ser humano precisa assumir todo o seu presente encontrando paz não somente na alegria, mas também na dor, porque mesmo diante do sofrimento, dor e morte comuns a essa existência, ele vislumbra um maravilhoso futuro pelo cumprimento das promessas de Deus.

Concluímos esse trabalho nos sentindo mais incomodados do que antes. Um santo incômodo que nos faz refletir quanto a real utilidade dessa empreitada. A saber, a de suscitar dentro de nós a busca por respostas a questões mais profundas e complexas quanto a nossa vivência cristã na sociedade de hoje, um acrisolamento em nosso conceito do que seja uma experiência de vida pautada nos verdadeiros valores do Kerygma anunciado por Jesus Cristo. Assim, nos sentimos inspirados a caminhar um pouco mais rumo a um maior aprofundamento sobre a autenticidade da vida cristã nos dias de hoje. 


\section{Referências Bibliográficas}

ANDRADE, Paulo Fernando Carneiro de; BINGEMER, Maria Clara. Secularização e experiência de Deus. Rio de Janeiro: PUC-Rio, 2012.

BARTH. Wilmar L. O homem pós-moderno, religião e ética. Revista Teocomunicação. Volume 37, nº 155, março de 2007.

BARROS, Thiago Nunes. Desafios da fé e da razão na sociedade pós-moderna. Revista eletrônica Espaço teológico. Maio de 2010. Disponível em: Http://revistas.pucsp.br/index.php/reveleteo. Acesso em: 01 de maio de 2012.

BASTOS, Levy da Costa. Os caminhos da salvação. São Paulo: Fonte Editorial, 2007.

BAUMAN, Zygmunt. A Sociedade individualizada: vidas contadas e histórias vividas. Rio de Janeiro: Zahar, 2008.

. Ética pós-moderna. São Paulo: Paulus, 2003. . Identidade. Rio de Janeiro: Zahar, 2005.

. Modernidade e ambivalência. Rio de Janeiro: Zahar, 1999.

Modernidade Líquida. Rio de Janeiro: Zahar, 2005.

O mal estar da pós-modernidade. Rio de Janeiro: Zahar, 1998.

. Vidas desperdiçadas. Rio de Janeiro: Zahar, 2005.

Vida para consumo. Rio de Janeiro: Zahar, 2009.

BINGEMER, Maria Clara Lucchetti. Faces e interfaces da sacralidade num mundo secularizado. Revista de Teologia e Ciências da Religião, Ano VII, n. 7, dezembro/2008.

Jesus Cristo: servo de Deus e Messias glorioso. São Paulo. Paulinas: Valencia, ESP. Siquem, 2008.

Um rosto para Deus? São Paulo: Paulus, 2005.

CASTIÑEIRA, Ángel. A experiência de Deus na pós-modernidade. Rio de Janeiro, Petrópolis: Vozes, 1997.

COELHO FILHO, Isaltino Gomes. A pós-modernidade, um desafio à pregação do evangelho. Disponível em <http://www.luz.eti.br/es_aposmodernidadeumdesafio. $<$ http://www..html. Acesso e 18 jun. de 2012.>

COMBLIN, José. Cristãos rumo ao século XXI: nova caminhada de libertação. São Paulo: Paulus, 1996. 
DEBORD, Guy. A sociedade do espetáculo. Rio de Janeiro: Contraponto, 1997.

Dicionário Internacional de Teologia do Antigo Testamento. HARRIS, Laird R. (Org.) São Paulo: Vida Nova. 1998.

DUNN, James D. G. Unidade e diversidade no Novo Testamento: um estudo das características dos primórdios do cristianismo. Santo André: Editora Academia Cristã, 2009.

DURKHEIM, Émile. Sociologia e filosofia São Paulo: Ícone, 1994.

FRIDMAN, Luís Carlos. Vertigens pós-modernas: Configurações institucionais contemporâneas. Rio de Janeiro: Relume Dumará/Sinergia/Ediouro, 2009.

GIDENS, Anthony. Mundo em descontrole: o que a globalização está fazendo de nós. Rio de Janeiro: Record, 2002.

GONDIM, Ricardo. Fim de milênio: perigos e desafios da pós-modernidade na igreja. São Paulo: Aba Press, 1999.

GONZÁLEZ-CARVAJAL, Luis. Cristianismo y Secularización: como vivir la fé em una sociedad secularizada. Santander: Sal Terrae, 2003.

.Educar en un mundo postmoderno. Disponível em: http://www.seleccionesdeteologia.net/selecciones/llib/vol32/128/ 128_gonzalez.pdf\%. Acesso em 03 de maio de 2012.

Evangelizar em um mundo poscristianianio. Santander: Sal Terrae, 1993. Ideeas y creencias del hombre actual. Santander: Sal Terrae, 1991.

GOPPELT, Leonhard. Teologia do Novo Testamento. São Paulo: Teológica, 2002.

GRENZ. Stanley J. Pós-Modernismo: um guia para entender a filosofia do nosso tempo. São Paulo: Vida, 2008.

HERVÉ, Juvin; LIPOVETSKY, Gilles. A Globalização ocidental: controvérsia sobre a cultura planetária. São Paulo: Manole, 2012.

HORSLEY, Richard. Jesus e o império: o Reino de Deus e a nova desordem mundial. São Paulo: Paulus, 2004.

JEREMIAS, Joachim. Teologia do Novo Testamento. São Paulo: Editora Teológica, 2004.

LADD, George Eldon. Teologia do Novo Testamento. São Paulo: Hagnos, 2001.

LAPIDE, Pinchas. O sermão da montanha: utopia ou programa? Rio de Janeiro, Petrópolis: Vozes, 1986.

LASCH, Christopher. A cultura do narcisismo. Rio de Janeiro: Imago, 1983. 
LIBÂNIO, João. B. As lógicas da cidade: o impacto sobre a fé e sob o impacto da fé. São Paulo: Loyola, 2002. 2005.

Teologia da revelação a partir da modernidade. São Paulo: Loyola,

LIPOVETSKY, Gilles. A cultura-mundo: resposta a uma sociedade desorientada. São Paulo: Companhia das letras, 2011.

A felicidade paradoxal: ensaio sobre a sociedade de hiper-consumo. São Paulo: Companhia das letras, 2007.

A sociedade pós-moralista. São Paulo: Manole, 2005.

O Império do efêmero: A moda e seu destino nas sociedades modernas. São Paulo: Companhia das letras, 2009.

LOPES, Wilson de Souza. Aos pés de Jesus: O sermão do monte para o $3^{\circ}$ milênio. São Paulo: Cultura cristã, 2001.

MAFFESOLI, Michel. Elogio da razão sensível. Rio de Janeiro, Petrópolis: Vozes, 2005.

O tempo das tribos: O declínio do individualismo nas sociedades de massa. Rio de Janeiro: Forense universitária, 2010.

MARDONES, José Maria. Matar nossos deuses: em que Deus acreditar? São Paulo: Ave Maria, 2009.

MATEOS, Juan. A utopia de Jesus. São Paulo: Paulus, 1994.

MCGRATH, Alister. Apologética cristã no século XXI: Ciência e arte com integridade. São Paulo: Editora Vida, 2008.

MCLAREN, Brian D. A igreja do outro lado. São Paulo: Palavra, 2008.

MIRANDA, Mário de França. A igreja numa sociedade fragmentada: escritos eclesiológicos. São Paulo: Loyola, 2004.

MOINGT, Joseph. O homem que vinha de Deus. São Paulo. Loyola, 2008.

MOLTMANN, Jürgen. A fonte da vida: o Espírito Santo e a teologia da vida. Rio de Janeiro, Petrópolis: Vozes, 1998.

. Ética da esperança. Petrópolis, Rio de Janeiro: Vozes, 2012.

Experiências de reflexão teológica: caminhos e formas da teologia cristã. São Leopoldo: Unisinos, 2004.

Liberdade e comunidade na era do individualismo e globalização. In: KOHL, Manfred W.; BARRO, Antônio Carlos (Org.) A igreja do futuro. Londrina, Paraná: Descoberta, 2011. 

2007.

No fim, o início: breve tratado sobre a esperança. São Paulo: Loyola,

O caminho de Jesus Cristo: cristologia em dimensões messiânicas. São Paulo: Academia cristã, 2009.

O Deus crucificado: a cruz de Cristo como base e crítica da teologia cristã. São Paulo: Academia cristã, 2011.

O Espírito da vida: uma pneumatologia integral. Petrópolis, Rio de Janeiro: Vozes. 2010.

Quem é Jesus para nós, hoje? Petrópolis, Rio de Janeiro: Vozes, 1996.

Trindade e Reino de Deus: uma contribuição para teologia. Petrópolis, Rio de Janeiro: Vozes, 2011.

Vida, esperança e justiça: um testamento teológico para a América Latina. São Bernardo do Campo, São Paulo: EDITEO, 2008.

MOLTMANN, Jürgen; BASTOS, Levy da Costa. O futuro da criação. Rio de Janeiro: Manuad X; Instituto Misteryum, 2011.

MURPHY- O' CONNOR, Jerome. Jesus e Paulo: Vidas paralelas. São Paulo: Paulinas, 2008.

NEUTZLING, Inácio; BINGEMER, Maria Clara; YUNES, Eliana.(Org.) o futuro da autonomia: uma sociedade de indivíduos? Rio de Janeiro, PUC-Rio; São Leopoldo: Unisinos, 2009.

ORTIZ, Renato. Reflexões sobre a pós-modernidade: o exemplo da arquiteura. Disponível em: <http://www.anpocs.org.br/portal/publicacoes/rbcs_ 00_20/rbcs20_10.html> Acesso em: 22 jan. 2013.

PENZO, Giorgio; GIBELLINI, Rosino. Deus na filosofia do século XX. São Paulo: Loyola, 1998.

PICO, Juan Hernandez; SOBRINO, Jon. Solidários pelo Reino: os cristãos diante da América central. São Paulo: Loyola, 1992.

PIKAZA, Xabier. A figura de Jesus: profeta, taumaturgo, rabino e messias. Petrópolis, Rio de Janeiro: Vozes, 1995.

PURIM, Paulo. R. Pós-modernidade e proclamação. Disponível em Http://kerigmaonline.blogspot.com/2006\%2002\%2001arhive.html. Acesso em: 25 de julho de 2011.

QUEIRUGA, Andrés Torres. Um Deus para hoje. São Paulo: Paulus, 1998.

RUBIO, Alfonso Garcia. A caminho da maturidade na experiência de Deus. São Paulo: Paulinas, 2008. 
Evangelização e maturidade afetiva. São Paulo: Paulus, 2006.

O encontro com Jesus Cristo vivo: um ensaio de cristologia para os nossos dias. São Paulo: Paulinas, 2007.

Novos rumos da antropologia teológica. In: RUBIO, A. G..(Org.) O Humano integrado: abordagens de antropologia teológica. Rio de Janeiro: Vozes, 2007.

SALINAS, Daniel; ESCOBAR, Samuel. Pós-modernidade: novos desafios à fé cristã. São Paulo: ABU, 1998.

SANTAELLA, Lúcia. Corpo e comunicação: sintoma da cultura. São Paulo: Paulus, 2004.

Culturas e artes do pós-humano: da cultura das mídias à cibercultura. São Paulo: Paulus, 2003.

SANT’ANNA, Denise Bernuzzi de. Corpos de Passagem: ensaios sobre a subjetividade contemporânea. São Paulo: Estação liberdade, 2001.

SCHILLEBEECKX, Edward. Jesus: a história de um vivente. São Paulo: Paulus, 2008.

SOBRINO, Jon. A fé em Jesus Cristo: ensaio a partir das vítimas. Petrópolis, Rio de Janeiro: Vozes, 2000.

. Cristologia a partir da América Latina. Petrópolis, Rio de Janeiro: Vozes, 1983.

SUNG, Jung Mo. Deus numa economia sem coração. Pobreza e neoliberalismo: um desafio à evangelização. São Paulo: Paulus, 1992.

TAVARES, Sinvaldo S. Teologia da criação: outro olhar: novas possibilidades. Petrópolis, Rio de Janeiro: Vozes, 2010.

TERRA, J. E. M. O Jesus Histórico e o Cristo querigmático. São Paulo: Loyola, 1977. 